A Platinum Open Access Journal for Organic Chemistry

Paper

DOAJ Seal

\title{
Four-directional synthesis of adamantane derivatives
}

Tao Qu, Andrew J. P. White, and Anthony G. M. Barrett*

Department of Chemistry, Imperial College, Molecular Sciences Research Hub, White City Campus, Wood Lane, London, W12 OBZ, England

Email: $\underline{\text { agmb@ic.ac.uk }}$

\section{Dedicated to Professor Horst Kunz on the occasion of his $80^{\text {th }}$ Birthday}

Received 05-04-2020

Accepted 05-30-2020

Published on line $06-11-2020$

\section{Abstract}

1-Adamantanemethanol, 1,3-adamantanedimethanol and 1,3,5,7-adamantanetetramethanol were converted into adamantanes functionalized with one or four $(2 R, 1 S)$-2-formyl-1-cyclopropyl residues using Charette enantioselective cyclopropanation reactions and with one, two or four 4-ethoxy- (or 4-t-butoxy)-3-diazo-2,4dioxobutyl residues from aldehyde and diazo-acetate ester condensation reactions by 1-directional, 2directional or 4-directional syntheses. The synthesis of adamantane fused to cyclopentadiene is also reported.

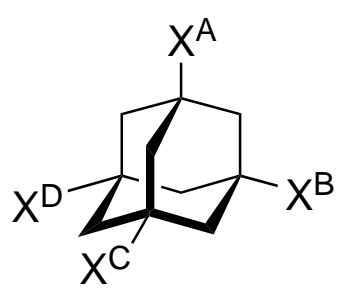

$$
\begin{aligned}
& X^{A}=\underbrace{}_{C H O} ; X^{B}=X^{C}=X^{D}=H \\
& X^{A}=X^{B}=X^{C}=X^{D}= \\
& X^{A}=\mathrm{CH}_{2} C O C\left(=N_{2}\right) C O_{2} R ; X^{B}=X^{C}=X^{D}=H \\
& X^{A}=X^{B}=C_{2} C O C\left(=\mathrm{N}_{2}\right) C_{2} R ; X^{C}=X^{D}=H \\
& X^{A}=X^{B}=X^{C}=X^{D}=C_{2} C O C\left(=N_{2}\right) C_{2} R
\end{aligned}
$$

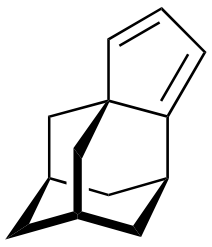

Keywords: Adamantane, 4-directional synthesis, enantioselective cyclopropanation, $\alpha$-diazo- $\beta$-keto-esters 


\section{Introduction}

Fuchs introduced the concept of the Intricacy Quotient (IQ) as a measure of the efficiency of natural product total synthesis. ${ }^{1}$ One of the natural product examples highlighted in this study, was the total synthesis of the CETP inhibitor U-106305 (5) independently by Barrett and Charette. ${ }^{2,3}$ This synthesis was scored at an IQ of 1.83 by Fuchs and the reason for this high value was due to the use of an iterative two-directional synthesis with late stage desymmetrization (Scheme 1) which, for example in the conversion of tercyclopropane $\mathbf{3}$ into quinquecyclopropane $\mathbf{4}$ generated two rings and controlled four stereocenters in an absolute sense. There is an added benefit with two-directional introduction of stereocenters by enantioselective synthesis and that is Horeau amplification of enantioselectivities. ${ }^{4}$ It is clear, based on the Fuchs' analysis, that a total synthesis that depends on a four-directional synthesis is likely to score highly on the Fuchs IQ scale.
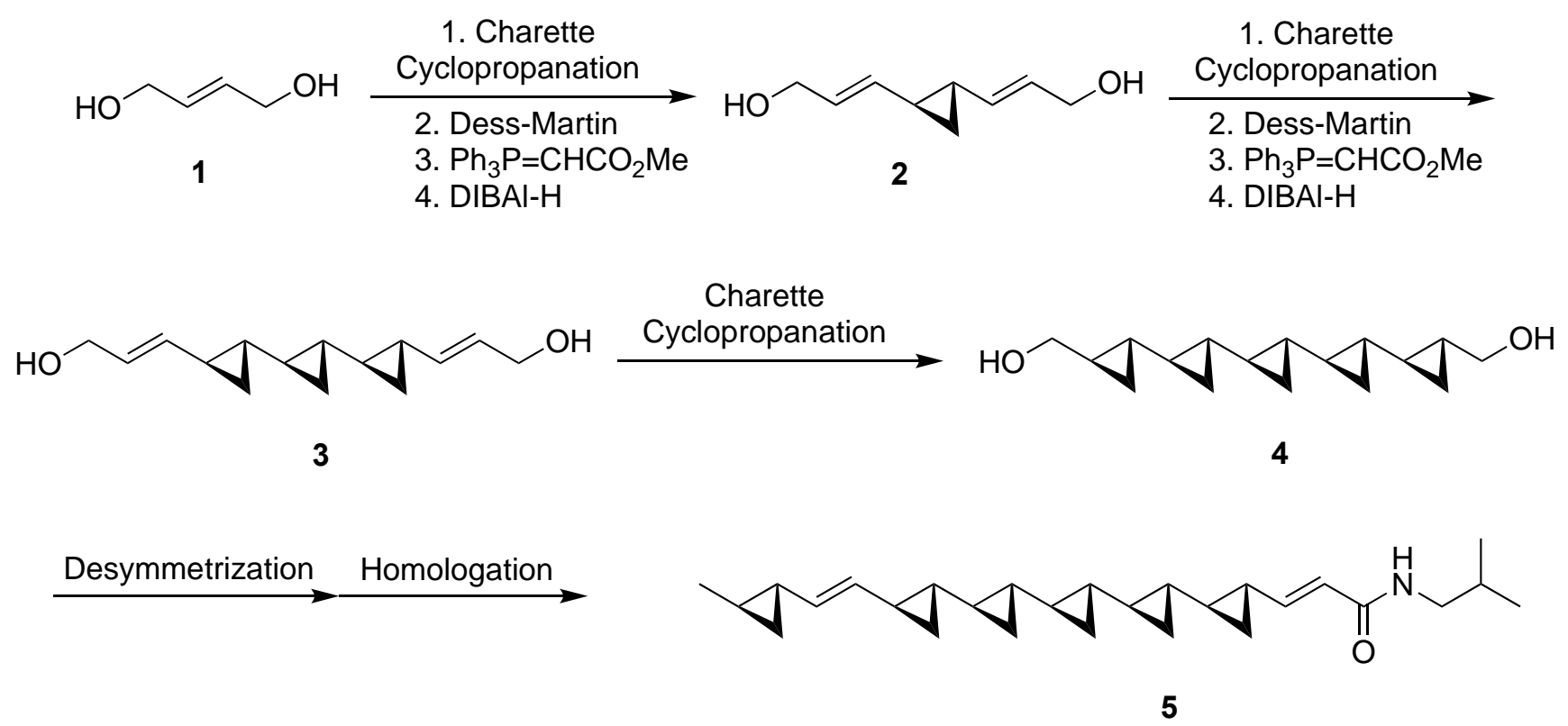

Scheme 1. Barrett and Charette two directional homologation in the total synthesis of U-106305 (5).

Four-directional transformations of adamantanes bearing identical tertiary substituents at $C_{1}, C_{3}, C_{5}$ and $C_{7}$ are well precedented. In a general sense, reaction of the adamantane derivative 6 with various reagents have been used to synthesize other adamantanes 7 bearing four identical substituents $Y$ thereby conserving the symmetry. Most of these known transformations involve the construction of four carbon-heteroatom bonds or the quadruple derivatization of adamantanes functionalized by four identical tertiary aromatic rings. These are illustrated in Table 1 and the paragraph thereafter.

Tetra-aryl adamantanes $6\left(\mathrm{X}=\mathrm{Ph}, 4-\mathrm{AcC}_{6} \mathrm{H}_{4}, 4-\mathrm{O}_{2} \mathrm{NC}_{6} \mathrm{H}_{4}, 4-\mathrm{IC}_{6} \mathrm{H}_{4}\right.$ and 4-ethynyl $\left.\mathrm{C}_{6} \mathrm{H}_{4}\right)$ have been converted into higher molecular weight adamantanes $\mathbf{7}$ by four-directional electrophilic aromatic substitution reactions, enantioselective reductions, aryl iodide to aryl nitrile conversions, nitroarene to aniline reductions, aniline to aryl azide conversions, Suzuki and Sonogashira coupling reactions and 3-component allene, aryl iodide and amine coupling reactions. ${ }^{19-26}$ of particular note in this chemistry are the application of fourdirectional syntheses to construct more complex adamantanes bearing nucleoside and nucleotide side chains $^{21}$ and the Naemura four-directional synthesis of the (+)-[1,3,5,7-tetrakis-trishomocubanylbuta-1,3diynyl]adamantane derivative 10 (Scheme 2). ${ }^{18}$ 
Table 1. General four-directional synthesis of adamantane derivatives

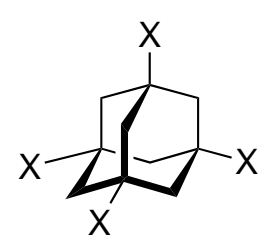

6

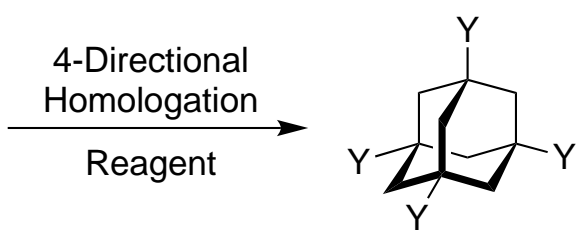

7

\begin{tabular}{|c|c|c|c|}
\hline Reaction & Substituent X & Reagent & Substituent Y \\
\hline Amide Synthesis ${ }^{5-8}$ & $\mathrm{CO}_{2} \mathrm{H}$ or $\mathrm{COCl}$ & $\mathrm{R}^{\prime} \mathrm{R}^{\prime \prime} \mathrm{NH}$ & CONR'R" \\
\hline Dendrimer Amide Synthesis ${ }^{9}$ & $\mathrm{CO}_{2} \mathrm{H}$ or $\mathrm{COCl}$ & $\mathrm{R}^{\prime} \mathrm{R}^{\prime \prime} \mathrm{NH}$ & CONR'R' \\
\hline Ester Synthesis ${ }^{10-13}$ & $\mathrm{COCl}$ & $\mathrm{R}^{\prime} \mathrm{OH}$ or $\mathrm{ArOH}$ & $\mathrm{CO}_{2} \mathrm{R}^{\prime}$ or $\mathrm{CO}_{2} \mathrm{Ar}$ \\
\hline Ester Saponification ${ }^{13,14}$ & $\mathrm{CO}_{2} \mathrm{Me}$ & $\mathrm{KOH}, \mathrm{MeOH}, \mathrm{H}_{2} \mathrm{O}, \mathrm{MeCN}$ & $\mathrm{CO}_{2} \mathrm{H}(90 \%)$ \\
\hline Nitrile Alcoholysis 6 & $\mathrm{CN}$ & $\mathrm{HCl}, \mathrm{MeOH}$ & $\mathrm{CO}_{2} \mathrm{Me}(72 \%)$ \\
\hline Nitrile Reduction ${ }^{15}$ & $\mathrm{CN}$ & $\mathrm{Me}_{2} \mathrm{~S} \cdot \mathrm{BH}_{3}$ & $\mathrm{CH}_{2} \mathrm{NH}_{2}(98 \%)$ \\
\hline Tetrazole Synthesis $^{16}$ & $\mathrm{CN}$ & $\mathrm{NaN}_{3}, \mathrm{ZnCl}_{2}, \mathrm{DMF}, \Delta$ & 5-Tetrazolyl (54\%) \\
\hline Arene Oxidative Degradation ${ }^{13}$ & $\mathrm{Ph}$ & $\begin{array}{l}\mathrm{RuCl}_{3}, \mathrm{NaIO}_{4}, \mathrm{CCl}_{4}, \mathrm{H}_{2} \mathrm{O} ; \\
\mathrm{SOCl}_{2} ; \mathrm{MeOH}\end{array}$ & $\mathrm{CO}_{2} \mathrm{Me}(35 \%)$ \\
\hline Alcohol Swern Oxidation ${ }^{17}$ & $\mathrm{CH}_{2} \mathrm{OH}$ & $\begin{array}{l}(\mathrm{COCl})_{2}, \mathrm{DMSO}, \mathrm{Et}_{3} \mathrm{~N}, \\
\mathrm{CH}_{2} \mathrm{Cl}_{2}\end{array}$ & $\mathrm{CHO}(55 \%)$ \\
\hline 4-Toluenesulfonylation ${ }^{18}$ & $\mathrm{CH}_{2} \mathrm{OH}$ & TsCl, pyridine & $\mathrm{CH}_{2} \mathrm{OTs}$ \\
\hline Cyanide Displacement ${ }^{18}$ & $\mathrm{CH}_{2} \mathrm{OTs}$ & $\mathrm{NaCN}, \mathrm{DMF}, \Delta$ & $\mathrm{CH}_{2} \mathrm{CN}$ (77\% from tetraol) \\
\hline Cyanide Hydrolysis ${ }^{18}$ & $\mathrm{CH}_{2} \mathrm{CN}$ & $\mathrm{H}_{2} \mathrm{SO}_{4}, \mathrm{H}_{2} \mathrm{O}, 120-130{ }^{\circ} \mathrm{C}$ & $\mathrm{CH}_{2} \mathrm{CO}_{2} \mathrm{H}(88 \%)$ \\
\hline Amide Synthesis ${ }^{18}$ & $\mathrm{CH}_{2} \mathrm{CO}_{2} \mathrm{H}$ & $\mathrm{SOCl}_{2}, \Delta ; \mathrm{PhH}, \mathrm{Me}_{2} \mathrm{~N}$ & $\mathrm{CH}_{2} \mathrm{CONMe}_{2}(93 \%)$ \\
\hline Amide Reduction ${ }^{18}$ & $\mathrm{CH}_{2} \mathrm{CONMe}_{2}$ & $\mathrm{LiAlH}_{4}, \mathrm{THF}, \Delta$ & $\mathrm{CH}_{2} \mathrm{CH}_{2} \mathrm{NMe}_{2}(84 \%)$ \\
\hline Tertiary Amine Oxidation ${ }^{18}$ & $\mathrm{CH}_{2} \mathrm{CH}_{2} \mathrm{NMe}_{2}$ & $\mathrm{H}_{2} \mathrm{O}_{2}, \mathrm{MeOH}, \mathrm{H}_{2} \mathrm{O}$ & $\mathrm{CH}_{2} \mathrm{CH}_{2} \mathrm{~N}(\mathrm{O}) \mathrm{Me}_{2}$ \\
\hline Cope Elimination ${ }^{18}$ & $\mathrm{CH}_{2} \mathrm{CH}_{2} \mathrm{~N}(\mathrm{O}) \mathrm{Me}_{2}$ & $160-170{ }^{\circ} \mathrm{C}$ & $\begin{array}{l}\mathrm{CH}=\mathrm{CH}_{2} \text { (79\% from } \\
\text { tetraamine) }\end{array}$ \\
\hline Alkene Bromination ${ }^{18}$ & $\mathrm{CH}=\mathrm{CH}_{2}$ & $\mathrm{Br}_{2}, \mathrm{CCl} 4$ & $\mathrm{CH}(\mathrm{Br}) \mathrm{CH}_{2} \mathrm{Br}(80 \%)$ \\
\hline Acetylene Synthesis ${ }^{18}$ & $\mathrm{CH}(\mathrm{Br}) \mathrm{CH}_{2} \mathrm{Br}$ & $\begin{array}{l}\mathrm{KOH} \text {, triglyme, } 160{ }^{\circ} \mathrm{C}, 30 \\
\mathrm{~mm}\end{array}$ & $\mathrm{C} \equiv \mathrm{CH}=\mathbf{9}(18 \%)$ \\
\hline
\end{tabular}




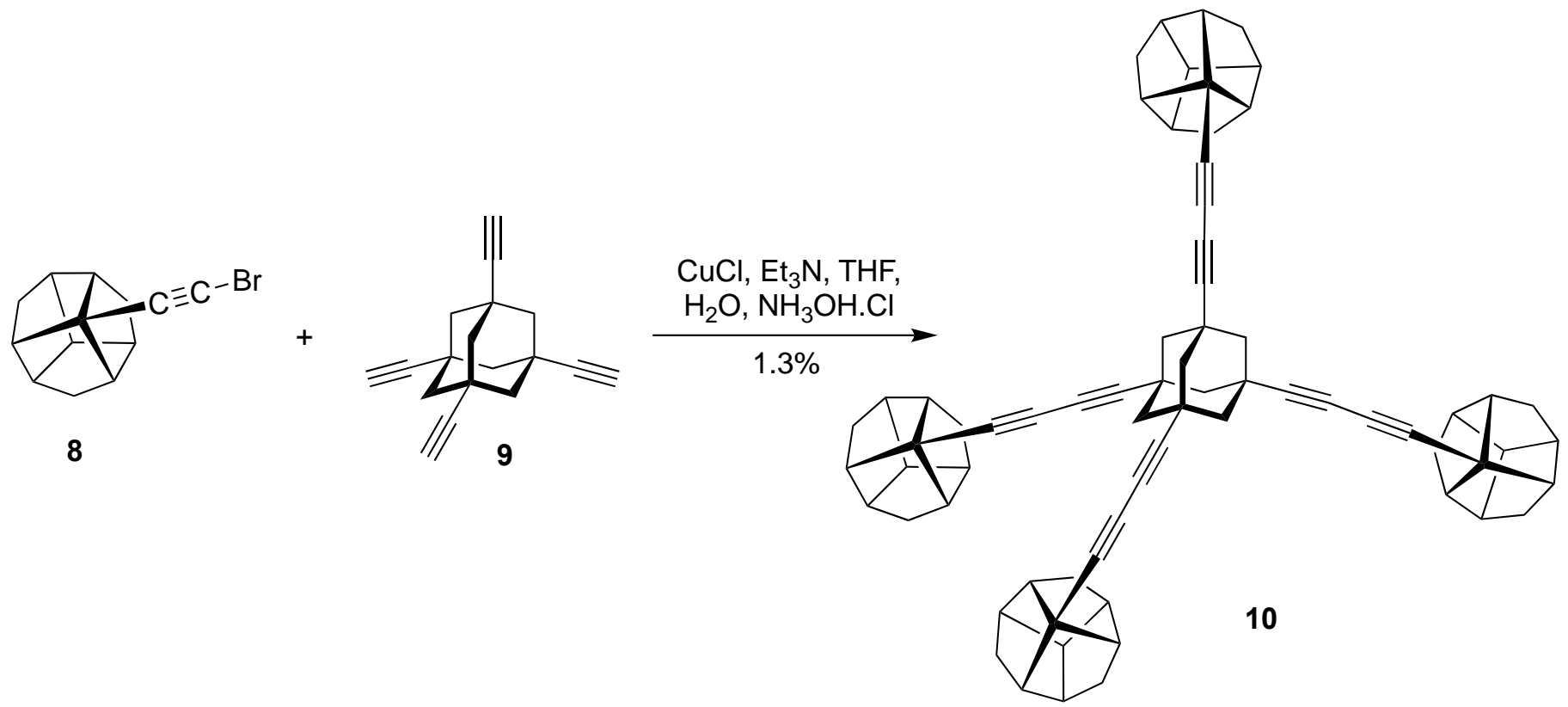

Scheme 2. Naemura four-directional synthesis of the adamantane derivative 10.

There are fewer examples known for four-directional conversion of adamantanes 6 into adamantanes 7 by carbon-carbon bond construction at $\mathrm{sp}^{3}$ centers. These are illustrated in Table 2. The de Meijere conversion of tetra-alkene 11 to tetracyclopropyl-adamantane 12 (91\%) using diazomethane with a palladium catalyst (Scheme 3 ) is particularly relevant to this work. ${ }^{17}$

Table 2. Four-directional synthesis by carbon-carbon construction or change at $\mathrm{sp}^{3}$ centers

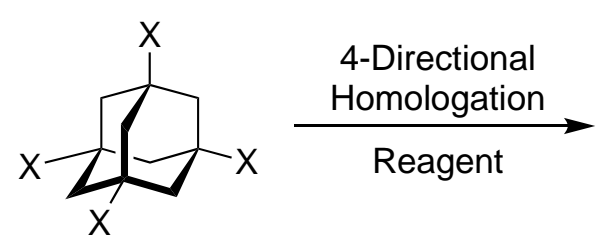

6

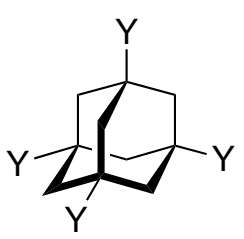

7

\begin{tabular}{|c|c|c|c|}
\hline Reaction & Substituent X & Reagent & Substituent Y (\%) \\
\hline Bromide Photosubstitution $^{6}$ & $\mathrm{Br}$ & hv, NaCN, DMSO & $\mathrm{CN}(73 \%)$ \\
\hline Wittig Reaction ${ }^{17}$ & $\mathrm{CHO}$ & $\mathrm{Ph}_{3} \mathrm{P}=\mathrm{CH}_{2}$ & $\mathrm{CH}=\mathrm{CH}_{2}(82 \%)$ \\
\hline Friedel Crafts Acylation ${ }^{5}$ & $\mathrm{COCl}$ & $\mathrm{PhH}, \mathrm{AlBr}_{3}$ & COPh (42\%), \\
\hline Friedel Crafts Alkylation ${ }^{5}$ & $\mathrm{Br}$ & $\mathrm{PhH}, \mathrm{AlBr}_{3}$ & $\mathrm{Ph}(77 \%)$ \\
\hline Friedel Crafts Alkylation 27 & $\mathrm{OH}$ & $\mathrm{MeOC}_{6} \mathrm{H}_{5}, \mathrm{TsOH}$ & $4-\mathrm{MeOC}_{6} \mathrm{H}_{5}(68 \%)$ \\
\hline Arene Oxidative Degradation ${ }^{27}$ & 4- $\mathrm{MeOC}_{6} \mathrm{H}_{5}$ & $\mathrm{RuCl}_{3}, \mathrm{H}_{5} \mathrm{IO}_{6} ; \mathrm{SOCl}_{2} ; \mathrm{MeOH}$ & $\mathrm{CO}_{2} \mathrm{Me}(42 \%)$ \\
\hline Tertiary Alcohol Synthesis ${ }^{28}$ & $\mathrm{CO}_{2} \mathrm{Me}$ & $\mathrm{PhLi}, \mathrm{Et}_{2} \mathrm{O}, 0{ }^{\circ} \mathrm{C}$ & $\mathrm{C}(\mathrm{OH}) \mathrm{Ph}_{2}(78 \%)$ \\
\hline
\end{tabular}




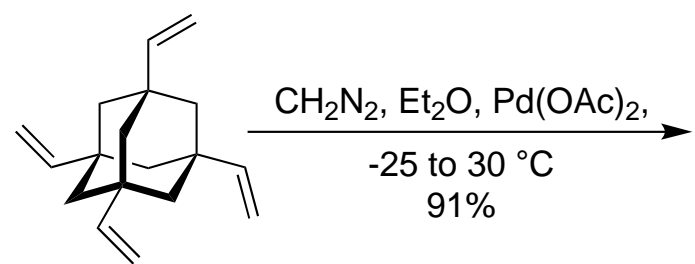

11

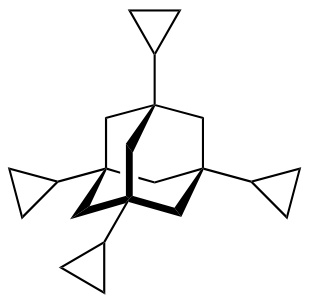

12

Scheme 3. de Meijere four-directional synthesis of tetracyclopropyl-adamantane 12.

In this paper, four directional syntheses of the chiral tetra-cyclopropyl-tetra-aldehyde 14 and the tetra$\beta$-keto-esters 15 from 1,3,5,7-tetra-hydroxymethyl-adamantane (13) are described (Scheme 4). In addition, the conversion of tetra-aldehyde 14 into the derived tetra-4-toluenesulfonylhydrazone and tetra- $\beta$-keto-esters 15 into the derived tetra- $\alpha$-diazo- $\beta$-keto-esters as potential carbene precursors are outlined. Related transformations of adamantanes bearing one cyclopropane-carboxaldehyde residue and one and two $\alpha$-diazo$\beta$-keto-ester residues are described. Such studies may be relevant to the synthesis of diamondoid hydrocarbons. ${ }^{29}$

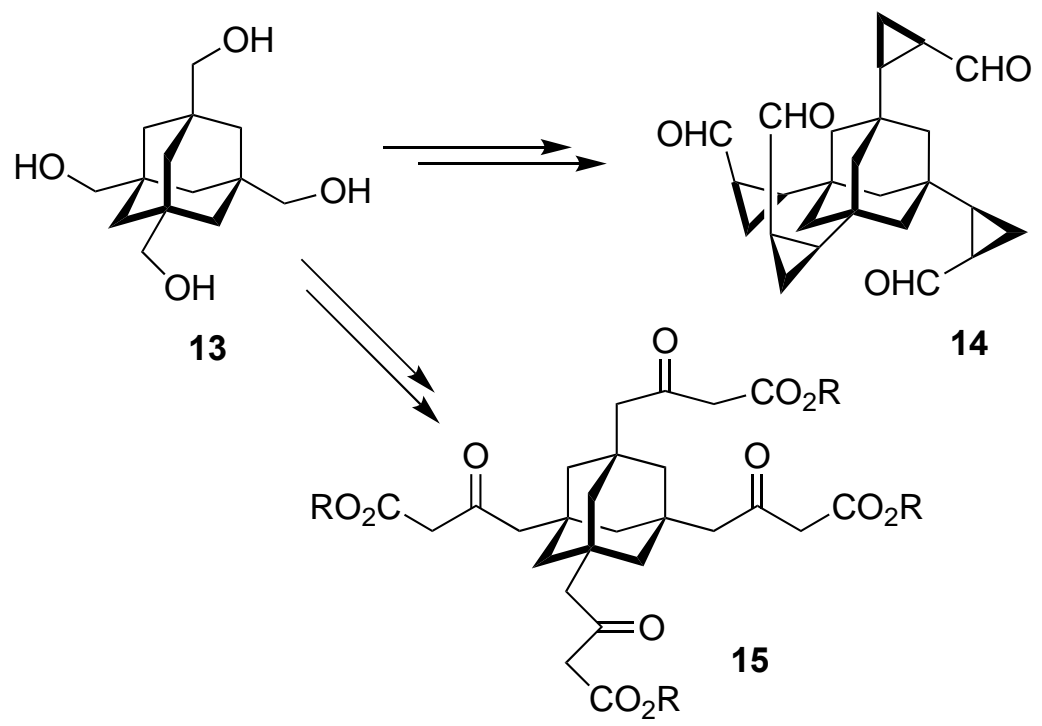

Scheme 4. Conversion of tetraol 13 into tetra-aldehyde 14 and tetra- $\beta$-keto-ester $\mathbf{1 5}$ (this work).

\section{Results and Discussion}

\section{Four-directional homologation of 1,3,5,7-adamantanetetracarboxylic acid derivatives}

Tetramethyl 1,3,5,7-adamantanetetracarboxylate (18) was synthesized from 1,3-adamantanedicarboxylic acid (16) by a modification of Bashir-Hashemi and Li's method. ${ }^{30}$ Since dicarboxylic acid 16 is of low solubility in oxalyl chloride, the dicarboxylic acid 16 was first converted into the more soluble dichloride $17^{31}$ with thionyl chloride. This was dissolved in oxalyl chloride and irradiated at $20{ }^{\circ} \mathrm{C}$ using a medium pressure mercury-vapor lamp (450 Watts) in a quartz vessel to provide, on methanolysis, the tetra-ester 18 in variable yield (25\% on a $10 \mathrm{~g}$ scale to $43 \%$ on a $2 \mathrm{~g}$ scale) depending on the efficiency of irradiation decreasing with scale. Reduction of 
tetra-ester 18 using lithium aluminum hydride gave the corresponding tetraol 13 (91\%). Attempted oxidation of the tetraol 13 to the corresponding tetra-aldehyde 19 was complicated due to its poor solubility in nonpolar solvents. Nonetheless it was soluble in solvents such as $\mathrm{MeOH}$, THF or DMSO. Dess-Martin oxidation of tetraol 13 (50 mg scale) in a mixed-solvent system (dichloromethane/DMSO, 2:1), which was necessary to dissolve the substrate, gave tetra-aldehyde 19 (45\%, $40 \mathrm{mg}$ scale) but this yield was not reproductible on a larger scale $(32 \%, 80 \mathrm{mg}$ scale). Swern oxidation of tetraol 13 in the same mixed-solvent system (dichloromethane/DMSO) ${ }^{17}$ gave tetra-aldehyde 19 in a significantly better yield (70\%, $1 \mathrm{~g}$ scale).

(Z)-Selective Horner-Emmons reaction of tetra-aldehyde 19 under Still-Gennari conditions ${ }^{32}$ at $-78{ }^{\circ} \mathrm{C}$ provided an inseparable mixture of the desired product $\mathbf{2 0}$ and the incomplete olefination products, however reaction at $-20{ }^{\circ} \mathrm{C}$ gave the tetra-alkene 20 as the sole product in $64 \%$ yield. From ${ }^{1} \mathrm{H}$ NMR spectroscopy, the coupling constant between two olefinic protons was $J 13.1 \mathrm{~Hz}$, which is consistent with all four alkenes possessing the cis geometry. ${ }^{33}$ Finally, DIBAI-H reduction of tetra-ester $\mathbf{2 0}$ gave the tetra-(Z)-allylic alcohol $\mathbf{2 1}$ in excellent yield (98\%) (Scheme 5). The cis-geometry and constitution were unambiguously confirmed by a single crystal X-ray structure determination (see Supplementary Material: Appendix-1).

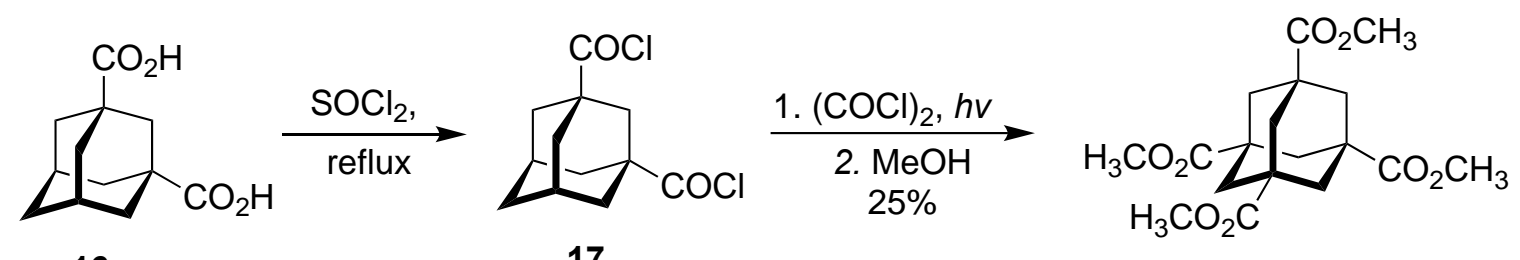

16

17

18

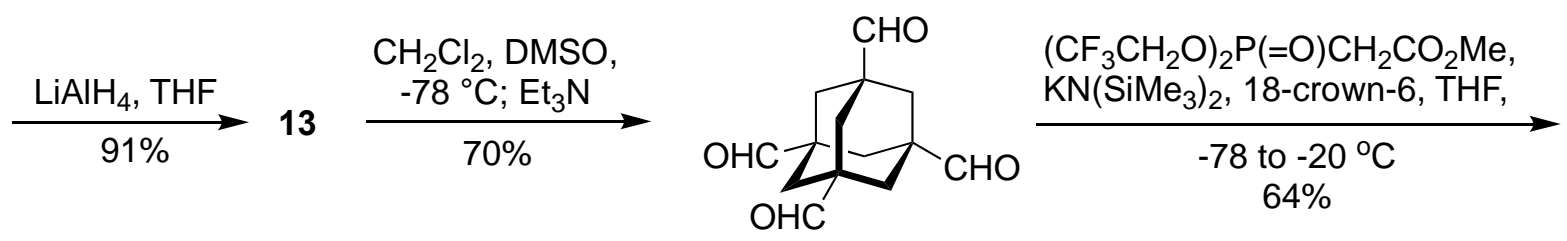

19

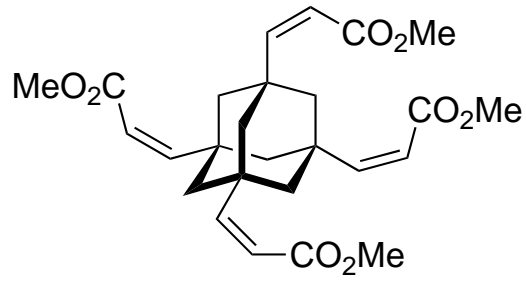

20

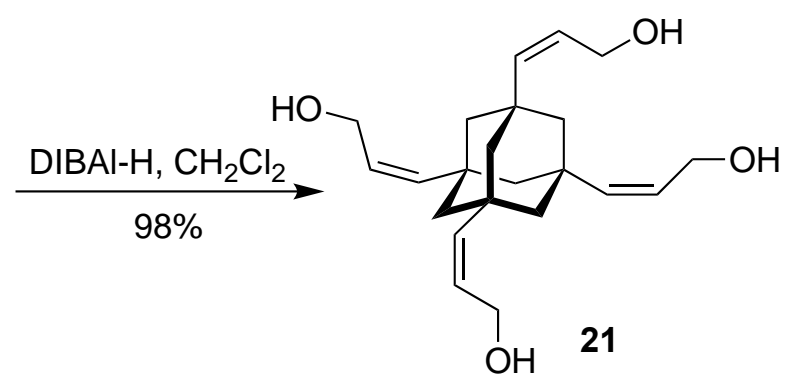

Scheme 5. Synthesis of tetraol 21 using photochemical substitution and (Z)-selective Horner-Emmons reaction.

The tetra-(Z)-allylic alcohol $\mathbf{2 1}$ was of low solubility and this caused significant problems in attempted tetra-cyclopropanation reactions. Prolonged reactions using samarium amalgam or samarium(II) iodide with diiodomethane or chloroiodomethane ${ }^{34}$ failed to provide any identifiable cyclopropanated products. Additionally, the tetra-(Z)-allylic alcohol $\mathbf{2 1}$ was recovered unchanged on attempted tetra-cyclopropanation using the Charette's procedure. ${ }^{35}$ Although, in this reaction, the tetra-(Z)-allylic alcohol $\mathbf{2 1}$ has very low solubility in the solvent $\mathrm{CH}_{2} \mathrm{Cl}_{2}$, it was anticipated that the intermediate zinc-alkoxide species formed from $\mathrm{Zn}\left(\mathrm{CH}_{2} \mathrm{I}\right)_{2}$ and tetraol $\mathbf{2 1}$ would result in desymmetrization and enhanced solubility. This proved incorrect and the Charette reaction gave only unreacted starting material. Attempted transient desymmetrization of tetra- 
(Z)-allylic alcohol 21 by alkoxide exchange using trimethyl borate and subsequent Charette reaction also gave unreacted tetraol 21.

Since direct cyclopropanation of tetra-cis-alkene $\mathbf{2 1}$ had failed to produce any desired tetra-cyclopropane, the corresponding reactions with allylic alcohol $\mathbf{2 5}$ were examined to underscore that the failure in the tetracyclopropanation reaction was solely due to poor solubility. Thus, Swern oxidation of commercially available 1-adamantanemethanol (22) gave rise to aldehyde 23 (82\%). This product 23 was subject to the (Z)-selective Horner-Emmons olefination of aldehyde $\mathbf{2 3}$ under Still-Gennari conditions, ${ }^{32}$ which provided the desired cis-olefin $\mathbf{2 4}$ in low but unoptimized yield (30\%), owing to the low solubility of 23 in THF. DIBAl-H reduction of ester 24 gave allylic alcohol $25(90 \%)$, which smoothly underwent Charette cyclopropanation to produce the cyclopropyl alcohol 27 (87\%). Oxidation of alcohol 27 by Dess-Martin periodinane gave the corresponding aldehyde $\mathbf{2 8}$ (Scheme 6). These results clearly indicated that the failure in our attempted tetracyclopropanation of tetra-cis-alkene $\mathbf{2 1}$ under Charette conditions was only the result of low solubility.

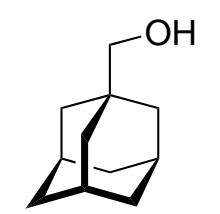

22

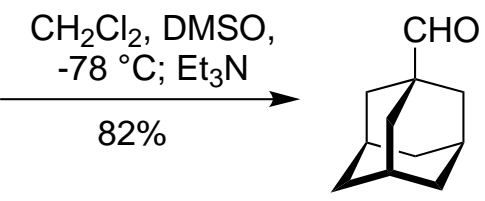

23
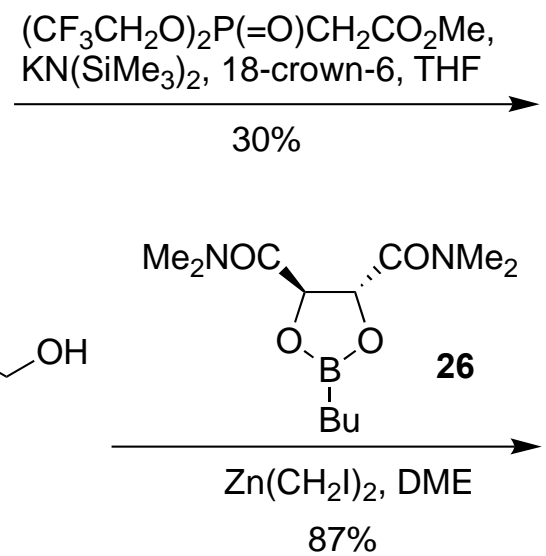

24

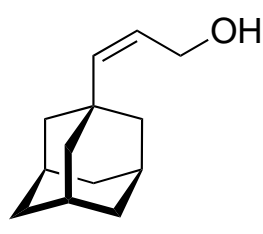

25

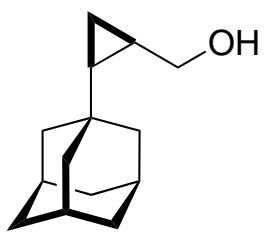

27

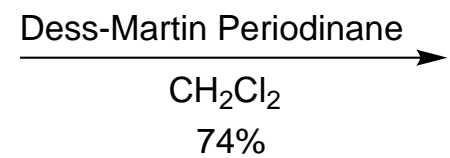

$74 \%$

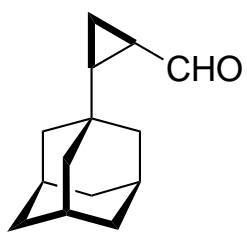

28

Scheme 6. Synthesis of cyclopropane 28 using (Z)-selective Horner-Emmons and Charette Cyclopropanation.

In order to overcome the reactivity issues with the four-directional approach, desymmetrization and a three-directional strategy was examined. Mono-protection of tetraol $\mathbf{2 1}$ with $t$-butyldiphenylsilyl chloride in pyridine at room temperature gave the mono-silyl derivative 29 (44\%, 66\% allowing for 33\% recovered starting material). To our delight, triol 29 was soluble in dichloromethane and smoothly underwent triple Charette $^{35}$ cyclopropanation to produce tricyclopropane $30(90 \%)$ and this was desilylated using tetra- $n$ butylammonium fluoride in THF to give the tetraol 31 (94\%) (Scheme 7). Unfortunately, this tetraol 31 being insoluble in dichloromethane was inert to the Charette reagent. 


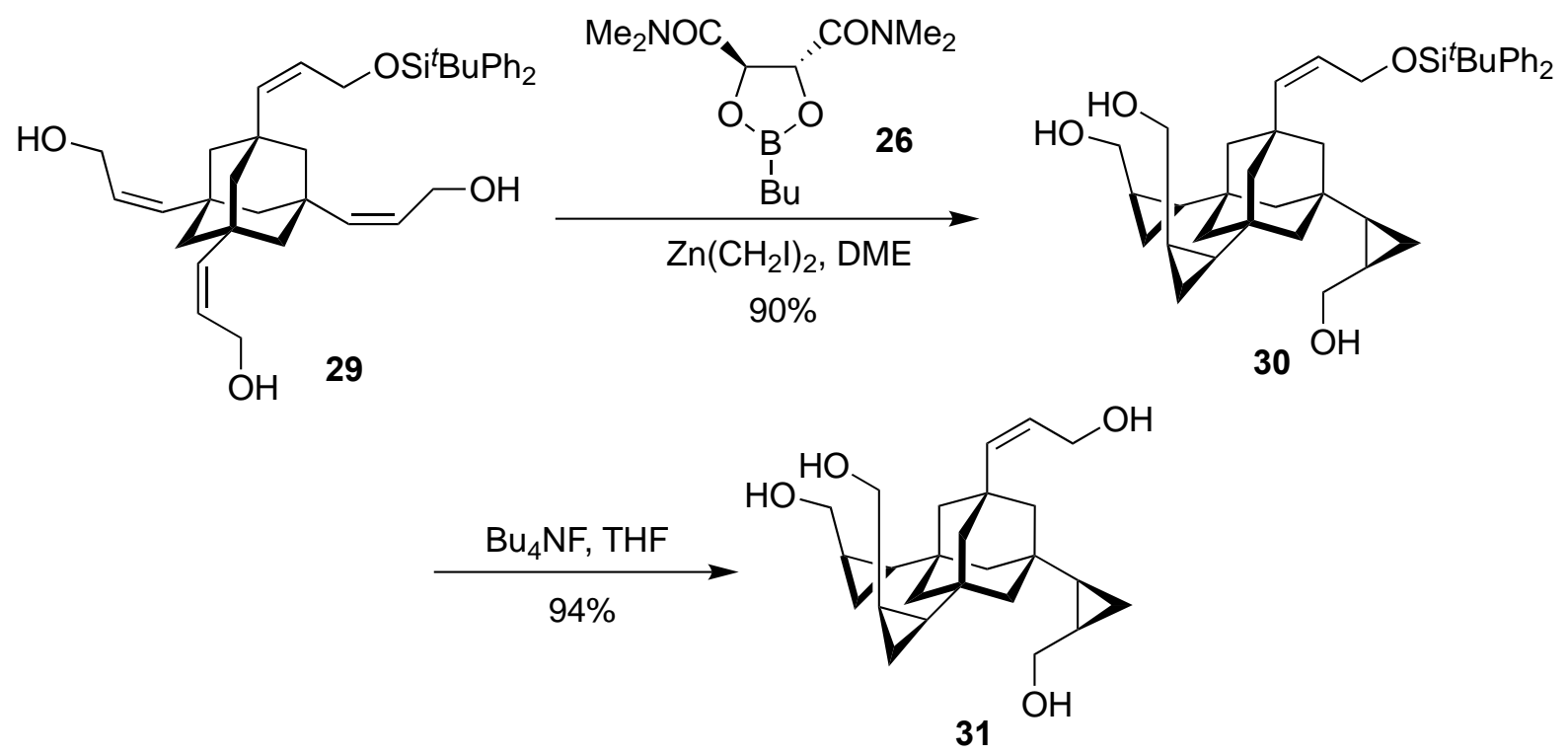

Scheme 7. Synthesis and three directional Charette enantioselective cyclopropanation of triol 29.

This solubility problem associated with tetraol $\mathbf{3 1}$ was circumvented by triple pivaloylation. Thus, acylation of triol $\mathbf{3 0}$ with pivaloyl chloride in pyridine gave the triester $\mathbf{3 2}$ (95\%), which was desilylated to give the allylic alcohol $\mathbf{3 3}$ (95\%). Charette cyclopropanation of the dichloromethane soluble allylic alcohol $\mathbf{3 3}$ gave the tetra-cyclopropane 34 (63\%). Finally, the key intermediate tetra-syn-cyclopropyl alcohol 35 (90\%) was obtained by DIBAI-H reductive deacylation of the tri-pivaloate 34 (Scheme 8). The constitution of the tetrasyn-cyclopropyl alcohol $\mathbf{3 5}$ was confirmed by a single crystal X-ray structure determination (see Supplementary Material: Appendix-2). We were unable to define the absolute stereochemistry due to the lack of heavy atoms in the molecule. Perhaps unsurprisingly, the structure is disordered and actually shows an inversion of chirality in one of the four cyclopropyl arms. The figures in Appendix-2 show both diastereoisomers individually and overlapped, with the major diastereoisomer 35A being ca. 64\% occupancy, and the minor diastereoisomer 35B ca. 36\% occupancy and with each diastereoisomer possessing greater than 95\% optical purity. Presumably, the final cyclopropanation reaction showed significantly lower diastereoselectivity than expected with the Charette chiral boronate $\mathbf{2 6}$ additive and/or recrystallization enhanced the percentage of the minor diastereoisomer. The ${ }^{13} \mathrm{C}$ NMR spectrum of the tetraol 35 did not show any duplication of any peaks. 


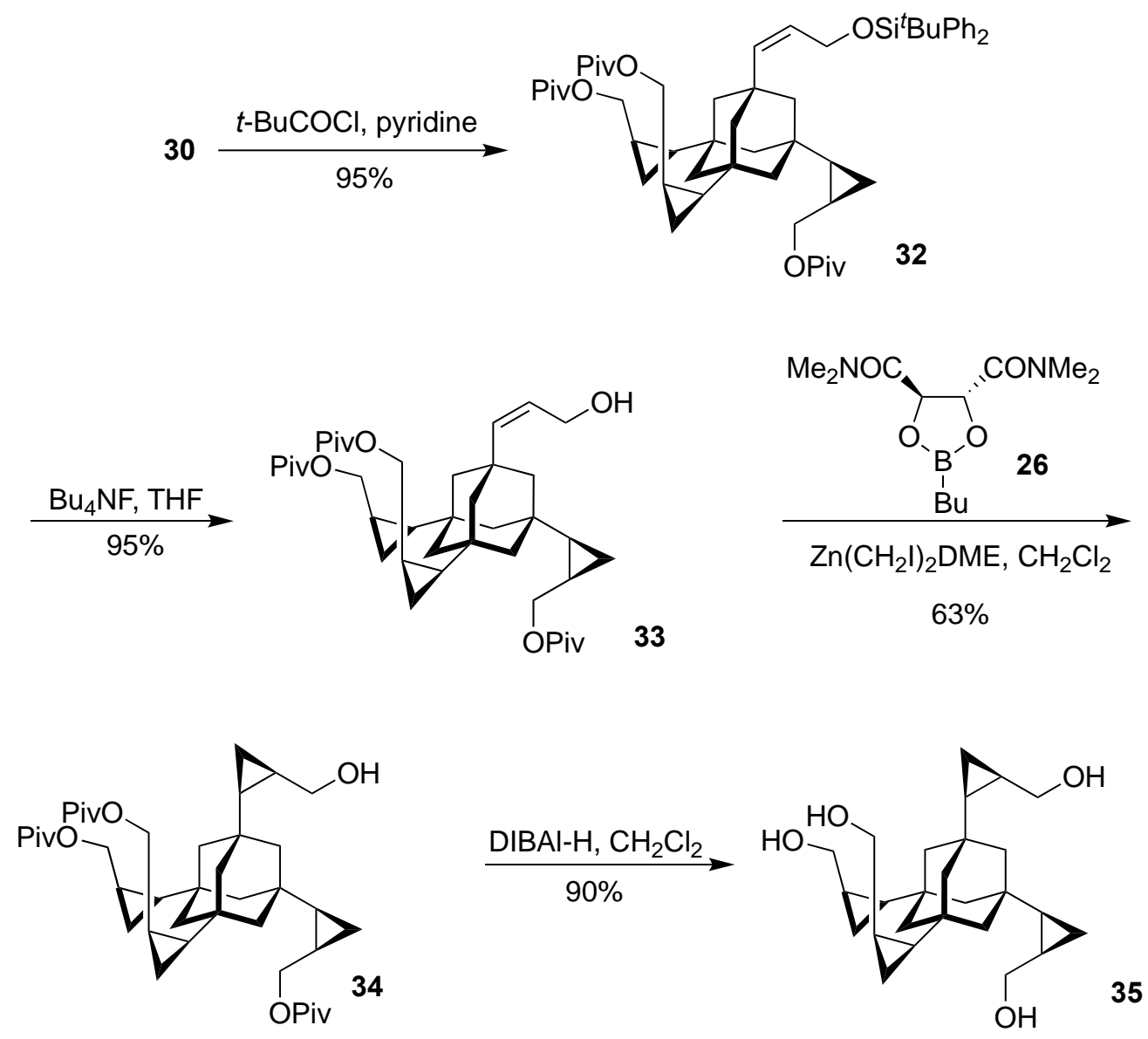

Scheme 8. Completion of the synthesis of target tetra-syn-cyclopropyl alcohol $\mathbf{3 5 .}$

Swern oxidation of tetraol $\mathbf{3 5}$ was carried out in DMSO and dichloromethane solution due to poor solubility in dichloromethane alone. This gave the tetra-aldehyde $\mathbf{1 4}$ and subsequent condensation with $p$ toluenesulfonylhydrazine gave the derived tetra-tosylhydrazone 36 (82\%) (Scheme 9). Attempts to generate tetra-carbene $\mathrm{C}-\mathrm{H}$ insertion or fragmentation products from the tetra-tosylhydrazone $\mathbf{3 6}$ by conversion to the derived tetra-potassium salt, generated with either potassium tert-butoxide or potassium hexamethyldisilazide, and aprotic Bamford Stevens thermolysis at $138{ }^{\circ} \mathrm{C}$ or reaction with dirhodium tetraacetate in the presence of the phase transfer catalysts benzyltriethylammonium chloride or 18 -crown- $6^{36}$ in dioxane or dichloromethane gave only intractable materials. Evidence for the formation of potassium salt from tetra-tosylhydrazone $\mathbf{3 6}$ was seen in the IR spectum with shifts of the sulfone stretches from 1332 and $1162 \mathrm{~cm}^{-1}$ to 1228 and $1126 \mathrm{~cm}^{-1}$ on reaction with the two bases.

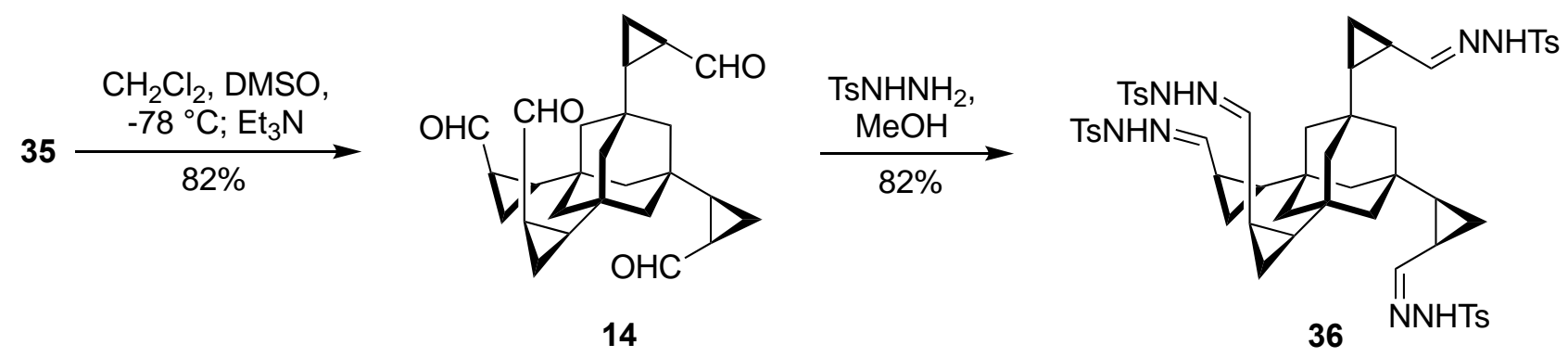

Scheme 9. Synthesis of tetra-4-toluenesulfonylhydrazone $\mathbf{3 6 .}$ 


\section{Four-directional homologation of 1,3,5,7-adamantanetetraacetic acid derivatives}

In the light of the difficulties with the four-directional reactions to synthesize the adamantane derivatives $\mathbf{3 5}$ and $\mathbf{1 4}$, studies on four-directional rhodium catalyzed $\mathrm{C}-\mathrm{H}$ insertion reactions of adamantanes functionalized with four tertiary $\alpha$-diazo- $\beta$-keto-ester units were carried out. Three model adamantane systems with one $\alpha$ diazo- $\beta$-keto-ester unit and two $\alpha$-diazo- $\beta$-keto-ester units were also synthesized. The known aldehyde $\mathbf{3 8}$ was synthesized from the commercially available alcohol $\mathbf{3 7}$ by Swern oxidation. ${ }^{37}$ Interestingly, upon standing overnight at room temperature, the aldehyde $\mathbf{3 8}$ underwent hydration to give the corresponding geminal diol very easily. Therefore aldehyde $\mathbf{3 8}$ was used in the next step immediately following its purification. Treatment of freshly prepared aldehyde $\mathbf{3 8}$ with ethyl diazoacetate in the presence of a catalytic amount of tin(II) chloride ${ }^{38}$ smoothly gave $\beta$-keto-ester 39 a as a 4:1 mixture of enol and keto tautomers. Finally, diazo transfer reaction of $\beta$-keto ester 39a with 4 -acetamidobenzenesulfonyl azide $(40)^{39}$ gave the $\alpha$-diazo- $\beta$-keto-ester 41 a (99\%). The aldehyde 38 was converted by the same method via $\beta$-keto-ester 39b (61\%) into the $\alpha$-diazo- $\beta$ keto-ester 41b (90\%) (Scheme 10).

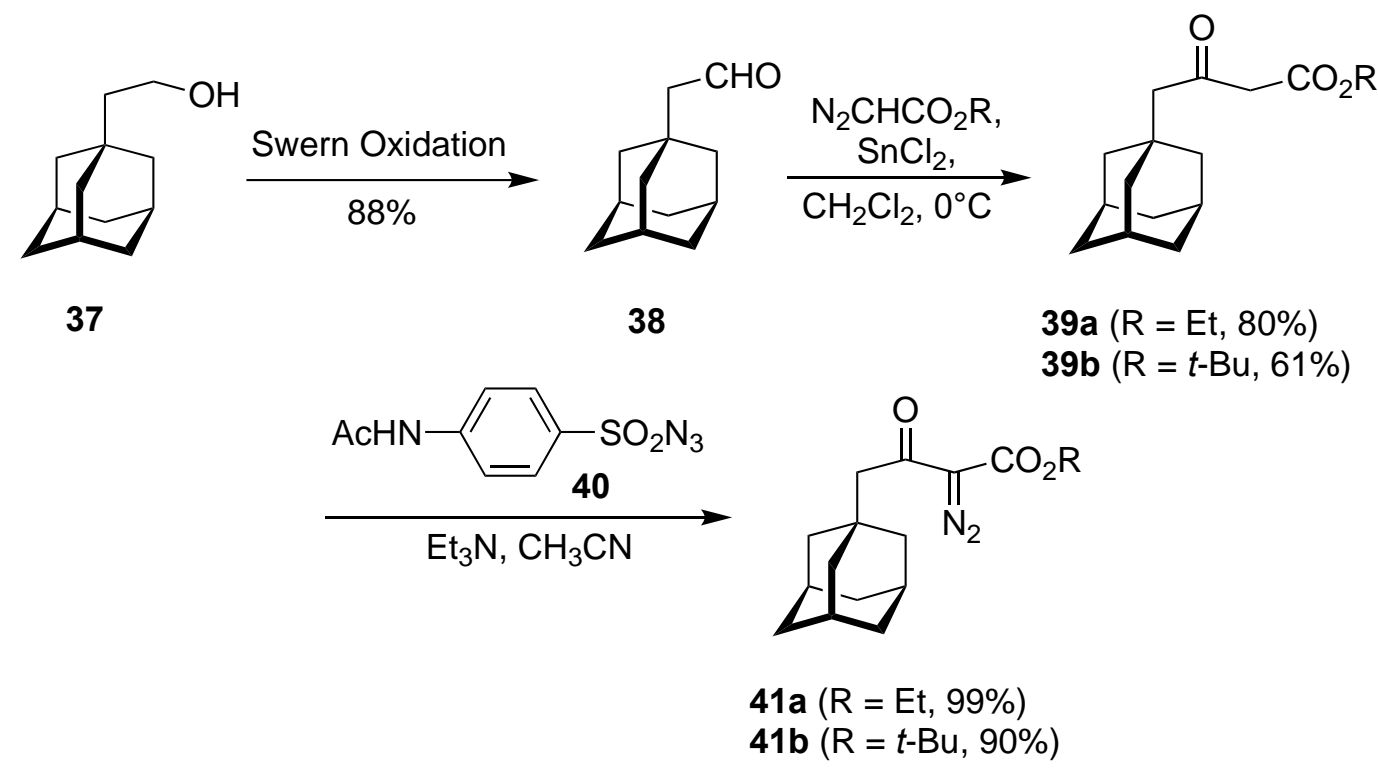

Scheme 10. Syntheses of $\alpha$-diazo- $\beta$-keto-esters 41.

The commercially available di-carboxylic acid $\mathbf{4 2}$ was reduced to the corresponding diol $\mathbf{4 3} 40$ (74\%) using lithium aluminum hydride. Swern oxidation of diol $\mathbf{4 3}$ gave dialdehyde $\mathbf{4 4}$, which was allowed to react with tert-butyl diazoacetate in the presence of tin(II) chloride to give the di- $\beta$-keto ester 45 (75\%). The diazo transfer reaction ${ }^{39}$ was used again to convert di- $\beta$-keto ester 45 to the desired di- $\alpha$-diazo- $\beta$-keto-ester 46 (Scheme 11). 


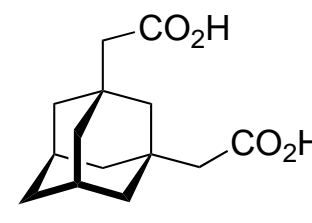

42

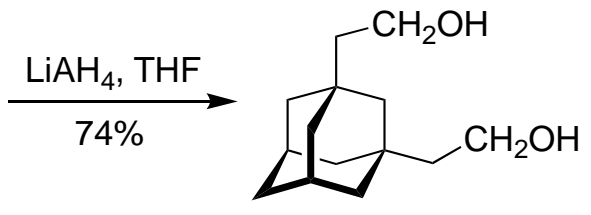

43

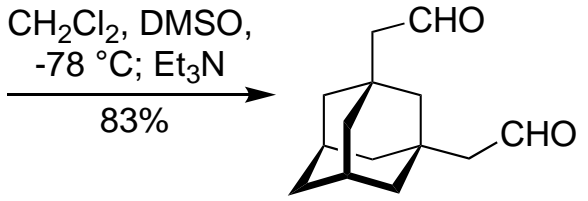

44

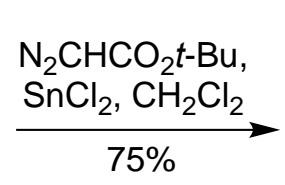

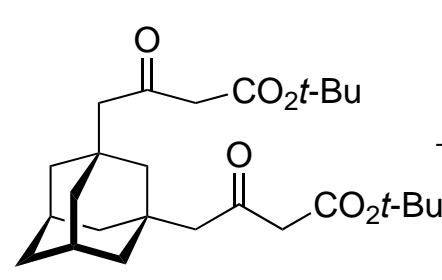

45

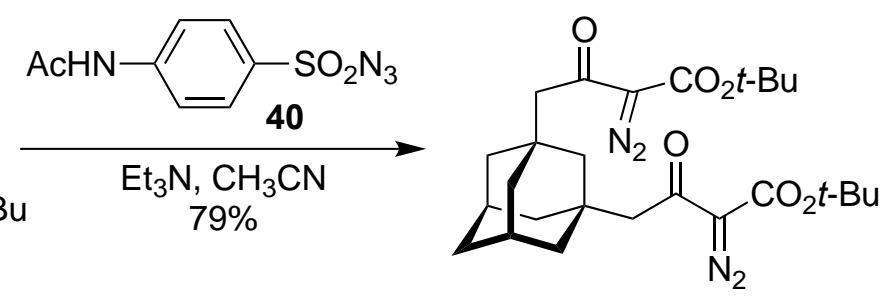

46

Scheme 11. Synthesis of di- $\alpha$-diazo- $\beta$-keto-ester 46.

Dirhodium tetraacetate catalyzed carbene insertion of $\alpha$-diazo- $\beta$-keto-esters $41 \mathbf{a}$ and $\mathbf{4 1}$ broceeded smoothly at room temperature to generate the cyclized products 47 a (90\%) and $47 \mathrm{~b}$ (91\%) both as single undetermined racemic stereoisomers. Respective Krapcho deethoxycarbonylation ${ }^{41}$ and TFA catalyzed $t$-butyl ester cleavage and decarboxylation in chlorobenzene at $120^{\circ} \mathrm{C}$ gave the same fused cyclopentanone $49^{42}(90$ and $99 \%$ respectively). Alternatively, TFA catalyzed $t$-butyl ester cleavage in dichloromethane at room temperature gave the $\beta$-keto-carboxylic acid 48 (99\%) and this smoothly gave the fused cyclopentanone 49 (82\%) on reflux in 1,4-dioxane (Scheme 12).
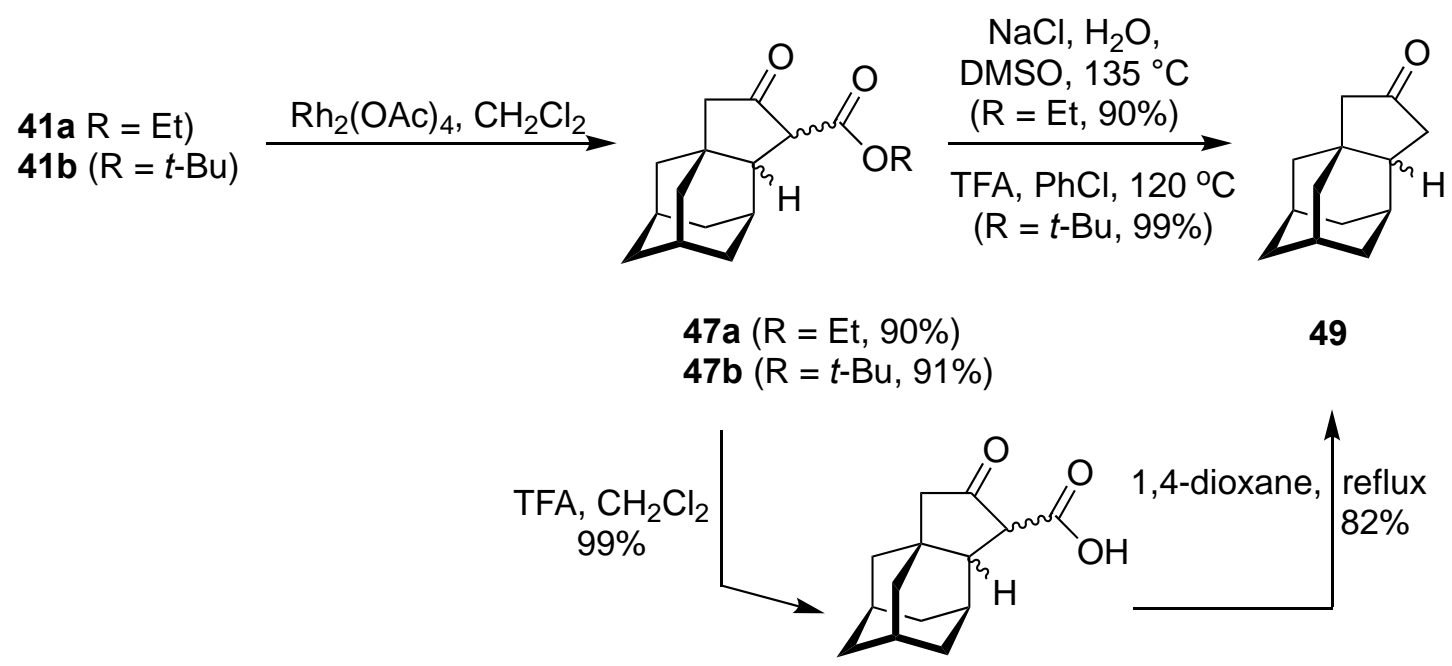

48

Scheme 12. Rhodium catalyzed $\mathrm{C}-\mathrm{H}$ insertion reactions of $\alpha$-diazo- $\beta$-keto-esters $\mathbf{4 1}$ and synthesis of ketone 49.

Double dirhodium tetraacetate catalyzed carbene insertion of di- $\alpha$-diazo- $\beta$-keto-ester 46 gave the doubly cyclized product 50 (52\%) along with minor unidentified by-products. Subsequent de-t-butylation and decarboxylation catalyzed by TFA in chlorobenzene at $115{ }^{\circ} \mathrm{C}$ proceeded smoothly and gave the di-cyclopentanone 51 (97\%) as an unidentified racemic stereoisomer (Scheme 13). It should be noted that 
there are many possible stereo- and regio-isomers arising from the double carbene insertion reaction of di- $\alpha$ diazo- $\beta$-keto-ester 46. For example, the final diketone $\mathbf{5 1}$ could either have the syn-51 and/or the anti-51 constitution and each of these could have the meso- and/or ( \pm )-stereochemistry (Figure 1).

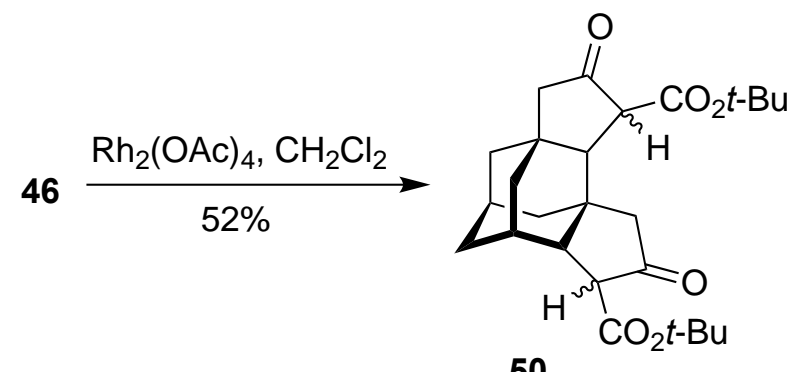

50

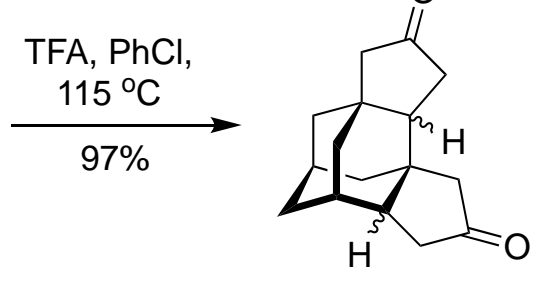

51

Scheme 13. Rhodium catalyzed $\mathrm{C}-\mathrm{H}$ insertion reactions of $\alpha$-diazo- $\beta$-keto-ester $\mathbf{4 6}$ and synthesis of dione $\mathbf{5 1 .}$

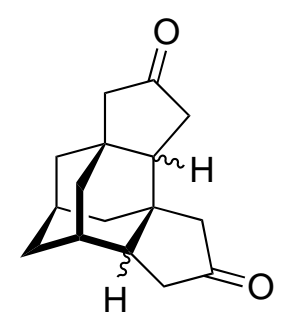

syn-51

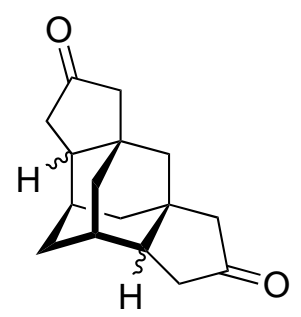

anti-51

Figure 1. Possible isomers of ketone $\mathbf{5 1 .}$

Wittig reaction ${ }^{17}$ of tetra-aldehyde 19 with excess of methoxymethyl-triphenylphosphonium chloride and sodium hexamethyldisilazane gave tetra-enol ether $\mathbf{5 2}(\mathbf{7 9 \% )}$ as a mixture of $(E)$ - and (Z)-olefins. Hydrolysis using triflic acid in aqueous dichloromethane and iso-propanol gave the tetra-aldehyde 53 (60\%). The yield of tetra-aldehyde $\mathbf{5 3}$ was inferior if the intermediate enol ether $\mathbf{5 2}$ was not isolated due to greater difficulty in purification. Pinnick oxidation ${ }^{43}$ of tetra-aldehyde 53 smoothly gave the desired tetra-acid 54a (83\%), which was converted via the tetra-acyl chloride (IR $1802 \mathrm{~cm}^{-1}$ ) into the tetramethyl ester 54b (42\%). Attempts to convert the tetra-acid 54a via its derived tetra-acyl chloride or via its tetra-mixed anhydride with ethyl chloroformate to the derived tetra-diazo-ketone by reaction with diazomethane gave only intractable mixtures of products. In contrast tetra-aldehyde $\mathbf{5 3}$ was smoothly converted into the tetra- $\beta$-keto-ester $\mathbf{1 5 a}$ $(82 \%)$, which was obtained as a mixture of enol and keto-tautomers (ca $3: 1$ ), by reaction with ethyl diazoacetate in the presence of $\operatorname{tin}(\mathrm{II})$ chloride ${ }^{38}$ and subsequently into the tetra- $\alpha$-diazo- $\beta$-keto-ester 55 a (97\%) by diazo transfer from 4-acetamidobenzenesulfonyl azide (40). ${ }^{39}$ In the same way, the tetra-aldehyde $\mathbf{5 3}$ was readily converted into the tetra- $\beta$-keto-ester $\mathbf{1 5 b}(81 \%)$, which was obtained as a mixture of enol and keto-tautomers (ca $4: 1$ ), and thence into the tetra- $\alpha$-diazo- $\beta$-keto-ester 55b (99\%) (Scheme 14). 

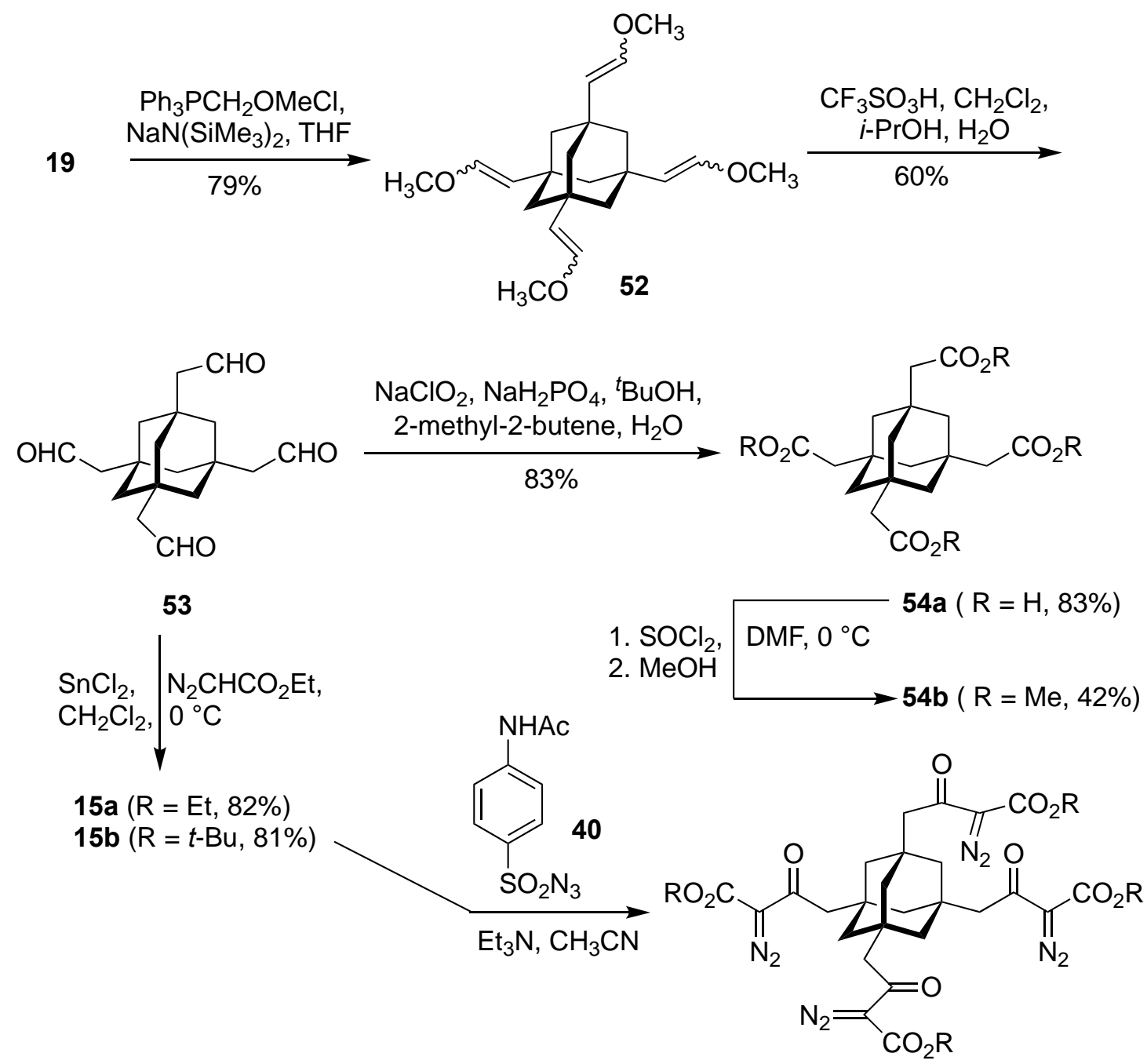

55a $(R=E t, 97 \%)$

$55 \mathrm{~b}(\mathrm{R}=t-\mathrm{Bu}, 99 \%)$

Scheme 14. Conversion of tetra-aldehyde 19 via tetra-aldehyde $\mathbf{5 3}$ into tetra- $\alpha$-diazo- $\beta$-keto-esters $\mathbf{5 5 a}$ and 55b.

A range of catalysts were examined for the attempted quadruple $\mathrm{C}-\mathrm{H}$ insertion reaction of tetra- $\alpha$ diazo- $\beta$-keto-ester 55a. Reactions using dirhodium tetraacetate in dilute solution $(0.01 \mathrm{M})$ in dichloromethane at room temperature, copper sulfate or copper iodide in toluene at room temperature or reflux all were unsuccessful. In contrast, catalysis using dirhodium tetra-carboxylate (acetate, trifluoroacetate, perfluorobutyrate, octanoate) salts at reflux in toluene or trifluoromethylbenzene gave an isolable fraction by chromatography that may have contained carbene insertion products. For example, catalysis with dirhodium tetra-octanoate in toluene at reflux with slow addition of the tetra- $\alpha$-diazo- $\beta$-keto-ester 55 a gave a complex product mixture that may have contained the tetra- $\beta$-keto-ester $56 \mathrm{a}$. The ${ }^{1} \mathrm{H}$ and ${ }^{13} \mathrm{C}$ NMR spectra of the product was complex presumably due to the presence of multiple isomers and the molecular ion could not be detected in the mass spectrum, although the IR spectrum was consistent with the presence of ester and ketocarbonyl groups (keto-ester 47a at 1755 and $1724 \mathrm{~cm}^{-1}$ and tetra- $\beta$-keto-ester 56a at 1753 and $1725 \mathrm{~cm}^{-1}$ ). Attempted Krapcho deethoxycarbonylation ${ }^{41}$ of the product mixture failed to produce identifiable products. 
Reaction of the tetra- $\alpha$-diazo- $\beta$-keto-ester $\mathbf{5 5 b}$ with dirhodium tetra-octanoate in toluene $(0.01 \mathrm{M})$ at reflux with slow addition of the substrate gave a complex product mixture that may have contained the tetra$\beta$-keto-ester 56b. Again, this structural assignment was tentative since the ${ }^{1} \mathrm{H}$ and ${ }^{13} \mathrm{C}$ NMR spectra of the product was complex presumably due to the presence of multiple isomers and the molecular ion could not be detected in the mass spectrum, although the IR spectrum was consistent with the presence of an ester and keto-carbonyl groups (1747 and $\left.1722 \mathrm{~cm}^{-1}\right)$ (Scheme 15). Attempted global de-t-butylation and decarboxylation catalyzed by TFA using the one step or two step methods in Scheme 12, failed to provide any isolable material although the $t$-butyl esters were cleaved.

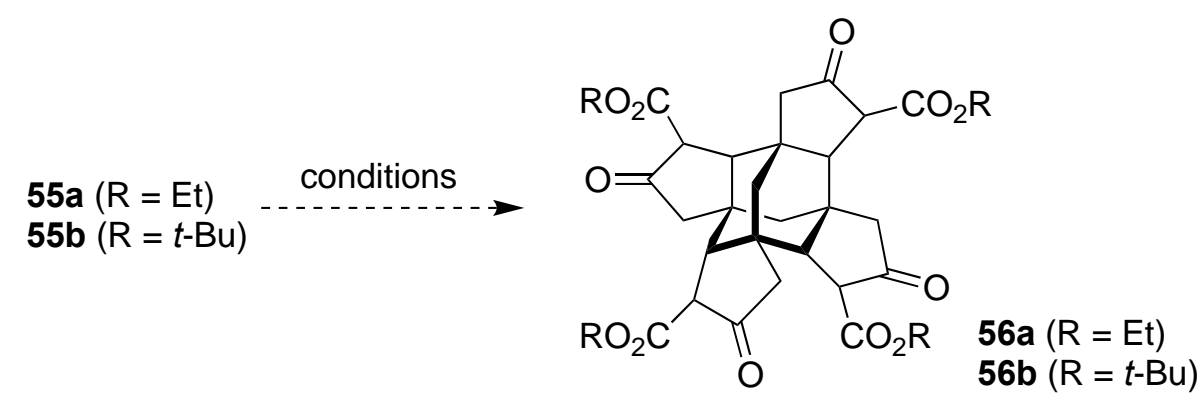

Scheme 15. Attempted syntheses of tetra- $\beta$-keto-esters 56.

\section{Synthesis of and Dimerization of Adamantanocyclopentadiene 59}

Ketone 49 was synthesized by the methods in Scheme 12 and additionally by sequential reaction of 1adamantaneacetic acid with thionyl chloride, diazomethane in diethyl ether and copper sulfate in toluene at reflux. ${ }^{42}$ Conversion to the cyclopentenone $\mathbf{5 7}$ was carried out in modest yield (23\% with $32 \%$ recovery of starting material) by enol silane formation with lithium 2,2,6,6-tetramethylpiperidide (LiTMP), trimethylsilyl chloride and triethylamine and Saegusa oxidation with palladium acetate. DIBAI-H reduction of the cyclopentenone 57 at $-78{ }^{\circ} \mathrm{C}$ gave the allylic alcohol 58 (90\%) and this delicate compound underwent complete dehydration, presumably $\mathrm{DCl}$ catalyzed, in deuterated chloroform over 2 hours during the recording of NMR spectra to produce diene $\mathbf{5 9}$ (82\% isolated yield) (Scheme 16).
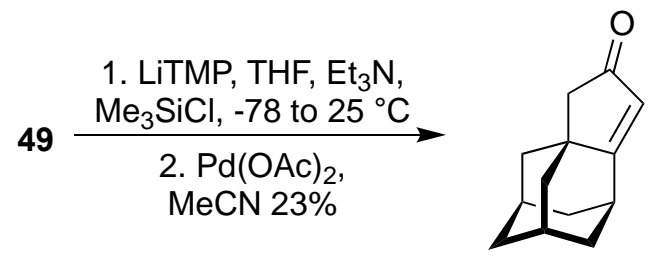

57

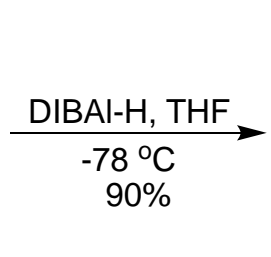

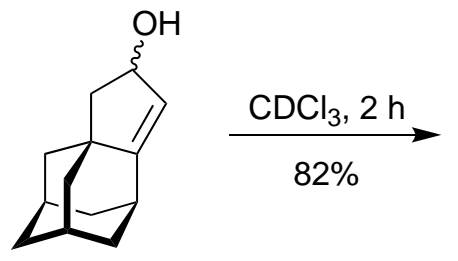

58

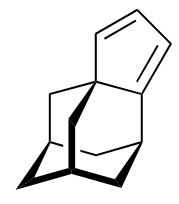

59

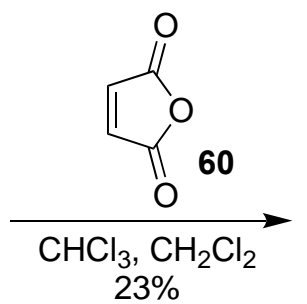

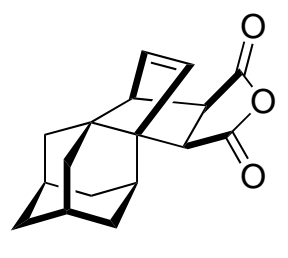

61

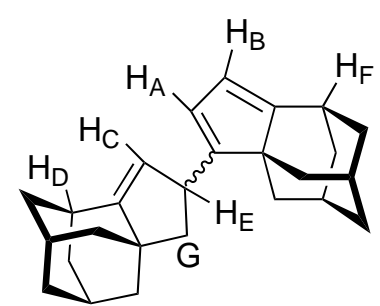

63

Scheme 16. Synthesis and reactions of cyclopentadiene derivative 59. 
Diene 59 underwent a Diels-Alder reaction with maleic anhydride (60) to produce the adduct 61 (23\% unoptimized). Whilst diene $\mathbf{5 9}$ did not undergo dimerization by a self-Diels-Alder reaction on standing for 23 days, it did undergo an alternative dimerization reaction in the presence of tris( $p$-bromophenyl)aminium hexachloroantimonate (62), a known SET acceptor for mediating Diels-Alder reactions via diene cation radicals. ${ }^{44}$ Of particular interest in this context is the known Diels-Alder rapid dimerization of 1 ,3cyclohexadiene mediated by an SET pathway with aminium cation radical modulators, although 1,3cyclohexadiene in known not to be normally reactive towards such self-Diels-Alder reactions below $200{ }^{\circ} \mathrm{C}$. Attempted SET-Diels-Alder reaction of diene 59 gave an adduct that was assigned as dimer $\mathbf{6 3}$ (40\%). Clearly a product this unexpected requires some further discussion with regard to its assignment.

The proposed structure 63 was elucidated based on the following key facts and explanations: (1) the dimer 63 has the molecular formula of $\mathrm{C}_{26} \mathrm{H}_{32}$ as confirmed by MS and high resolution MS; (2) there are three vinyl protons $(\delta 6.30,5.93,5.21 \mathrm{ppm})$ in the ${ }^{1} \mathrm{H}$ NMR spectrum; $(3)$ there are three quaternary olefinic carbons $(\delta 162.2,157.9$ and $153.0 \mathrm{ppm})$ and three tertiary olefinic carbons $(\delta 123.9,117.4,114.6 \mathrm{ppm})$ in ${ }^{13} \mathrm{C} N \mathrm{NM}$ and ${ }^{13} \mathrm{C}$ DEPT spectra (see Supplementary Material: Appendix-3); (4) there are two adjacent vinyl protons ( $\delta 6.30$ and $5.93 \mathrm{ppm}$ ), which are correlated to each other have the coupling constant of $1.9 \mathrm{~Hz}$ in the ${ }^{1} \mathrm{H}$ NMR and ${ }^{1} \mathrm{H}$ COSY spectra and this coupling constant is consistent with bonding B and not bonding A below (Figure 2); (5) there are three relatively low-field proton signals $(\delta 3.74 \mathrm{ppm}, 2.98 \mathrm{ppm}$ and $2.75 \mathrm{ppm})$ and these protons must be positioned next to a carbon-carbon double bond $\left(H_{D}, H_{E}\right.$ and $H_{F}$ in the structure 63 in Scheme 16); (6) there is one proton ( $\delta 3.72 \mathrm{ppm}$ ) next to a carbon-carbon double bond has the correlation with one vinyl proton and two protons in a $\mathrm{CH}_{2}$ unit from the ${ }^{1} \mathrm{H}$ COSY and ${ }^{1} \mathrm{H} /{ }^{13} \mathrm{C}$ correlation spectra (see Appendix-3) $\left(\mathrm{H}_{\mathrm{E}}\right.$ in the structure 63 in Scheme 16); (7) the $\lambda_{\max }$ in the UV spectrum is at $262 \mathrm{~nm}(\log \varepsilon) 262$ (3.76) is inconsistent with the alkene and cyclopentadiene units being in conjugation since 1,4,5,5-tetramethylcyclopentadiene shows a $\lambda_{\max }$ of $258 \mathrm{~nm}^{45}$ and if the third double bond was conjugated with the cyclopentadiene unit, the absorption maximum should be significantly red shifted. In spite of these considerations, the structural assignment for the dimer 63 must, in the absence of an X-ray crystallographic structure determination, be considered tentative.

big coupling costant

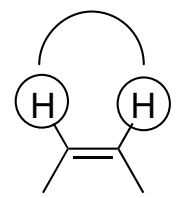

Bonding A small coupling constant

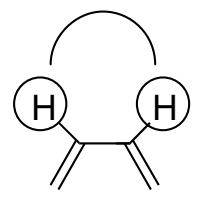

Bonding B

Figure 2. Vinyl coupling constants in the ${ }^{1} \mathrm{H}$ NMR relevant to the constitution of dimer 63.

\section{Conclusions}

It is clear that not all transformations are readily amenable to four-directional synthesis of adamantane derivatives either for issues of low solubilities and/or the formation of multiple products. Nonetheless, (Z)selective Horner-Emmons reaction of tetra-aldehyde 19 under Still-Gennari conditions, DIBAI-H reduction of 
tetra-ester 20, Wittig reaction of tetra-aldehyde 19 with methoxymethylenetriphenylphosphorane and subsequent Pinnick oxidation of the derived tetra-aldehyde 53, Roskamp coupling of condensation of tetraaldehyde 53 with both ethyl and $t$-butyl diazoacetate and conversions of the derived $\beta$-keto-esters 15a and 15b with 4-acetamidobenzenesulfonyl azide (40) to produce the $\alpha$-diazo- $\beta$-keto-esters 55a and 55b all worked well in a four-directional sense. Although, three-directional Charette enantioselective cyclopropanation of triol $\mathbf{2 9}$ was successful, the equivalent four-directional reaction on tetraol $\mathbf{2 1}$ failed due to low solubility. Whilst one-directional rhodium catalyzed $\mathrm{C}-\mathrm{H}$ insertion of the carbene derived from $\alpha$-diazo- $\beta$-keto-esters $41 \mathrm{a}$ and 41b and two-directional rhodium catalyzed $\mathrm{C}-\mathrm{H}$ insertion of the carbenes derived from the di- $\alpha$-diazo- $\beta$-ketoester 46 all gave adamantane-cyclopentanone annulation products $47 \mathrm{a}, \mathbf{4 7} \mathrm{b}$ and 50 and thence 48, 49, 50 and 51, related four-directional carbene reactions gave only intractable mixtures. The adamantane cyclopentadiene 59 underwent dimerization to the adduct 63 and not to the Diels-Alder product.

\section{Experimental Section}

General. Melting points were obtained on a hot stage melting point apparatus and are uncorrected. Infrared spectra were recorded as thin films on sodium chloride plates with absorptions reported in wavenumbers ( $\mathrm{cm}^{-}$ $\left.{ }^{1}\right)$. ${ }^{1} \mathrm{H}$ NMR spectra were recorded at $300 \mathrm{MHz}, 400 \mathrm{MHz}$ and $500 \mathrm{MHz}$ with chemical shifts $(\delta)$ quoted in parts per million (ppm) and referenced to the residual solvent peak, 7.27 for $\mathrm{CDCl}_{3}, 7.15$ for $\mathrm{C}_{6} \mathrm{D}_{6}, 3.34$ for methanol$d_{4}, 2.52$ for DMSO- $d_{6} .{ }^{13} \mathrm{C}$ NMR spectra were recorded at $75 \mathrm{MHz}, 100 \mathrm{MHz}$ and $125 \mathrm{MHz}$ with chemical shifts

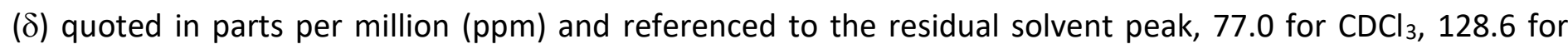
$\mathrm{C}_{6} \mathrm{D}_{6}, 49.9$ for methanol- $d_{4}, 39.7$ for DMSO- $d_{6}$. Coupling constants $(J)$ are quoted in $\mathrm{Hertz}(\mathrm{Hz})$ for both ${ }^{1} \mathrm{H}$ and ${ }^{13}$ C NMR spectra.

All reactions were carried out in oven or flame-dried glassware under an inert atmosphere of nitrogen or argon. Reaction temperatures other than room temperature were recorded as bath temperatures unless otherwise stated. $\mathrm{CH}_{2} \mathrm{Cl}_{2}, \mathrm{MeOH}$, pyridine and $\mathrm{Et}_{3} \mathrm{~N}$ were distilled from calcium hydride under a nitrogen atmosphere. $\mathrm{Et}_{2} \mathrm{O}$ and THF were distilled from sodium benzophenone ketyl under a nitrogen atmosphere. PhMe was distilled from sodium under a nitrogen atmosphere. Column chromatography was performed on silica gel 60 , particle size $20-63 \mu \mathrm{m}$ or particle size $33-70 \mu \mathrm{m}$. TLC was performed on silica gel $60 \mathrm{~F}_{254}$ glassbacked plates with visualization under ultraviolet light $254 \mathrm{~nm}$ and/or by chemical staining using a potassium permanganate dip and drying with a heat gun.

Tetramethyl 1,3,5,7-Adamantanetetracarboxylate (18). 1,3-Adamantanedicarboxylic acid 16 (10.0 g, 44.6 $\mathrm{mmol})$ and freshly distilled thionyl chloride $(60 \mathrm{~mL})$ were heated at reflux with vigorous stirring for $2 \mathrm{~h}$ and the excess thionyl chloride was removed in vacuo. The mixture was cooled to room temperature and dry $\mathrm{PhH}(50$ $\mathrm{mL}$ ) was added which was further removed in vacuo to give an off-white solid, which was stored under vacuum for $12 \mathrm{~h}$ to leave crude 1,3-adamantanedicarbonyl chloride 17 (11.7 g) as an off-white solid. This material showed spectroscopic data consistent with the reported values. ${ }^{31}$ 1,3-Adamantanedicarbonyl chloride 17 (11.7 g, $44.6 \mathrm{mmol})$ in oxalyl chloride $(130 \mathrm{~mL})$ was irradiated at $20{ }^{\circ} \mathrm{C}$ by a medium pressure mercury-vapor lamp (450 Watts) immersed into a double-walled quartz well with inlet and outlet tubes for cooling. The reaction vessel constructed of glass was placed outside the immersion well with one vertical joint for the condenser. After $16 \mathrm{~h}$ of irradiation, the excess oxalyl chloride was removed on a rotary evaporator and the residue was stirred with dry $\mathrm{MeOH}(80 \mathrm{~mL})$ at room temperature overnight. The mixture was concentrated in vacuo, the oily residue was dissolved in EtOAc $(100 \mathrm{~mL})$, washed with $5 \%$ aqueous $\mathrm{Na}_{2} \mathrm{CO}_{3}(30$ 
$\mathrm{mL})$ and brine $(30 \mathrm{~mL})$ and the organic layer was dried $\left(\mathrm{MgSO}_{4}\right)$, and concentrated in vacuo. The residue was triturated with the minimal amount of $\mathrm{MeOH}$ and the solid filtered off and dried under vacuum to give tetraester 18 (4.2 g; 25\%, over 2 steps) as colorless crystals: mp 167 - $168{ }^{\circ} \mathrm{C}$ (hexanes : EtOAc, 5 : 1) (lit. ${ }^{30} \mathrm{mp} 168$ $170{ }^{\circ} \mathrm{C}$ ); $R_{f} 0.36$ (hexanes : EtOAc, $2: 1$ ); IR (film) 1725, 1429, $1306 \mathrm{~cm}^{-1} ;{ }^{1} \mathrm{H} \mathrm{NMR}\left(300 \mathrm{MHz}, \mathrm{CDCl}_{3}\right) \delta 3.69$ (s, $\left.12 \mathrm{H}, \mathrm{OCH}_{3}\right), 1.99\left(\mathrm{~s}, 12 \mathrm{H}, \mathrm{CH}_{2}\right) ;{ }^{13} \mathrm{C} \mathrm{NMR}\left(75 \mathrm{MHz}_{\mathrm{CDCl}}\right) \delta 175.5,52.1,41.7,38.5 ; \mathrm{MS}(\mathrm{ES}) \mathrm{m} / z 369\left(\mathrm{M}+\mathrm{H}^{+}\right)$; HRMS (ES) $m / z$ calc for $\mathrm{C}_{18} \mathrm{H}_{25} \mathrm{O}_{8} 369.1549$, found: 369.1559 .

1,3,5,7-Tetrakis(hydroxymethyl)adamantane (13). ${ }^{18}$ Tetra-ester 18 (3.0 g, $8.15 \mathrm{mmol}$ ) in THF (40 mL) was added dropwise with stirring to a suspension of $\mathrm{LiAlH}_{4}(1.24 \mathrm{~g}, 32.6 \mathrm{mmol})$ in THF $(32 \mathrm{~mL})$ at $0{ }^{\circ} \mathrm{C}$ under argon. The mixture was heated at reflux for $3 \mathrm{~h}$, cooled and saturated aqueous $\mathrm{Na}_{2} \mathrm{SO}_{4}(2.43 \mathrm{~mL})$ was added carefully to with stirring to quench the reaction. After $30 \mathrm{~min}$, THF $(40 \mathrm{~mL}), \mathrm{MeOH}(40 \mathrm{~mL})$ and silica gel $(2.0 \mathrm{~g})$ were added, and the mixture was filtered through a short pad of Celite. Rotary evaporation and flash chromatography $\left(\mathrm{CH}_{2} \mathrm{Cl}_{2}: \mathrm{MeOH}, 10: 1\right.$ to 8:1) to give tetraol 13 (1.90 g, 91\%) as a white solid: $\mathrm{mp} 226-228^{\circ} \mathrm{C}$ (MeOH) (lit. $\left.{ }^{18} \mathrm{mp} 231-232{ }^{\circ} \mathrm{C}\right) ; R_{f} 0.36\left(\mathrm{CH}_{2} \mathrm{Cl}_{2}: \mathrm{MeOH}, 4: 1\right)$; IR (film) 3323 broad, 2919, 2851, $1576 \mathrm{~cm}^{-1}$; ${ }^{1} \mathrm{H}$ NMR (300 MHz, MeOH-d $\left.d_{4}\right) \delta 3.26\left(\mathrm{~s}, 8 \mathrm{H}, \mathrm{CH}_{2} \mathrm{OH}\right), 1.21\left(\mathrm{~s}, 12 \mathrm{H}, \mathrm{CH}_{2}\right) ;{ }^{13} \mathrm{C} \mathrm{NMR}\left(75 \mathrm{MHz}, \mathrm{MeOH}-d_{4}\right) \delta 73.3$, 41.5, 37.2; MS (EI) $m / z 256\left(\mathrm{M}^{+}\right.$); HRMS (EI) $m / z$ calc for $\mathrm{C}_{14} \mathrm{H}_{24} \mathrm{O}_{4} 256.1675$, found: 256.1678.

1,3,5,7-Adamantanetetracarboxaldehyde (19). ${ }^{17}$ Anhydrous DMSO (4.66 mL, $65.7 \mathrm{mmol}$ ) in $\mathrm{CH}_{2} \mathrm{Cl}_{2}(12 \mathrm{~mL})$ was added over $10 \mathrm{~min}$ with vigorous stirring to oxalyl chloride $(2.82 \mathrm{~mL}, 32.9 \mathrm{mmol})$ in $\mathrm{CH}_{2} \mathrm{Cl}_{2}(18 \mathrm{~mL})$ at -78 ${ }^{\circ} \mathrm{C}$. After $15 \mathrm{~min}$, tetraol 13 (990 mg, $\left.3.87 \mathrm{mmol}\right)$ in anhydrous DMSO (15 mL) and $\mathrm{CH}_{2} \mathrm{Cl}_{2}(30 \mathrm{~mL})$ was added dropwise over $10 \mathrm{~min}$, and the reaction mixture was stirred at $-78{ }^{\circ} \mathrm{C}$ for $1 \mathrm{~h}$. $\mathrm{Et}_{3} \mathrm{~N}(22 \mathrm{~mL})$ was added dropwise with stirring, the mixture was allowed to warm up to room temperature, $\mathrm{H}_{2} \mathrm{O}(60 \mathrm{~mL})$ was added and the two phases were separated. The organic layer was washed with $5 \%$ aqueous $\mathrm{HCl}(20 \mathrm{~mL}), \mathrm{H}_{2} \mathrm{O}(20 \mathrm{~mL}), 5 \%$ aqueous $\mathrm{NaHCO}_{3}$ solution $(40 \mathrm{~mL})$ and brine $(20 \mathrm{~mL})$, dried $\left(\mathrm{MgSO}_{4}\right)$, concentrated in vacuo and the residue chromatographed (hexanes : EtOAc : MeOH, $1: 1: 0.02)$ to afford the tetra-aldehyde $19(670 \mathrm{mg}, 70 \%)$ as a white solid: $R_{f} 0.26$ (hexanes : EtOAc: $\mathrm{MeOH}, 1: 1: 0.2$ ); mp 142 - $144{ }^{\circ} \mathrm{C}$ (EtOAc) (lit. ${ }^{17} \mathrm{mp} 143-145{ }^{\circ} \mathrm{C}$ ); IR (film) 2935, 2856, 1719, $1449 \mathrm{~cm}^{-1} ;{ }^{1} \mathrm{H} \mathrm{NMR}\left(300 \mathrm{MHz}, \mathrm{CDCl}_{3}\right) \delta 9.51$ (s, 4H, CHO), $1.79\left(\mathrm{~s}, 12 \mathrm{H}, \mathrm{CH}_{2}\right) ;{ }^{13} \mathrm{C} \mathrm{NMR}$ $\left(75 \mathrm{MHz}, \mathrm{CDCl}_{3}\right) \delta 201.8,44.8,33.7$; MS (EI) $\mathrm{m} / \mathrm{z} 248\left(\mathrm{M}^{+}\right.$); HRMS (EI) $\mathrm{m} / z$ calc for $\mathrm{C}_{14} \mathrm{H}_{16} \mathrm{O}_{4}$ 248.1049, found: 248.1054.

Tetramethyl 3,3',3",3'"-(Adamantane-1,3,5,7-tetrayl)(2Z,2'Z,2'"Z,2'"Z)-tetraacrylate (20). KN(TMS)2 in PhMe (0.5 M; $4.26 \mathrm{~mL}, 2.13 \mathrm{mmol})$ was added dropwise with stirring to 18-crown-6 (2.80 g, $10.6 \mathrm{mmol})$ and bis(2,2,2-trifluoroethyl) (methoxycarbonylmethyl)phosphonate (762 mg, $2.40 \mathrm{mmol}$ ) in THF (3 mL) at $-78^{\circ} \mathrm{C}$. After $30 \mathrm{~min}$, tetra-aldehyde 19 (66 mg, $0.266 \mathrm{mmol})$ in THF (4 mL) was added and the mixture was allowed to warm up to $-20{ }^{\circ} \mathrm{C}$ over $2.5 \mathrm{~h}$, when reaction was quenched with saturated aqueous $\mathrm{NH}_{4} \mathrm{Cl}(5 \mathrm{~mL})$. The separated aqueous layer was extracted with EtOAc $(3 \times 8 \mathrm{~mL})$ and the combined organic layers were washed with brine, dried $\left(\mathrm{MgSO}_{4}\right)$, concentrated in vacuo and the residue chromatographed (hexanes : EtOAc, $\left.8: 1\right)$ to give the tetra-ester 20 (80 mg, 64\%) as a thick oil: $R_{f} 0.57$ (hexanes : EtOAc, 2 : 1); IR (film) 2951, 2920, 1726 $\mathrm{cm}^{-1} ;{ }^{1} \mathrm{H}$ NMR (300 MHz, CDCl 3$) \delta 5.85\left(\mathrm{~d}, J 13.1 \mathrm{~Hz}, 4 \mathrm{H}, \mathrm{CH}=\mathrm{CHCO}_{2} \mathrm{Me}\right), 5.70\left(\mathrm{~d}, J 13.1 \mathrm{~Hz}, 4 \mathrm{H}, \mathrm{CH}=\mathrm{CHCO}_{2} \mathrm{Me}\right)$, $3.72\left(\mathrm{~s}, 12 \mathrm{H}, \mathrm{OCH}_{3}\right), 1.97\left(\mathrm{~s}, 12 \mathrm{H}, \mathrm{CH}_{2}\right) ;{ }^{13} \mathrm{C} \mathrm{NMR}\left(75 \mathrm{MHz}, \mathrm{CDCl}_{3}\right) \delta 166.8,153.6,119.3,51.4,42.0,37.8$; MS (EI) $\mathrm{m} / \mathrm{z} 472\left(\mathrm{M}^{+}\right.$); HRMS (EI) $\mathrm{m} / z$ calc for $\mathrm{C}_{26} \mathrm{H}_{32} \mathrm{O}_{8} 472.2097$, found: 472.2101.

1,3,5,7-Tetra-(3-hydroxy-(1Z)-propenyl)adamantane (21). DIBAl-H in hexanes (1.0 M; $1.67 \mathrm{~mL}, 1.67 \mathrm{mmol}$ ) was added dropwise with stirring over 5 min to tetra-ester 20 (79 mg, $0.167 \mathrm{mmol}$ ) in $\mathrm{CH}_{2} \mathrm{Cl}_{2}(3 \mathrm{~mL})$ at $-78{ }^{\circ} \mathrm{C}$. 
After $1 \mathrm{~h}$, reaction was carefully quenched by the dropwise addition of saturated aqueous $\mathrm{NH}_{4} \mathrm{Cl}(0.30 \mathrm{~mL}), i$ $\mathrm{PrOH}(5 \mathrm{~mL})$, silica gel $(0.2 \mathrm{~g})$ and Celite $(0.2 \mathrm{~g})$. The mixture was allowed to warm to room temperature and filtered and the solids were washed with $\mathrm{CH}_{2} \mathrm{Cl}_{2} / i$-PrOH (2:1). Rotary evaporation of the combined filtrates and chromatography $\left(\mathrm{CH}_{2} \mathrm{Cl}_{2}: \mathrm{MeOH}, 16: 1\right.$ to $\left.12: 1\right)$ to give the tetra-allylic alcohol $21(78 \mathrm{mg}, 98 \%)$ as a solid. Colorless crystals of tetraol 21 were obtained by crystallization from MeOH/PhMe (1:1) at $4{ }^{\circ} \mathrm{C}: R_{f} 0.25\left(\mathrm{CH}_{2} \mathrm{Cl}_{2}\right.$ : MeOH, $8: 1$ ); mp $114-116{ }^{\circ} \mathrm{C}(\mathrm{MeOH}$ : toluene, $1: 1)$; IR (film) 3556, 2922, $2851 \mathrm{~cm}^{-1} ;{ }^{1} \mathrm{H} \mathrm{NMR}(300 \mathrm{MHz}$, $\left.\mathrm{MeOH}-d_{4}\right) \delta 5.41\left(\mathrm{dt}, J 12.4,6.2 \mathrm{~Hz}, 4 \mathrm{H}, \mathrm{CH}=\mathrm{CHCH}_{2} \mathrm{OH}\right), 5.22\left(\mathrm{~d}, J 12.4 \mathrm{~Hz}, 4 \mathrm{H}, \mathrm{CH}=\mathrm{CHCH}_{2} \mathrm{OH}\right.$ ), 4.30 (dd, J 6.2,

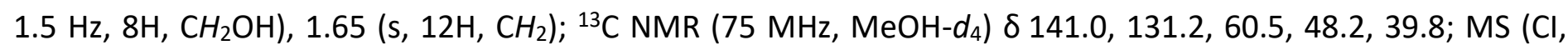
$\left.\mathrm{NH}_{3}\right) \mathrm{m} / \mathrm{z} 378\left(\mathrm{M}+\mathrm{NH}_{4}{ }^{+}\right)$. Anal. calc for $\mathrm{C}_{22} \mathrm{H}_{32} \mathrm{O}_{4}: \mathrm{C}, 76.44 ; \mathrm{H}, 7.90$. Found: $\mathrm{C}, 76.37 ; \mathrm{H}, 8.03$.

Methyl (Z)-3-(Adamantan-1-yl)acrylate (24). KN(TMS) $)_{2}$ in PhMe (0.5 M; $\left.7.32 \mathrm{~mL}, 3.66 \mathrm{mmol}\right)$ was added dropwise with stirring to 18-crown-6 $(4.83 \mathrm{~g}, 18.3 \mathrm{mmol})$ and bis(2,2,2-trifluoroethyl) (methoxycarbonylmethyl) phosphonate $(1.28 \mathrm{~g}, 4.02 \mathrm{mmol})$ in THF $(4 \mathrm{~mL})$ at $-78{ }^{\circ} \mathrm{C}$. After $30 \mathrm{~min}$, aldehyde 23 (300 mg, $1.83 \mathrm{mmol})$ in THF $(10 \mathrm{~mL})$ was added with stirring and, after further stirring at $-78^{\circ} \mathrm{C}$ for $1 \mathrm{~h}, 0{ }^{\circ} \mathrm{C}$ for $2 \mathrm{~h}$ and room temperature for $2 \mathrm{~h}$, reaction was quenched with saturated aqueous $\mathrm{NH}_{4} \mathrm{Cl}(20 \mathrm{~mL})$. The separated aqueous layer was extracted with EtOAc $(3 \times 25 \mathrm{~mL})$ and the combined organic layers were washed with brine $(30 \mathrm{~mL})$, dried $\left(\mathrm{MgSO}_{4}\right)$, concentrated in vacuo and the residue chromatographed (hexanes : EtOAc, $50: 1)$ to give the methyl ester $24^{46}(116 \mathrm{mg}, 30 \%)$ as a colorless oil: $R_{f} 0.46$ (hexanes : EtOAc, $\left.15: 1\right)$; IR (film) 2904, 2849, 1729, $1194 \mathrm{~cm}^{-1}$; ${ }^{1} \mathrm{H}$ NMR (300 MHz, CDCl 3 ) $\delta 5.78$ (d, J $13.2 \mathrm{~Hz}, 1 \mathrm{H}, \mathrm{CH}=\mathrm{CHCO}_{2} \mathrm{Me}$ ), 5.65 (d, J 13.2 $\left.\mathrm{Hz}, 1 \mathrm{H}, \mathrm{CH}=\mathrm{CHCO}_{2} \mathrm{Me}\right), 3.72\left(\mathrm{~s}, 3 \mathrm{H}, \mathrm{OCH}_{3}\right), 1.98$ (s, 3H, adamantane methine), $1.86(\mathrm{~d}, J 2.1 \mathrm{~Hz}, 6 \mathrm{H}, \mathrm{CH}$ ), 1.71 $\left(\mathrm{s}, 6 \mathrm{H}, \mathrm{CH}_{2}\right) ;{ }^{13} \mathrm{C} \mathrm{NMR}\left(75 \mathrm{MHz}, \mathrm{CDCl}_{3}\right) \delta 167.4,155.1,117.9,51.3,40.9,36.6,36.2,28.5 ; \mathrm{MS}(\mathrm{EI}) \mathrm{m} / \mathrm{z} 220\left(\mathrm{M}^{+}\right)$; HRMS (EI) $m / z$ calc for $\mathrm{C}_{14} \mathrm{H}_{20} \mathrm{O}_{2} 220.1463$, found: 220.1462 .

(Z)-3-(Adamantan-1-yl)prop-2-en-1-ol (25). DIBAl-H in hexanes (1.0 M; $1.16 \mathrm{~mL}, 1.16 \mathrm{mmol}$ ) was added dropwise with stirring to acrylate $24(102 \mathrm{mg}, 0.464 \mathrm{mmol})$ in $\mathrm{CH}_{2} \mathrm{Cl}_{2}(5 \mathrm{~mL})$ at $-78{ }^{\circ} \mathrm{C}$. After 40 min, reaction was quenched with saturated aqueous $\mathrm{NH}_{4} \mathrm{Cl}(2 \mathrm{~mL})$ and $4 \mathrm{M}$ aqueous $\mathrm{HCl}(1 \mathrm{~mL})$. The separated aqueous layer was extracted with EtOAc $(3 \times 10 \mathrm{~mL})$ and the combined organic layers were washed with saturated aqueous $\mathrm{NaHCO}_{3}(20 \mathrm{~mL})$ and brine $(20 \mathrm{~mL})$, dried $\left(\mathrm{MgSO}_{4}\right)$, concentrated in vacuo and the residue chromatographed (hexanes: EtOAc, $4: 1)$ to give the allylic alcohol $25(79 \mathrm{mg}, 90 \%)$ as a colorless oil, which was used directly crude in the next step: $R_{f} 0.58$ (hexanes : EtOAc, $2: 1$ ); IR (film) 3560, 2920, $2854 \mathrm{~cm}^{-1} ;{ }^{1} \mathrm{H} \mathrm{NMR}(300 \mathrm{MHz}$, $\left.\mathrm{CDCl}_{3}\right) \delta 5.35\left(\mathrm{dt}, J 12.3,6.2 \mathrm{~Hz}, 1 \mathrm{H}, \mathrm{CH}=\mathrm{CHCH} \mathrm{OH}_{2}, 5.17\left(\mathrm{~d}, J 12.3 \mathrm{~Hz}, 1 \mathrm{H}, \mathrm{CH}=\mathrm{CHCH}_{2} \mathrm{OH}\right), 4.33(\mathrm{~d}, J 6.2 \mathrm{~Hz}, 2 \mathrm{H}\right.$, $\left.\mathrm{CH}_{2} \mathrm{OH}\right), 1.95\left(\mathrm{~s}, 3 \mathrm{H}\right.$, adamantane methine), $1.84\left(\mathrm{~s}, 1 \mathrm{H}, \mathrm{CH}_{2} \mathrm{OH}\right), 1.72\left(\mathrm{~s}, 6 \mathrm{H}, \mathrm{CH}_{2}\right), 1.68\left(\mathrm{~s}, 6 \mathrm{H}, \mathrm{CH}_{2}\right) ;{ }^{13} \mathrm{C} \mathrm{NMR}$ $\left(75 \mathrm{MHz} \mathrm{CDCl}_{3}\right) \delta$ 142.0, 127.4, 59.5, 42.8, 36.6, 35.9, 28.5.

((1R,2S)-2-(Adamantan-1-yl)cyclopropyl)methanol (27). $\mathrm{CH}_{2} \mathrm{Cl}_{2}(3 \mathrm{~mL})$ and 1,2-dimethoxyethane $(0.182 \mathrm{~mL}$, $1.75 \mathrm{mmol})$ in a flame-dried flask were cooled to $-15^{\circ} \mathrm{C}$ and neat $\mathrm{Et}_{2} \mathrm{Zn}(0.179 \mathrm{~mL}, 1.75 \mathrm{mmol})$ was added with stirring. $\mathrm{CH}_{2} \mathrm{I}_{2}(0.282 \mathrm{~mL}, 3.50 \mathrm{mmol})$ was added slowly with stirring keeping the internal temperature below $-10{ }^{\circ} \mathrm{C}$. After $10 \mathrm{~min}$ at $-10{ }^{\circ} \mathrm{C}$, dioxaborolane $26(189 \mathrm{mg}, 0.70 \mathrm{mmol})$ in $\mathrm{CH}_{2} \mathrm{Cl}_{2}(2 \mathrm{~mL})$ was added slowly with stirring while maintaining the internal temperature below $-5{ }^{\circ} \mathrm{C}$. Allylic alcohol $25(112 \mathrm{mg}, 0.583 \mathrm{mmol})$ in $\mathrm{CH}_{2} \mathrm{Cl}_{2}(2 \mathrm{~mL})$ was immediately added to the solution and the mixture allowed to reach and react further at room temperature. After $5 \mathrm{~h}$, reaction was quenched with saturated aqueous $\mathrm{NH}_{4} \mathrm{Cl}(10 \mathrm{~mL})$, the separated aqueous layer was extracted with $\mathrm{CH}_{2} \mathrm{Cl}_{2}(3 \times 10 \mathrm{~mL})$, and the combined organic layers were washed with brine $(20 \mathrm{~mL})$, dried $\left(\mathrm{MgSO}_{4}\right)$, concentrated in vacuo and the residue chromatographed (hexanes : EtOAc, $7: 1 \rightarrow 6:$ 1) to give the cyclopropane $27(104 \mathrm{mg}, 87 \%)$ as colorless needle crystals: $\mathrm{mp} 88-90{ }^{\circ} \mathrm{C}$ (hexanes : EtOAc, 2 : 
1); $R_{f} 0.57$ (hexanes: EtOAc, $\left.2: 1\right)$; IR (film) 3271 broad, 2891, 2847, $1447 \mathrm{~cm}^{-1} ;{ }^{1} \mathrm{H} \mathrm{NMR}(300 \mathrm{MHz}, \mathrm{CDCl} 3) \delta$ $3.74\left(\mathrm{~m}, 2 \mathrm{H}, \mathrm{CH}_{2} \mathrm{OH}\right), 1.94(\mathrm{~s}, 3 \mathrm{H}$, adamantane methine), 1.60-1.71 (m, 6H, adamantane methylene), 1.53 (s, $6 \mathrm{H}$, adamantane methylene), 0.98-1.11 (m, $\left.1 \mathrm{H}, \mathrm{CHCH}_{2} \mathrm{OH}\right), 0.59\left(\mathrm{~m}, 2 \mathrm{H}\right.$, cyclopropane $\left.\mathrm{CH}_{2}\right), 0.25(\mathrm{~m}, 1 \mathrm{H}$, cyclopropane $\mathrm{CH}) ;{ }^{13} \mathrm{C} \mathrm{NMR}\left(75 \mathrm{MHz}, \mathrm{CDCl}_{3}\right) \delta$ 63.6, 43.2, 37.0, 32.3, 29.7, 28.8, 19.8, 4.5; $\mathrm{MS}\left(\mathrm{Cl}, \mathrm{NH}_{3}\right) \mathrm{m} / z 224$ $\left(\mathrm{M}+\mathrm{NH}_{4}^{+}\right) ; \mathrm{HRMS}\left(\mathrm{Cl}, \mathrm{NH}_{3}\right) \mathrm{m} / z$ calc for $\mathrm{C}_{14} \mathrm{H}_{26} \mathrm{NO}\left(\mathrm{M}+\mathrm{NH}_{4}^{+}\right)$224.2014, found: 224.2022 .

(1R,2S)-2-(Adamantan-1-yl)cyclopropane-1-carboxaldehyde (28). Dess-Martin periodinane (268 mg, 0.631 mmol) was added with stirring to alcohol $27(100 \mathrm{mg}, 0.485 \mathrm{mmol})$ in $\mathrm{CH}_{2} \mathrm{Cl}_{2}(5 \mathrm{~mL})$. After $1.2 \mathrm{~h}$ at room temperature, reaction was quenched with saturated aqueous $\mathrm{NaHCO}_{3}(3 \mathrm{~mL})$ and saturated aqueous $\mathrm{Na}_{2} \mathrm{~S}_{2} \mathrm{O}_{3}$ $(3 \mathrm{~mL})$. The mixture was extracted with $\mathrm{CH}_{2} \mathrm{Cl}_{2}(3 \times 10 \mathrm{~mL})$ and the combined organic extracts were washed with brine $(20 \mathrm{~mL})$, dried $\left(\mathrm{MgSO}_{4}\right)$, concentrated in vacuo and chromatographed (hexanes : EtOAc, $\left.14: 1\right)$ to afford the aldehyde 28 (71 mg, 72\%) as a colorless oil: $R_{f} 0.68$ (hexanes : EtOAc, $4: 1$ ); IR (film) 2902, 2847, $1698 \mathrm{~cm}^{-1} ;{ }^{1} \mathrm{H}$ NMR (300 MHz, CDCl 3 ) $\delta 9.29$ (d, J $\left.7.2 \mathrm{~Hz}, 1 \mathrm{H}, \mathrm{CHO}\right), 1.97$ (s, 3H, adamantane methine), 1.59$1.76(\mathrm{~m}, 6 \mathrm{H}$, adamantane methylene), $1.53(\mathrm{~s}, 6 \mathrm{H}$, adamantane methylene), 1.16-1.35 (m, 4H, cyclopropane); ${ }^{13} \mathrm{C} \mathrm{NMR}\left(75 \mathrm{MHz}, \mathrm{CDCl}_{3}\right.$ ) $\delta$ 200.9, 43.2, 38.0, 36.6, 32.4, 30.2, 28.5, 9.9; MS (EI) $\mathrm{m} / z 204$ (M ${ }^{+\cdot}$ ); HRMS (EI) $\mathrm{m} / z$ calc for $\mathrm{C}_{14} \mathrm{H}_{20} \mathrm{O}\left(\mathrm{M}^{+}\right)$204.1514, found: 204.1521 .

\section{(2Z,2'Z,2'Z)-3,3',3'-(7-((Z)-3-((tert-Butyldiphenylsilyl)oxy)prop-1-en-1-yl)adamantane-1,3,5-triyl)tris(prop-2-} en-1-ol) (29). DMAP (30 mg, $0.241 \mathrm{mmol}$ ) and ${ }^{\mathrm{t}} \mathrm{BuPh}{ }_{2} \mathrm{SiCl}(0.173 \mathrm{~mL}, 0.663 \mathrm{mmol})$ were added with stirring to tetra-allylic alcohol $21(217 \mathrm{mg}, 0.603 \mathrm{mmol})$ in dry pyridine $(5 \mathrm{~mL})$. After $41 \mathrm{~h}$ at room temperature, reaction was quenched with saturated aqueous $\mathrm{NH}_{4} \mathrm{Cl}(3 \mathrm{~mL})$ and the aqueous layer was extracted with $\mathrm{CH}_{2} \mathrm{Cl}_{2} / i-\mathrm{PrOH}$ (4:1) $(4 \times 10 \mathrm{~mL})$. The combined organic layers were dried $\left(\mathrm{MgSO}_{4}\right)$, concentrated in vacuo, and chromatographed $\left(\mathrm{CH}_{2} \mathrm{Cl}_{2}: \mathrm{MeOH}, 16: 1\right.$ to $\left.12: 1\right)$ to give recovered tetra-allylic alcohol $21(71 \mathrm{mg}, 33 \%)$ and the mono-silylated product 29 (160 mg, 44\%) as a thick oil: $R_{f} 0.48\left(\mathrm{CH}_{2} \mathrm{Cl}_{2}: \mathrm{MeOH}, 8: 1\right)$; IR (film) 3350, 2928, $2855 \mathrm{~cm}^{-1}$; ${ }^{1} \mathrm{H}$ NMR $\left(300 \mathrm{MHz}, \mathrm{CDCl}_{3}\right) \delta 7.69(\mathrm{~d}, \mathrm{~J} 7.2 \mathrm{~Hz}, 4 \mathrm{H}, \mathrm{ArH}), 7.42(\mathrm{~m}, 6 \mathrm{H}, \mathrm{ArH}), 5.50(\mathrm{dt}, J 12.3,5.8 \mathrm{~Hz}, 1 \mathrm{H}$, $\mathrm{CH}=\mathrm{CHCH}_{2} \mathrm{OSi}$ ), 5.39 (dt, J 12.2, $\left.6.0 \mathrm{~Hz}, 3 \mathrm{H}, \mathrm{CH}=\mathrm{CHCH}_{2} \mathrm{OH}\right), 5.15\left(\mathrm{~d}, J 12.2 \mathrm{~Hz}, 3 \mathrm{H}, \mathrm{CH}=\mathrm{CHCH}_{2} \mathrm{OH}\right), 5.10$ (d, J 12.3 $\mathrm{Hz}, 1 \mathrm{H}, \mathrm{CH}=\mathrm{CHCH}_{2} \mathrm{OSi}$ ), 4.37 (d, J $\left.6.0 \mathrm{~Hz}, 6 \mathrm{H}, \mathrm{CH}=\mathrm{CHCH}_{2} \mathrm{OH}\right), 4.20$ (d, J $\left.5.8 \mathrm{~Hz}, 2 \mathrm{H}, \mathrm{CH}=\mathrm{CHCH}_{2} \mathrm{OSi}\right), 1.73(\mathrm{~s}, 3 \mathrm{H}$, $\left.\mathrm{CH}=\mathrm{CHCH}_{2} \mathrm{OH}\right), 1.52(\mathrm{~m}, 6 \mathrm{H}$, adamantane methylene), $1.44(\mathrm{~s}, 6 \mathrm{H}$, adamantane methylene), $1.05(\mathrm{~s}, 9 \mathrm{H}$, tertbutyl); ${ }^{13} \mathrm{C} \mathrm{NMR}\left(75 \mathrm{MHz}, \mathrm{CDCl}_{3}\right) \delta 140.0,137.9,135.6,133.7,129.7,129.4,128.4,127.7,60.9,59.3,46.0,45.9$, $37.6,29.7,26.7,19.1$; the product did not exhibit a molecular ion in the MS.

\section{(Z)-tert-Butyldiphenyl((3-(3,5,7-tri-(1R,2S)-2-hydroxymethyl-1-cyclopropyl)-adamantan-1-yl)allyl)oxy)silane}

(30). $\mathrm{CH}_{2} \mathrm{Cl}_{2}(8 \mathrm{~mL})$ and 1,2-dimethoxyethane $(0.64 \mathrm{~mL}, 6.17 \mathrm{mmol})$ in a flame-dried flask were cooled to -15 ${ }^{\circ} \mathrm{C}$ and neat $\mathrm{Et}_{2} \mathrm{Zn}(0.63 \mathrm{~mL}, 6.17 \mathrm{mmol})$ was added with stirring. $\mathrm{CH}_{2} \mathrm{I}_{2}(0.99 \mathrm{~mL}, 12.3 \mathrm{mmol})$ was added slowly with stirring keeping the internal temperature below $-10{ }^{\circ} \mathrm{C}$. After $10 \mathrm{~min}$ at $-10{ }^{\circ} \mathrm{C}$, dioxaborolane 26 (500 mg, $1.85 \mathrm{mmol}$ ) in $\mathrm{CH}_{2} \mathrm{Cl}_{2}(3 \mathrm{~mL})$ was added slowly with stirring while maintaining the internal temperature below $-5{ }^{\circ} \mathrm{C}$. Allylic alcohol 29 (308 mg, $0.514 \mathrm{mmol}$ ) in $\mathrm{CH}_{2} \mathrm{Cl}_{2}(4 \mathrm{~mL})$ was immediately added to the solution and the mixture allowed to reach and react further at room temperature. After $4 \mathrm{~h}$, reaction was quenched with saturated aqueous $\mathrm{NH}_{4} \mathrm{Cl}(8 \mathrm{~mL})$ and the aqueous layer was extracted with $\mathrm{CH}_{2} \mathrm{Cl}_{2} / \mathrm{MeOH}(7: 1)$ $(4 \times 10 \mathrm{~mL})$. The combined organic layers were washed with brine $(20 \mathrm{~mL})$, dried $\left(\mathrm{MgSO}_{4}\right)$, concentrated in vacuo, and the residue chromatographed (hexanes : EtOAc : MeOH, $1: 1: 0.03$ to $1: 1: 0.05$ ) to give the tricyclopropane 30 (295 mg, 90\%) as a colorless oil: $R_{f} 0.40$ (hexanes: EtOAc: MeOH, $1: 1: 0.2$ ); $[\alpha]_{D} 22-15.3(c$ 0.96, $\mathrm{CHCl}_{3}$ ); IR (film) 3366 (br), 2928, 2895, 2855, $1427 \mathrm{~cm}^{-1} ;{ }^{1} \mathrm{H} \mathrm{NMR}\left(300 \mathrm{MHz}, \mathrm{CDCl}_{3}\right) \delta 7.70(\mathrm{~d}, J 7.3 \mathrm{~Hz}, 4 \mathrm{H}$, $\mathrm{ArH}), 7.41(\mathrm{~m}, 6 \mathrm{H}, \mathrm{ArH}), 5.48\left(\mathrm{dt}, J 12.4,5.5 \mathrm{~Hz}, 1 \mathrm{H}, \mathrm{CH}=\mathrm{CHCH}_{2} \mathrm{OSi}\right), 5.12\left(\mathrm{~d}, J 12.4 \mathrm{~Hz}, 1 \mathrm{H}, \mathrm{CH}=\mathrm{CHCH}_{2} \mathrm{OSi}\right), 4.37$ 
(d, J $5.5 \mathrm{~Hz}, 2 \mathrm{H}, \mathrm{CH}=\mathrm{CHCH}_{2} \mathrm{OSi}$ ), 3.78 (dd, J 11.0, $7.5 \mathrm{~Hz}, 3 \mathrm{H}, \mathrm{CH}_{2} \mathrm{OH}$ ), 3.50 (dd, J 11.0, 8.6 Hz, 3H, $\mathrm{CH}_{2} \mathrm{OH}$ ), 2.03 $\left(\mathrm{s}, 3 \mathrm{H}, \mathrm{CH}_{2} \mathrm{OH}\right), 1.24(\mathrm{~s}, 6 \mathrm{H}$, adamantane methylene), $1.17(\mathrm{~s}, 6 \mathrm{H}$, adamantane methylene), $1.05(\mathrm{~s}, 9 \mathrm{H}$, tert-butyl), $1.00(\mathrm{~m}, 3 \mathrm{H}$, cyclopropane methine), $0.55(\mathrm{~m}, 6 \mathrm{H}$, cyclopropane methylene), $0.16(\mathrm{~m}, 3 \mathrm{H}$, cyclopropane methine); ${ }^{13} \mathrm{C}$ NMR $\left(75 \mathrm{MHz}, \mathrm{CDCl}_{3}\right) \delta 138.8,135.6,133.8,129.6,128.8,127.6,63.3,61.1,46.9$, 46.7, 37.8, 34.2, 28.9, 26.7, 19.2, 19.1, 4.6; $\mathrm{MS}\left(\mathrm{Cl}, \mathrm{NH}_{3}\right) \mathrm{m} / \mathrm{z} 658\left(\mathrm{M}+\mathrm{NH}_{4}^{+}\right)$. Anal. calc for $\mathrm{C}_{41} \mathrm{H}_{56} \mathrm{O}_{4} \mathrm{Si}: \mathrm{C}, 76.83$; $H, 8.81$. Found: $C, 76.77 ; H, 8.90$.

\section{1-((1Z)-3-Hydroxy-1-propenyl))-((3-(3,5,7-tri-(1R,2S)-2-hydroxymethyl-1-cyclopropyl)adamantane}

(31).

$\mathrm{Bu}_{4} \mathrm{NF}$ in THF (1.0 M; $\left.0.233 \mathrm{~mL}, 0.233 \mathrm{mmol}\right)$ was added with stirring to allylic alcohol 30 (136 mg, $\left.0.212 \mathrm{mmol}\right)$ in THF ( $3 \mathrm{~mL})$ at room temperature. After $24 \mathrm{~h}$, reaction was quenched with $\mathrm{H}_{2} \mathrm{O}(2 \mathrm{~mL})$ and the separated aqueous layer was extracted with $\mathrm{CH}_{2} \mathrm{Cl}_{2} /$ i-PrOH (4:1) $(4 \times 5 \mathrm{~mL})$. The combined organic layers were washed with brine $(10 \mathrm{~mL})$, dried $\left(\mathrm{MgSO}_{4}\right)$, concentrated in vacuo, and the residue chromatographed (hexanes : EtOAc : MeOH, $1: 1: 0.2)$ to give the free allylic alcohol 31 (79 mg, 94\%) as a colorless oil: $R_{f} 0.32\left(\mathrm{CH}_{2} \mathrm{Cl}_{2}: \mathrm{MeOH}, 8:\right.$ 1); $[\alpha]_{D}{ }^{22}-16.2$ (c 1.03, MeOH); IR (film) 3345 (br), 2995, $2895 \mathrm{~cm}^{-1} ;{ }^{1} \mathrm{H}$ NMR $\left(300 \mathrm{MHz}, \mathrm{CDCl}_{3}\right) \delta 5.33(\mathrm{dt}, J$ 12.4, $\left.6.0 \mathrm{~Hz}, 1 \mathrm{H}, \mathrm{CH}=\mathrm{CHCH}_{2} \mathrm{OH}\right), 5.17\left(\mathrm{~d}, J 12.4 \mathrm{~Hz}, 1 \mathrm{H}, \mathrm{CH}=\mathrm{CHCH}_{2} \mathrm{OH}\right.$ ), 4.26 (dd, J 6.0, $1.4 \mathrm{~Hz}, 2 \mathrm{H}$, $\left.\mathrm{CH}=\mathrm{CHCH}_{2} \mathrm{OH}\right), 3.75-3.62\left(\mathrm{~m}, 6 \mathrm{H}\right.$, cyclopropyl $\left.\mathrm{CH}_{2} \mathrm{OH}\right), 1.41(\mathrm{~s}, 6 \mathrm{H}$, adamantane methylene), $1.27(\mathrm{~s}, 6 \mathrm{H}$, adamantane methylene), $1.03(\mathrm{~m}, 3 \mathrm{H}$, cyclopropane), 0.67-0.60 (m, 6H, cyclopropane), $0.26(\mathrm{~m}, 3 \mathrm{H}$, cyclopropane); ${ }^{13} \mathrm{C}$ NMR (75 MHz, $\mathrm{CDCl}_{3}$ ) $\delta 141.9,130.6,64.6,60.7,49.3,40.1,36.5,31.0,21.3,6.4$; the product did not exhibit a molecular ion in the MS.

\section{(Z)-tert-Butyldiphenyl((3-(3,5,7-tri-(1R,2S)-2-(pivaloyloxymethyl)-1-cyclopropyl)-adamantan-1-}

yl)allyl)oxy)silane (32). $\mathrm{Me}_{3} \mathrm{CCOCl}(0.233 \mathrm{~mL}, 1.89 \mathrm{mmol})$ was added with stirring to triol 30 (121 mg, $0.189 \mathrm{mmol})$ in dry pyridine $(4 \mathrm{~mL})$ at room temperature. After $2 \mathrm{~h}$, reaction was quenched with saturated aqueous $\mathrm{NH}_{4} \mathrm{Cl}(4 \mathrm{~mL})$ and the separated aqueous layer was extracted with $\mathrm{CH}_{2} \mathrm{Cl}_{2}(3 \times 10 \mathrm{~mL})$. The combined organic layers were washed with brine $(15 \mathrm{~mL})$, dried $\left(\mathrm{MgSO}_{4}\right)$, concentrated in vacuo, and the residue chromatographed (hexanes: EtOAc, $25: 1$ to $20: 1)$ to give the tri-pivaloate $32(160 \mathrm{mg}, 95 \%)$ as a colorless thick oil: $R_{f} 0.32$ (hexanes : EtOAc, $10: 1$ ); $[\alpha]_{\mathrm{D}}{ }^{22}-24.5$ (c 1.02, $\mathrm{CHCl}_{3}$ ); IR (film) 3069, 2967, 2932, $1726 \mathrm{~cm}^{-1} ;{ }^{1} \mathrm{H}$ NMR $\left(300 \mathrm{MHz}, \mathrm{CDCl}_{3}\right) \delta 7.68(\mathrm{~d}, J 7.1 \mathrm{~Hz}, 4 \mathrm{H}, \mathrm{ArH}), 7.39(\mathrm{~m}, 6 \mathrm{H}, \mathrm{ArH}), 5.45(\mathrm{dt}, J 12.4,5.6 \mathrm{~Hz}, 1 \mathrm{H}$, $\mathrm{CH}=\mathrm{CHCH}_{2} \mathrm{OSi}$ ), 5.05 (d, J $\left.12.4 \mathrm{~Hz}, 1 \mathrm{H}, \mathrm{CH}=\mathrm{CHCH}_{2} \mathrm{OSi}\right), 4.42-4.36\left(\mathrm{~m}, 5 \mathrm{H}, \mathrm{CH}=\mathrm{CHCH}_{2} \mathrm{OSi}\right.$ and $\left.\mathrm{CH}_{2} \mathrm{OPiv}\right), 3.83$ (dd, J 11.1, $\left.9.0 \mathrm{~Hz}, 3 \mathrm{H}, \mathrm{CH}_{2} \mathrm{OPiv}\right), 1.24\left(\mathrm{~m}, 12 \mathrm{H}\right.$, adamantane methylene), 1.21-1.16 (m, 30H, $\mathrm{COC}\left(\mathrm{CH}_{3}\right)_{3}$ and cyclopropane methine), $1.05\left(\mathrm{~s}, 9 \mathrm{H}, \mathrm{SiC}\left(\mathrm{CH}_{3}\right)_{3}\right), 0.57(\mathrm{~m}, 6 \mathrm{H}$, cyclopropane methylene), $0.19(\mathrm{~m}, 3 \mathrm{H}$, cyclopropane methine); ${ }^{13} \mathrm{C} \mathrm{NMR}\left(75 \mathrm{MHz} \mathrm{CDCl}_{3}\right) \delta 178.5,138.4,135.5,133.7,129.6,128.8,127.6,65.6,61.0$, $46.9,46.4,38.6,38.0,34.2,28.8,27.3,26.8,19.1,15.5,4.7$; the product did not exhibit a molecular ion in the MS.

1-((1Z)-3-Hydroxy-1-propenyl)-((3-(3,5,7-tri-(1R,2S)-2-(pivaloyloxymethyl)-1-cyclopropyl)adamantane (33). $\mathrm{Bu}_{4} \mathrm{NF}$ in THF $(1.0 \mathrm{M} ; 0.086 \mathrm{~mL}, 0.086 \mathrm{mmol})$ was added dropwise with stirring to silyl ether 32 (70 mg, $0.078 \mathrm{mmol})$ in THF $(2 \mathrm{~mL})$ at room temperature. After $16 \mathrm{~h}$, reaction was quenched with $\mathrm{H}_{2} \mathrm{O}(2 \mathrm{~mL})$ and the separated aqueous layer was extracted with $\mathrm{CH}_{2} \mathrm{Cl}_{2}(3 \times 6 \mathrm{~mL})$. The combined organic layers were washed with brine, dried $\left(\mathrm{MgSO}_{4}\right)$, and concentrated in vacuo, and the residue chromatographed (hexanes : EtOAc, $7: 1$ to $4: 1)$ to give the allylic alcohol $33(49 \mathrm{mg}, 95 \%)$ as a colorless thick oil: $R_{f} 0.15$ (hexanes : EtOAc, $\left.4: 1\right) ;[\alpha]_{\mathrm{D}}^{22}$ -31.2 (c 1.60, $\mathrm{CHCl}_{3}$ ); IR (film) 3516 broad, 2971, 2906, 1726, 1480, $1283 \mathrm{~cm}^{-1} ;{ }^{1} \mathrm{H} \mathrm{NMR}\left(300 \mathrm{MHz}, \mathrm{CDCl}_{3}\right) \delta 5.39$ (dt, J 12.3, $6.5 \mathrm{~Hz}, 1 \mathrm{H}, \mathrm{CH}=\mathrm{CHCH}_{2} \mathrm{OH}$ ), 5.17 (d, J $12.3 \mathrm{~Hz}, 1 \mathrm{H}, \mathrm{CH}=\mathrm{CHCH}_{2} \mathrm{OH}$ ), 4.44 (dd, J 11.5, 7.5 Hz, 3H, $\mathrm{CH}_{2} \mathrm{OPiv}$ ), 4.26 (d, J $6.5 \mathrm{~Hz}, 2 \mathrm{H}, \mathrm{CH}=\mathrm{CHCH}_{2} \mathrm{OH}$ ), 3.92 (dd, J 11.5, 8.9 Hz, 3H, CH 
methylene), 1.31-1.29 (m, 6H, adamantane methylene), $1.22\left(\mathrm{~s}, 27 \mathrm{H}, \mathrm{COC}\left(\mathrm{CH}_{3}\right)_{3}\right), 1.11(\mathrm{~m}, 3 \mathrm{H}$, cyclopropane methine), $0.64\left(\mathrm{~m}, 6 \mathrm{H}\right.$, cyclopropane methylene), $0.27\left(\mathrm{~m}, 3 \mathrm{H}\right.$, cyclopropane methine); ${ }^{13} \mathrm{C} \mathrm{NMR} \mathrm{(75} \mathrm{MHz,}$ $\left.\mathrm{CDCl}_{3}\right) \delta 178.7,140.3,128.2,65.7,59.2,47.3,46.3,38.7,37.8,34.3,28.9,27.3,15.5,4.7$; the product did not exhibit a molecular ion in the MS.

\section{1-((1R,2S)-2-(Hydroxymethyl)-1-cyclopropyl)-3,5,7-tri-((1R,2S)-2-(pivaloyloxymethyl)-1-}

cyclopropyl)adamantane (34). $\mathrm{CH}_{2} \mathrm{Cl}_{2}(4 \mathrm{~mL})$ and 1,2-dimethoxyethane $(0.196 \mathrm{~mL}, 1.89 \mathrm{mmol})$ in a flame-dried flask were cooled to $-15{ }^{\circ} \mathrm{C}$ and neat $\mathrm{Et}_{2} \mathrm{Zn}(0.193 \mathrm{~mL}, 1.89 \mathrm{mmol})$ was added with stirring. $\mathrm{CH}_{2} \mathrm{I}_{2}(0.304 \mathrm{~mL}$, $3.77 \mathrm{mmol}$ ) was added slowly with stirring keeping the internal temperature below $-10{ }^{\circ} \mathrm{C}$. After $10 \mathrm{~min}$ at $-10{ }^{\circ} \mathrm{C}$, dioxaborolane ligand 26 (153 mg, $\left.0.566 \mathrm{mmol}\right)$ in $\mathrm{CH}_{2} \mathrm{Cl}_{2}(1 \mathrm{~mL})$ was added slowly with stirring while maintaining the internal temperature below $-5{ }^{\circ} \mathrm{C}$. An aliquot $(2 \mathrm{~mL})$ of this cold solution was immediately added with stirring to allylic alcohol 33 (103 mg, $0.157 \mathrm{mmol}$ ) in $\mathrm{CH}_{2} \mathrm{Cl}_{2}(1 \mathrm{~mL})$ at $-10{ }^{\circ} \mathrm{C}$ and the mixture allowed to warm up to room temperature. After $5 \mathrm{~h}$, reaction was quenched with saturated aqueous $\mathrm{NH}_{4} \mathrm{Cl}(2$ $\mathrm{mL}$ ) and the separated aqueous layer was extracted with $\mathrm{CH}_{2} \mathrm{Cl}_{2} / \mathrm{MeOH}(6: 1)(4 \times 5 \mathrm{~mL})$. The combined organic layers were washed with brine $(10 \mathrm{~mL})$, dried $\left(\mathrm{MgSO}_{4}\right)$, concentrated in vacuo, and the residue chromatographed (hexanes : EtOAc, $15: 1$ to $12: 1$ ) to give the tetracyclopropyl adamantane 34 (66 mg, $63 \%$ ) as a colorless oil: $R_{f} 0.24$ (hexanes: EtOAc, $4: 1$ ); $[\alpha]_{D}^{22}-25.3$ (c 1.02, $\mathrm{CHCl}_{3}$ ); IR (film) 3524 (br), 2969, 1726, $1152 \mathrm{~cm}^{-1}$; ${ }^{1} \mathrm{H}$ NMR (300 MHz, $\mathrm{CDCl}_{3}$ ) $\delta 4.40$ (m, 3H, $\left.\mathrm{CH}_{2} \mathrm{OPiv}\right), 3.92$ (m, 3H, CH $\mathrm{CH}_{2} \mathrm{OPiv}$ ), 3.82 (dd, J 10.8, 7.3 Hz, $\left.1 \mathrm{H}, \mathrm{CH}_{2} \mathrm{OH}\right), 3.60\left(\mathrm{dd}, J 10.8,7.9 \mathrm{~Hz}, 1 \mathrm{H}, \mathrm{CH}_{2} \mathrm{OH}\right), 1.39-1.09\left(\mathrm{~m}, 42 \mathrm{H}\right.$, adamantane methylene and $\mathrm{COC}\left(\mathrm{CH}_{3}\right)_{3}$ and $\left.\mathrm{CHCH}_{2} \mathrm{OPiv}\right), 0.87\left(\mathrm{~m}, 1 \mathrm{H}, \mathrm{CHCH}_{2} \mathrm{OH}\right), 0.64-0.60(\mathrm{~m}, 8 \mathrm{H}$, cyclopropane methylene), 0.27-0.21 (m, 4H, cyclopropane methine); ${ }^{13} \mathrm{C} \mathrm{NMR}\left(75 \mathrm{MHz}, \mathrm{CDCl}_{3}\right) \delta 178.6,65.7,63.3,47.7,46.6,38.7,34.3,28.9,27.3,19.4$, 15.5, 4.7; $\mathrm{MS}\left(\mathrm{Cl}, \mathrm{NH}_{3}\right) \mathrm{m} / z 686\left(\mathrm{M}+\mathrm{NH}_{4}{ }^{+}\right)$; $\mathrm{HRMS}\left(\mathrm{Cl}, \mathrm{NH}_{3}\right) m / z$ calc for $\mathrm{C}_{41} \mathrm{H}_{68} \mathrm{NO}_{7}\left(\mathrm{M}+\mathrm{NH}_{4}{ }^{+}\right)$686.4996, found: 686.5004 .

1,3,5,7-Tetra-((1R,2S)-2-(hydroxymethyl)-1-cyclopropyl)adamantane (35). DIBAl-H in hexanes (1.0 M; 0.706 $\mathrm{mL}, 0.706 \mathrm{mmol}$ ) was added dropwise with stirring over $5 \mathrm{~min}$ to tri-pivaloate 34 (63 $\mathrm{mg}, 0.094 \mathrm{mmol})$ in $\mathrm{CH}_{2} \mathrm{Cl}_{2}(3.5 \mathrm{~mL})$ at $-78{ }^{\circ} \mathrm{C}$. After $1 \mathrm{~h}$ at $-78{ }^{\circ} \mathrm{C}$, saturated aqueous $\mathrm{NH}_{4} \mathrm{Cl}(0.14 \mathrm{~mL}), i$-PrOH $(4 \mathrm{~mL})$, silica gel $(200$ $\mathrm{mg}$ ) and Celite $(200 \mathrm{mg}$ ) were added. The mixture was allowed to warm to room temperature and filtered, and the solids were washed with $\mathrm{CH}_{2} \mathrm{Cl}_{2} / \mathrm{MeOH}(4: 1)$. Rotary evaporation of the combined organic layers and chromatography $\left(\mathrm{CH}_{2} \mathrm{Cl}_{2}: \mathrm{MeOH}, 16: 1\right.$ to $\left.12: 1\right)$ gave the tetra-syn-cyclopropyl alcohol 35 (35 mg, $\left.89 \%\right)$ as a viscous oil. Colorless crystals of tetra-syn-cyclopropyl alcohol $\mathbf{3 5}$ were obtained by crystallization from $\mathrm{MeOH} / \mathrm{PhMe} / \mathrm{THF}(1: 1: 1): \mathrm{mp} 168-170{ }^{\circ} \mathrm{C}$ (MeOH : PhMe:THF, $\left.1: 1: 1\right) ; R_{f} 0.32\left(\mathrm{CH}_{2} \mathrm{Cl}_{2}: \mathrm{MeOH}, 8: 1\right)$; $[\alpha]_{\mathrm{D}}{ }^{25}-17.6$ (c 1.0, MeOH); IR (film) 3321 (br), 2894, $2360 \mathrm{~cm}^{-1} ;{ }^{1} \mathrm{H}$ NMR $\left(300 \mathrm{MHz}, \mathrm{MeOH}-d_{4}\right) \delta 3.72(\mathrm{~m}, 8 \mathrm{H}$, $\left.\mathrm{CH}_{2} \mathrm{OH}\right), 1.27(\mathrm{~s}, 12 \mathrm{H}$, adamantane methylene), $1.03(\mathrm{~m}, 4 \mathrm{H}$, cyclopropane methine), 0.70-0.63 (m, 8H, cyclopropane methylene), 0.29 (d, J $3.4 \mathrm{~Hz}, 4 \mathrm{H}$, cyclopropane methine); ${ }^{13} \mathrm{C} \mathrm{NMR}\left(75 \mathrm{MHz}, \mathrm{MeOH}-d_{4}\right) \delta 64.6$, 49.6, 36.6, 31.0, 21.2, 6.4; $\mathrm{MS}\left(\mathrm{Cl}, \mathrm{NH}_{3}\right) \mathrm{m} / \mathrm{z} 434\left(\mathrm{M}+\mathrm{NH}_{4}^{+}\right)$.

1,3,5,7-Tetra-((1R,2S)-2-(formyl)-1-cyclopropyl)adamantane (14). DMSO (32 $\mu \mathrm{L}, 0.448 \mathrm{mmol}$ ) was added slowly with vigorous stirring to $(\mathrm{COCl})_{2}(19 \mu \mathrm{L}, 0.224 \mathrm{mmol})$ in $\mathrm{CH}_{2} \mathrm{Cl}_{2}(1 \mathrm{~mL})$ at $-78{ }^{\circ} \mathrm{C}$. After a further $15 \mathrm{~min}$ at $-78{ }^{\circ} \mathrm{C}$, tetra-alcohol 35 (11 $\left.\mathrm{mg}, 0.0264 \mathrm{mmol}\right)$ in DMSO $(0.3 \mathrm{~mL})$ and $\mathrm{CH}_{2} \mathrm{Cl}_{2}(0.6 \mathrm{~mL})$ was added slowly, and the reaction mixture was stirred at $-78{ }^{\circ} \mathrm{C}$ for an additional $1 \mathrm{~h}$. $\mathrm{Et}_{3} \mathrm{~N}(0.15 \mathrm{~mL})$ was added dropwise, and the mixture was allowed to warm up to room temperature. $\mathrm{H}_{2} \mathrm{O}(5 \mathrm{~mL})$ and $\mathrm{CH}_{2} \mathrm{Cl}_{2}(5 \mathrm{~mL})$ were added and the two phases were separated. The organic phase was washed with $5 \%$ aqueous $\mathrm{HCl}(2 \mathrm{~mL}), \mathrm{H}_{2} \mathrm{O}(2 \mathrm{~mL}), 5 \%$ aqueous $\mathrm{NaHCO}_{3}(4 \mathrm{~mL})$ and brine $(4 \mathrm{~mL})$, dried $\left(\mathrm{MgSO}_{4}\right)$, concentrated in vacuo and the residue chromatographed 
(hexanes: EtOAc: $\mathrm{MeOH}, 1: 1: 0.04)$ to afford the tetra-aldehyde 14 (8 $\mathrm{mg}, 82 \%)$ as a white solid: $\mathrm{mp} 121$ $123{ }^{\circ} \mathrm{C}$ (hexanes : EtOAc, $1: 2$ ); $R_{f} 0.35$ (hexanes : EtOAc: $\left.\mathrm{MeOH}, 1: 1: 0.2\right) ;[\alpha]_{\mathrm{D}}^{22}-73.1\left(\mathrm{c} 1.03, \mathrm{CHCl}_{3}\right)$; IR (film) 2924, 2849, $1692 \mathrm{~cm}^{-1}$; ${ }^{1} \mathrm{H}$ NMR (300 MHz, CDCl $) \delta 9.33$ (d, J $\left.6.1 \mathrm{~Hz}, 4 \mathrm{H}, \mathrm{CHO}\right), 1.87-1.77(\mathrm{~m}, 4 \mathrm{H}$, cyclopropane), $1.33-1.10\left(\mathrm{~m}, 12 \mathrm{H}\right.$, cyclopropane), 1.20 (s, $12 \mathrm{H}$, adamantane methylene); ${ }^{13} \mathrm{C} \mathrm{NMR}(75 \mathrm{MHz}$, $\left.\mathrm{CDCl}_{3}\right) \delta 200.0,46.9,36.5,34.9,29.6,9.9$; the product did not exhibit a molecular ion in the MS. Anal. calc for $\mathrm{C}_{26} \mathrm{H}_{32} \mathrm{O}_{4}$ : C, 76.44; $\mathrm{H}, 7.90$. Found: $\mathrm{C}, 76.37 ; \mathrm{H}, 8.03$.

\section{1,3,5,7-Tetra-((1R,2S)-2-( $N$-4-toluenesulfonylamino-iminomethyl)-1-cyclopropyl)adamantane (36).}

p-Toluenesulfonylhydrazine hydrochloride $(42 \mathrm{mg}, 0.225 \mathrm{mmol}$ ) was added with stirring to tetra-aldehyde 14 (23 $\mathrm{mg}, 0.056 \mathrm{mmol}$ ) in $\mathrm{MeOH}(3 \mathrm{~mL}$ ) at room temperature. After $4.5 \mathrm{~h}$, evaporation in vacuo and chromatography of the residue (hexanes: EtOAc: MeOH, 1:1:0.02) gave tetra-tosylhydrazone 36 (50 mg, $82 \%$ ) as a white solid: $\mathrm{mp} 149-151{ }^{\circ} \mathrm{C}$ (hexanes : EtOAc, $1: 2$ ); $R_{f} 0.31$ (hexanes : EtOAc : $\mathrm{MeOH}, 1: 1: 0.2$ ); $[\alpha]_{D}{ }^{22}-154.7$ (c 1.02, $\mathrm{CHCl}_{3}$ ); IR (film) 3204, 2923, 2852, 1334, $1164 \mathrm{~cm}^{-1} ;{ }^{1} \mathrm{H}$ NMR (300 MHz, $\left.\mathrm{CDCl}_{3}\right) \delta 9.23-8.38$ $(\mathrm{m}, 4 \mathrm{H}, \mathrm{CH}=\mathrm{NNHTs}), 7.97-7.89(\mathrm{~m}, 8 \mathrm{H}, \mathrm{ArH}), 7.35-7.28(\mathrm{~m}, 8 \mathrm{H}, \mathrm{ArH}), 7.08-6.98(\mathrm{~m}, 2 \mathrm{H}, \mathrm{CH}=\mathrm{NNHTs}), 6.61-6.48$ (m, 2H, CH=NNHTs), 2.40 (s, 12H, ArCH $\left.\mathrm{H}_{3}\right), 1.59$ (br s, 4H, cyclopropane methine), 1.27 (s, 8H, cyclopropane methylene), 1.12-0.75 (m, 16H, cyclopropane methine and adamantane methylene); the product did not exhibit a molecular ion in the MS.

1-Adamantyl)acetaldehyde 38. DMSO (1.60 mL, $22.5 \mathrm{mmol})$ in $\mathrm{CH}_{2} \mathrm{Cl}_{2}(2 \mathrm{~mL})$ was added with vigorous stirring over $2 \mathrm{~min}$ to $(\mathrm{COCl})_{2}(0.263 \mathrm{~mL}, 3.06 \mathrm{mmol})$ in $\mathrm{CH}_{2} \mathrm{Cl}_{2}(7 \mathrm{~mL})$ at $-78{ }^{\circ} \mathrm{C}$. After $15 \mathrm{~min}, 1$-adamantaneethanol (37) (500 mg, $2.78 \mathrm{mmol}$ ) in $\mathrm{CH}_{2} \mathrm{Cl}_{2}(4 \mathrm{~mL})$ was added slowly with stirring at $-78{ }^{\circ} \mathrm{C}$ and, after a further $30 \mathrm{~min}$, $\mathrm{Et}_{3} \mathrm{~N}(1.95 \mathrm{~mL})$ was added dropwise, and the mixture was allowed to warm up to room temperature over $1 \mathrm{~h}$. $\mathrm{H}_{2} \mathrm{O}(15 \mathrm{~mL})$ was added and the two phases were separated and the organic layer was washed with $5 \%$ aqueous $\mathrm{HCl}(10 \mathrm{~mL}), \mathrm{H}_{2} \mathrm{O}(10 \mathrm{~mL}), 5 \%$ aqueous $\mathrm{NaHCO}_{3}(10 \mathrm{~mL})$ and brine $(10 \mathrm{~mL})$, dried $\left(\mathrm{MgSO}_{4}\right)$, and concentrated in vacuo. The residue was chromatographed (hexanes: EtOAc, $30: 1$ ) to afford the aldehyde 38 (444 mg, 90\%) as a colorless oil: $R_{f} 0.44$ (hexanes : EtOAc, $10: 1$ ); IR (film) 2902, 2848, $1720 \mathrm{~cm}^{-1} ;{ }^{1} \mathrm{H} \mathrm{NMR}(400$ $\left.\mathrm{MHz}_{2} \mathrm{CDCl}_{3}\right) \delta 9.87(\mathrm{t}, J 3.4 \mathrm{~Hz}, 1 \mathrm{H}, \mathrm{CHO}), 2.12$ (d, J $\left.3.4 \mathrm{~Hz}, 2 \mathrm{H}, \mathrm{CH}_{2} \mathrm{CHO}\right), 1.98$ (s, 3H, adamantane methine), 1.74-1.64 (m, 12H, adamantane methylene); ${ }^{13} \mathrm{C} \mathrm{NMR}\left(100 \mathrm{MHz}, \mathrm{CDCl}_{3}\right) \delta 203.8,57.2,42.7,36.6,33.3,28.4$; MS (EI) $m / z 178\left(\mathrm{M}^{+}\right.$); HRMS (EI) $\mathrm{m} / z$ calc for $\mathrm{C}_{12} \mathrm{H}_{18} \mathrm{O}$ 178.1358, found: 178.1353. All spectroscopic data were consistent with the literature values. ${ }^{37}$

Ethyl 4-(Adamantan-1-yl)-3-oxobutanoate (39a). ${ }^{47}$ Aldehyde 38 (89 mg, $0.50 \mathrm{mmol}$ ) in $\mathrm{CH}_{2} \mathrm{Cl}_{2}(2 \mathrm{~mL})$ was added with stirring to anhydrous $\mathrm{SnCl}_{2}(9.5 \mathrm{mg}, 0.05 \mathrm{mmol})$ and ethyl diazoacetate $(58 \mu \mathrm{L}, 0.55 \mathrm{mmol})$ in $\mathrm{CH}_{2} \mathrm{Cl}_{2}(2 \mathrm{~mL})$ at room temperature. After $1 \mathrm{~h}$, the mixture was washed with brine $(5 \mathrm{~mL})$ and extracted with $\mathrm{CH}_{2} \mathrm{Cl}_{2}(3 \times 10 \mathrm{~mL})$. The organic extracts were dried $\left(\mathrm{MgSO}_{4}\right)$, concentrated in vacuo and the residue was chromatographed (hexanes : EtOAc, $40: 1$ ) to afford the $\beta$-keto ester 39a (106 mg, 80\%) (ca. $4: 1$ keto form and enol form) as a colorless oil: $R_{f} 0.44$ (hexanes : EtOAc, $10: 1$ ); IR (film) 2903, 2848, 1744, 1715, 1630 cm-1; ${ }^{1} \mathrm{H}$ NMR (400 MHz, CDCl 3 ): (keto form) $\delta 4.19$ (q, J $7.1 \mathrm{~Hz}, 2 \mathrm{H}, \mathrm{CO}_{2} \mathrm{CH}_{2} \mathrm{CH}_{3}$ ), 3.41 (s, $2 \mathrm{H}, \mathrm{CH}_{2} \mathrm{CO}_{2} \mathrm{Et}$ ), 2.28 (s, $2 \mathrm{H}$, $\left.\mathrm{CH}_{2} \mathrm{COCH}_{2} \mathrm{CO}_{2} \mathrm{Et}\right), 1.96(\mathrm{~s}, 3 \mathrm{H}$, adamantane methine), 1.65-1.64 (m, 12H, adamantane methylene), $1.29(\mathrm{t}, \mathrm{J} 7.1$ $\mathrm{Hz}, 3 \mathrm{H}, \mathrm{CO}_{2} \mathrm{CH}_{2} \mathrm{CH}_{3}$ ); (enol form) $\delta 12.10(\mathrm{~s}, 1 \mathrm{H}, \mathrm{HOC}=\mathrm{CH}), 4.90(\mathrm{~s}, 1 \mathrm{H}, \mathrm{HOC}=\mathrm{CH}), 4.19(\mathrm{q}, J 7.2 \mathrm{~Hz}, 2 \mathrm{H}$, $\left.\mathrm{CO}_{2} \mathrm{CH}_{2} \mathrm{CH}_{3}\right), 1.93\left(\mathrm{~s}, 2 \mathrm{H}, \mathrm{CH}_{2} \mathrm{C}(\mathrm{OH})=\mathrm{CH}\right), 1.72(\mathrm{~s}, 3 \mathrm{H}$, adamantane methine), 1.69-1.59 (m, 12H, adamantane methylene), 1.31 (t, J $7.2 \mathrm{~Hz}, 3 \mathrm{H}, \mathrm{CO}_{2} \mathrm{CH}_{2} \mathrm{CH}_{3}$ ); ${ }^{13} \mathrm{C} \mathrm{NMR} \mathrm{(100} \mathrm{MHz,} \mathrm{CDCl}$ ): (keto form) $\delta 202.4,167.2,61.3$, 56.0, 51.9, 42.3, 36.8, 33.7, 28.5, 14.2; (enol form) $\delta 176.8,172.6,91.3,59.9,50.0,42.6,36.7,33.4,28.7,14.3$; MS (EI) $m / z 264$ (M+.); HRMS (EI) $m / z$ calc for $\mathrm{C}_{16} \mathrm{H}_{24} \mathrm{O}_{3} 264.1725$, found: 264.1717. 
Ethyl 4-(Adamantan-1-yl)-2-diazo-3-oxobutanoate (41a). $\mathrm{Et}_{3} \mathrm{~N}(0.126 \mathrm{~mL}, 0.898 \mathrm{mmol})$ was added dropwise with stirring to $\beta$-keto ester 39a (79 $\mathrm{mg}, 0.299 \mathrm{mmol}$ ) and 4-acetamidobenzenesulfonyl azide (40) (79 mg, $0.329 \mathrm{mmol})$ in dry $\mathrm{MeCN}(4 \mathrm{~mL})$ at $0{ }^{\circ} \mathrm{C}$. After stirring for $3 \mathrm{~h}$ at room temperature, the reaction mixture was concentrated in vacuo and the resultant solid was triturated with $\mathrm{Et}_{2} \mathrm{O}$ and hexanes (1:1) $(60 \mathrm{~mL})$. The filtrate was concentrated in vacuo and the residue was chromatographed (hexanes : EtOAc, $30: 1$ ) to afford $\alpha$-diazoB-keto ester 41a (86 mg, 99\%) as a viscous oil: $R_{f} 0.46$ (hexanes : EtOAc, 10 : 1); IR (film) 2903, 2849, 2131, 1719, $1650 \mathrm{~cm}^{-1}$; ${ }^{1} \mathrm{H}$ NMR (400 MHz, CDCl 3 ) $\delta 4.29$ (q, J $7.2 \mathrm{~Hz}, 2 \mathrm{H}, \mathrm{CO}_{2} \mathrm{CH}_{2} \mathrm{CH}_{3}$ ), $2.71\left(\mathrm{~s}, 2 \mathrm{H}, \mathrm{CH}_{2} \mathrm{COC}_{2} \mathrm{~N}_{2}\right), 1.95$ (s, $3 \mathrm{H}$, adamantane methine), 1.67-1.66 (m, $12 \mathrm{H}$, adamantane methylene), $1.34\left(\mathrm{t}, \mathrm{J} 7.2 \mathrm{~Hz}, 3 \mathrm{H}, \mathrm{CO}_{2} \mathrm{CH}_{2} \mathrm{CH}_{3}\right)$; ${ }^{13} \mathrm{C}$ NMR $\left(100 \mathrm{MHz}, \mathrm{CDCl}_{3}\right) \delta$ 191.9, 161.5, 77.3, 61.3, 51.5, 42.4, 36.8, 34.7, 28.7, 14.4; MS (EI) $\mathrm{m} / z 290$ (M+.); HRMS (EI) $m / z$ calc for $\mathrm{C}_{16} \mathrm{H}_{22} \mathrm{~N}_{2} \mathrm{O}_{3} 290.1630$, found: 290.1626 .

tert-Butyl 4-(Adamantan-1-yl)-3-oxobutanoate (39b). Aldehyde 38 (390 mg, $2.19 \mathrm{mmol}$ ) in $\mathrm{CH}_{2} \mathrm{Cl}_{2}(6 \mathrm{~mL})$ was added with stirring to anhydrous $\mathrm{SnCl}_{2}(42 \mathrm{mg}, 0.22 \mathrm{mmol}$ ) and tert-butyl diazoacetate $(0.333 \mathrm{~mL}, 2.41 \mathrm{mmol})$ in $\mathrm{CH}_{2} \mathrm{Cl}_{2}(6 \mathrm{~mL})$ at room temperature. After $1.5 \mathrm{~h}$, the mixture was washed with brine $(15 \mathrm{~mL})$ and extracted with $\mathrm{CH}_{2} \mathrm{Cl}_{2}(3 \times 20 \mathrm{~mL})$. The organic extracts were dried $\left(\mathrm{MgSO}_{4}\right)$, concentrated in vacuo and the residue was chromatographed (hexanes : EtOAc, $40: 1$ ) to afford the $\beta$-keto ester 39b (390 mg, 61\%) (ca. $6: 4$ keto form and enol form) as a colorless oil: $R_{f} 0.41$ (hexanes : EtOAc, $10: 1$ ); IR (film) 2902, 2848, 1739, 1714, $1637 \mathrm{~cm}^{-1}$; ${ }_{1}^{1} \mathrm{H} \mathrm{NMR}$ (400 MHz, CDCl 3 ): (keto form) $\delta 3.24\left(\mathrm{~s}, 2 \mathrm{H}, \mathrm{CH}_{2} \mathrm{CO}_{2} \mathrm{C}\left(\mathrm{CH}_{3}\right)_{3}\right), 2.19\left(\mathrm{~s}, 2 \mathrm{H}, \mathrm{CH}_{2} \mathrm{COCH}_{2} \mathrm{CO}_{2} \mathrm{C}\left(\mathrm{CH}_{3}\right)_{3}\right), 1.89$ (s, $3 \mathrm{H}$, adamantane methine), 1.64-1.52 (m, $12 \mathrm{H}$, adamantane methylene), $1.40\left(\mathrm{~s}, 9 \mathrm{H}, \mathrm{CH}_{2} \mathrm{CO}_{2} \mathrm{C}\left(\mathrm{CH}_{3}\right)_{3}\right) ;(\mathrm{enol}$ form) $\delta 12.15(\mathrm{~s}, 1 \mathrm{H}, \mathrm{HOC}=\mathrm{CH}), 4.73(\mathrm{~s}, 1 \mathrm{H}, \mathrm{HOC}=\mathrm{CH}), 1.89(\mathrm{~s}, 3 \mathrm{H}$, adamantane methine), $1.83(\mathrm{~s}, 2 \mathrm{H}$, $\left.\mathrm{CH}_{2} \mathrm{C}(\mathrm{OH})=\mathrm{CH}\right), 1.61-1.52\left(\mathrm{~m}, 12 \mathrm{H}\right.$, adamantane methylene), $1.43\left(\mathrm{t}, 9 \mathrm{H}, \mathrm{CH}_{2} \mathrm{CO}_{2} \mathrm{C}\left(\mathrm{CH}_{3}\right)_{3}\right) ;{ }^{13} \mathrm{C} \mathrm{NMR}(100 \mathrm{MHz}$, $\mathrm{CDCl}_{3}$ ): (keto form) $\delta 202.9,166.5,81.7,55.9,53.1,42.3,36.7,33.6,28.5,28.0$; (enol form) $\delta 176.1,172.6$, 92.7, 80.6, 50.0, 42.6, 36.8, 33.3, 28.7, 28.3; MS (EI) $\mathrm{m} / z 292\left(\mathrm{M}^{+}\right.$) ; HRMS (EI) $\mathrm{m} / z$ calc for $\mathrm{C}_{18} \mathrm{H}_{28} \mathrm{O}_{3} 292.2038$, found: 292.2034; Anal. Calc for $\mathrm{C}_{18} \mathrm{H}_{28} \mathrm{O}_{3}$ : C, 73.93; $\mathrm{H}, 9.65$. Found: $\mathrm{C}, 74.01 ; \mathrm{H}, 9.58$.

tert-Butyl 4-(Adamantan-1-yl)-2-diazo-3-oxobutanoate (41b). $\mathrm{Et}_{3} \mathrm{~N}$ (0.162 $\left.\mathrm{mL}, 1.15 \mathrm{mmol}\right)$ was added dropwise with stirring to $\beta$-keto ester $39 \mathrm{~b}(112 \mathrm{mg}, 0.384 \mathrm{mmol})$ and 4-acetamidobenzenesulfonyl azide (40) (101 mg, $0.422 \mathrm{mmol}$ ) in dry $\mathrm{MeCN}(5 \mathrm{~mL})$ at $0{ }^{\circ} \mathrm{C}$ and the mixture was allowed to warm up to room temperature. After $4 \mathrm{~h}$, the reaction mixture was concentrated in vacuo and the resultant solid was triturated with $\mathrm{Et}_{2} \mathrm{O}$ and hexanes (1:1), the filtrate was concentrated in vacuo and the residue chromatographed (hexanes : EtOAc, $40: 1$ ) to afford $\alpha$-diazo- $\beta$-keto ester $\mathbf{4 1 b}(109 \mathrm{mg}, 90 \%)$ as a viscous oil: $R_{f} 0.41$ (hexanes : EtOAc, 10 : 1); IR (film) 2904, 2848, 2129, 1712, 1689, $1648 \mathrm{~cm}^{-1} ;{ }^{1} \mathrm{H} \mathrm{NMR}\left(400 \mathrm{MHz}, \mathrm{CDCl}_{3}\right) \delta 2.66(\mathrm{~s}, 2 \mathrm{H}$, $\left.\mathrm{CH}_{2} \mathrm{COC}\left(\mathrm{N}_{2}\right)\right), 1.93\left(\mathrm{~s}, 3 \mathrm{H}\right.$, adamantane methine), $1.66\left(\mathrm{~m}, 12 \mathrm{H}\right.$, adamantane methylene), $1.52\left(\mathrm{~s}, 9 \mathrm{H}, \mathrm{C}(\mathrm{CH})_{3}\right)$; ${ }^{13} \mathrm{C}$ NMR $\left(100 \mathrm{MHz}, \mathrm{CDCl}_{3}\right) \delta$ 192.0, 160.6, 82.9, 78.2, 51.3, 42.3, 36.7, 34.5, 28.7, 28.2; MS (EI) $\mathrm{m} / \mathrm{z} 318\left(\mathrm{M}^{+.}\right)$; HRMS (EI) $m / z$ calc for $\mathrm{C}_{18} \mathrm{H}_{26} \mathrm{~N}_{2} \mathrm{O}_{3} 318.1943$, found: 318.1942; Anal. Calc for $\mathrm{C}_{18} \mathrm{H}_{26} \mathrm{~N}_{2} \mathrm{O}_{3}$ : C, 67.90; $\mathrm{H}, 8.23 ; \mathrm{N}$, 8.80. Found: $\mathrm{C}, 68.01 ; \mathrm{H}, 8.27 ; \mathrm{N}, 8.74$.

1,3-Di-(2-hydroxyethyl)adamantane (43). ${ }^{40} \mathrm{LiAlH}_{4}(754 \mathrm{mg}, 19.8 \mathrm{mmol}$ ) was added portionwise with stirring to di-acid $42(1.0 \mathrm{~g}, 3.97 \mathrm{mmol})$ in THF $(30 \mathrm{~mL})$ at $0{ }^{\circ} \mathrm{C}$ and the mixture was allowed to warm up to room temperature. After $18 \mathrm{~h}$, saturated aqueous $\mathrm{Na}_{2} \mathrm{SO}_{4}(1.50 \mathrm{~mL})$ was added carefully to quench the reaction at 0 ${ }^{\circ} \mathrm{C}$ and the mixture was stirred for an additional $30 \mathrm{~min}$, when THF (40 mL) and silica gel $(2.0 \mathrm{~g})$ were added. The mixture was filtered through a short pad of Celite, eluting with THF (60 mL). Rotary evaporation of the filtrate and chromatography of the residue (hexanes : EtOAc : MeOH, $1: 1: 0.02$ to $1: 1: 0.0 .5$ ) gave diol 43 
(658 mg, 74\%) as colorless needles: mp 112 - $113{ }^{\circ} \mathrm{C}\left(\mathrm{MeOH}: \mathrm{CH}_{2} \mathrm{Cl}_{2}, 1: 2\right.$ ) (lit. ${ }^{40} \mathrm{mp} 113-115^{\circ} \mathrm{C}$ ); $R_{f} 0.39$ (hexanes : EtOAc : MeOH, $1: 1$ : 0.02); IR (film) 3389 (br), 2899, 2359, $1644 \mathrm{~cm}^{-1} ;{ }^{1} \mathrm{H}$ NMR (400 MHz, DMSO-d $\left.d_{6}\right)$ $\delta 4.19\left(\mathrm{t}, J 5.0 \mathrm{~Hz}, 2 \mathrm{H}, \mathrm{CH}_{2} \mathrm{OH}\right), 3.45\left(\mathrm{td}, J \mathrm{~J} .6,5.0 \mathrm{~Hz}, 4 \mathrm{H}, \mathrm{CH}_{2} \mathrm{OH}\right), 1.94(\mathrm{~m}, 2 \mathrm{H}$, adamantane methine), 1.55 (s, $2 \mathrm{H}$, adamantane methylene), $1.46-1.36\left(\mathrm{~m}, 8 \mathrm{H}\right.$, adamantane methylene and $\left.\mathrm{CH}_{2} \mathrm{CH}_{2} \mathrm{OH}\right), 1.28-1.23(\mathrm{~m}, 6 \mathrm{H}$, adamantane methylene); ${ }^{13} \mathrm{C}$ NMR $\left(100 \mathrm{MHz}\right.$, DMSO- $\left.d_{6}\right) \delta 56.4,47.9,46.8,41.9,36.3,32.2,28.6 ; \mathrm{MS}$ (EI) $\mathrm{m} / \mathrm{z}$ $224\left(\mathrm{M}^{+}\right.$); HRMS (EI) $\mathrm{m} / \mathrm{z}$ calc for $\mathrm{C}_{14} \mathrm{H}_{24} \mathrm{O}_{2} 224.1776$, found: 224.1773 . All spectroscopic data were consistent with the literature values. ${ }^{40}$

2,2'-(Adamantane-1,3-diyl)diacetaldehyde (44). DMSO (0.47 mL, $6.61 \mathrm{mmol}$ ) in $\mathrm{CH}_{2} \mathrm{Cl}_{2}$ (2 $\left.\mathrm{mL}\right)$ was added dropwise over 2 min with vigorous stirring to $(\mathrm{COCl})_{2}(0.284 \mathrm{~mL}, 3.30 \mathrm{mmol})$ in $\mathrm{CH}_{2} \mathrm{Cl}_{2}(2 \mathrm{~mL})$ at $-78^{\circ} \mathrm{C}$. After $10 \mathrm{~min}$, diol $43(500 \mathrm{mg}, 2.78 \mathrm{mmol})$ in $\mathrm{CH}_{2} \mathrm{Cl}_{2}(4 \mathrm{~mL})$ and anhydrous DMSO $(2 \mathrm{~mL})$ was added slowly with stirring at $-78{ }^{\circ} \mathrm{C}$. After $1 \mathrm{~h}, \mathrm{Et}_{3} \mathrm{~N}(2.30 \mathrm{~mL})$ was added dropwise with stirring, and the mixture was allowed to warm up to room temperature for $1 \mathrm{~h}$. $\mathrm{H}_{2} \mathrm{O}(15 \mathrm{~mL})$ was added, the two phases were separated and the organic layer was washed with $5 \%$ aqueous $\mathrm{HCl}(10 \mathrm{~mL}), \mathrm{H}_{2} \mathrm{O}(10 \mathrm{~mL}), 5 \%$ aqueous $\mathrm{NaHCO}_{3}(10 \mathrm{~mL})$ and brine $(10 \mathrm{~mL})$, dried $\left(\mathrm{MgSO}_{4}\right)$ and concentrated in vacuo. The residue was chromatographed (hexanes : EtOAc, $8: 1$ ) to afford the di-aldehyde $44(150 \mathrm{mg}, 83 \%)$ as a colorless oil: $R_{f} 0.52$ (hexanes : EtOAc, $\left.2: 1\right)$; IR (film) 2901, 2848, $1719 \mathrm{~cm}^{-1} ;{ }^{1} \mathrm{H}$ NMR (400 MHz, CDCl 3$) \delta 9.86\left(\mathrm{t}, J 3.1 \mathrm{~Hz}, 2 \mathrm{H}, \mathrm{CH}_{2} \mathrm{CHO}\right), 2.12\left(\mathrm{~d}, J 3.1 \mathrm{~Hz}, 4 \mathrm{H}, \mathrm{CH} \mathrm{CHO}_{2}\right.$ ), $2.10\left(\mathrm{~m}, 2 \mathrm{H}\right.$, adamantane methine), 1.69-1.58 (m, 12H, adamantane methylene); ${ }^{13} \mathrm{C} \mathrm{NMR}\left(100 \mathrm{MHz}^{\mathrm{CDCl}} \mathrm{CD}_{3}\right.$ $\delta$ 202.9, 56.6, 47.7, 41.7, 35.7, 33.9, 28.6; MS (EI) $\mathrm{m} / z 220\left(\mathrm{M}^{+}\right.$); HRMS (EI) $\mathrm{m} / z$ calc for $\mathrm{C}_{14} \mathrm{H}_{20} \mathrm{O}_{2} 220.1463$, found: 220.1462 .

Di-tert-butyl 4,4'-(Adamantane-1,3-diyl)bis(3-oxobutanoate) (45). Di-aldehyde 44 (148 mg, $0.673 \mathrm{mmol}$ ) in $\mathrm{CH}_{2} \mathrm{Cl}_{2}(2 \mathrm{~mL})$ was added with stirring to anhydrous $\mathrm{SnCl}_{2}(38 \mathrm{mg}, 0.202 \mathrm{mmol}$ ) and tert-butyl diazoacetate $(0.24 \mathrm{~mL}, 1.68 \mathrm{mmol})$ in $\mathrm{CH}_{2} \mathrm{Cl}_{2}(4 \mathrm{~mL})$ at room temperature. After $1.5 \mathrm{~h}$, the mixture was washed with brine (5 $\mathrm{mL}$ ) and extracted with $\mathrm{CH}_{2} \mathrm{Cl}_{2}(3 \times 10 \mathrm{~mL})$, the organic extracts were dried $\left(\mathrm{MgSO}_{4}\right)$ and concentrated in vacuo. The resultant residue was chromatographed (hexanes : EtOAc, $12: 1)$ to afford the di- $\beta$-keto ester 45 (225 mg, 75\%) (ca. $2.5: 1$ keto : enol forms) as a viscous colorless oil: $R_{f} 0.51$ (hexanes: EtOAc, $4: 1$ ); IR (film) 2903, 1739, 1713, $1638 \mathrm{~cm}^{-1}$; ${ }^{1} \mathrm{H}$ NMR $\left(400 \mathrm{MHz}, \mathrm{CDCl}_{3}\right.$ ): (keto form) $\delta 3.30$ (s, $\left.4 \mathrm{H}, \mathrm{CH}_{2} \mathrm{CO}_{2} \mathrm{C}\left(\mathrm{CH}_{3}\right)_{3}\right), 2.29(\mathrm{~s}, 4 \mathrm{H}$, $\left.\mathrm{CH}_{2} \mathrm{COCH}_{2} \mathrm{CO}_{2} \mathrm{C}\left(\mathrm{CH}_{3}\right)_{3}\right), 2.05$ (s, 2H, adamantane methine), 1.64-1.54 (m, 12H, adamantane methylene), 1.47 (s, $\left.18 \mathrm{H}, \mathrm{CH}_{2} \mathrm{CO}_{2} \mathrm{C}\left(\mathrm{CH}_{3}\right)_{3}\right)$; (enol form) $\delta 12.21(\mathrm{~s}, 2 \mathrm{H}, \mathrm{HOC}=\mathrm{CH}), 4.80(\mathrm{~s}, 2 \mathrm{H}, \mathrm{HOC}=\mathrm{CH}), 2.05$ (s, 2H, adamantane methine), $1.92(\mathrm{~s}, 4 \mathrm{H}, \mathrm{CH} 2 \mathrm{C}(\mathrm{OH})=\mathrm{CH}), 1.64-1.54\left(\mathrm{~m}, 12 \mathrm{H}\right.$, adamantane methylene), $1.50\left(\mathrm{~s}, 9 \mathrm{H}, \mathrm{CH}_{2} \mathrm{CO}_{2} \mathrm{C}\left(\mathrm{CH}_{3}\right)_{3}\right)$; ${ }^{13} \mathrm{C} \mathrm{NMR}\left(100 \mathrm{MHz}, \mathrm{CDCl}_{3}\right.$ ): (keto form) $\delta$ 202.6, 166.4, 81.8, 55.3, 53.0, 46.9, 41.3, 34.1, 28.7, 28.0; (enol form) $\delta$ 175.7, 172.6, 92.9, 80.7, 49.5, 47.5, 41.7, 35.8, 28.9, 28.4; MS (ES) $m / z 471$ (M + Na+); HRMS (ES) $m / z$ calc for $\mathrm{C}_{26} \mathrm{H}_{40} \mathrm{O}_{6} \mathrm{Na}$ 471.2723, found: 471.2715; Anal. Calc for $\mathrm{C}_{26} \mathrm{H}_{40} \mathrm{O}_{6}$ : C, 69.61; H, 8.99. Found: $\mathrm{C}, 69.56 ; \mathrm{H}, 9.04$.

Di-tert-butyl 4,4'-(Adamantane-1,3-diyl)bis(2-diazo-3-oxobutanoate (46). Et $\mathrm{t}_{3} \mathrm{~N}$ (0.395 mL, $\left.2.81 \mathrm{mmol}\right)$ was added dropwise with stirring to di- $\beta$-keto ester $45(210 \mathrm{mg}, 0.469 \mathrm{mmol})$ and 4-acetamidobenzenesulfonyl azide (40) $(248 \mathrm{mg}, 1.03 \mathrm{mmol})$ in dry $\mathrm{MeCN}(12 \mathrm{~mL})$ at $0{ }^{\circ} \mathrm{C}$ and the mixture was allowed to warm up to room temperature. After $4 \mathrm{~h}$, the mixture was concentrated in vacuo and the resultant solid was triturated with $\mathrm{Et}_{2} \mathrm{O}$ and hexanes $(1: 1)(80 \mathrm{~mL})$. The mixture was filtered, the filtrate was concentrated in vacuo and the residue chromatographed (hexanes: EtOAc, $20: 1)$ to afford di- $\alpha$-diazo- $\beta$-keto ester 46 (184 mg, 79\%) as a viscous colorless oil: $R_{f} 0.60$ (hexanes : EtOAc, $\left.4: 1\right)$; IR (film) 2904, 2129, 1712, $1648 \mathrm{~cm}^{-1} ;{ }^{1} \mathrm{H} \mathrm{NMR}(400 \mathrm{MHz}, \mathrm{CDCl} 3) \delta$ $2.65\left(\mathrm{~s}, 4 \mathrm{H}, \mathrm{CH}_{2} \mathrm{COC}\left(\mathrm{N}_{2}\right)\right), 1.97(\mathrm{~m}, 2 \mathrm{H}$, adamantane methine), 1.61-1.54 (m, 12H, adamantane methylene), 
1.49 (s, 18H, C(CH3) $)$; ${ }^{13} \mathrm{C}$ NMR $\left(100 \mathrm{MHz}, \mathrm{CDCl}_{3}\right) \delta$ 191.8, 160.5, 83.0, 78.2, 51.0, 47.2, 41.4, 35.9, 35.1, 29.0, 28.3; MS (ES) $m / z 471\left(\mathrm{M}+\mathrm{Na}^{+}\right.$); $\mathrm{HRMS}$ (ES) $m / z$ calc for $\mathrm{C}_{26} \mathrm{H}_{40} \mathrm{O}_{6} \mathrm{Na} 471.2723$, found: 471.2715.

Ethyl 2-Oxodecahydro-3a,7:5,9-dimethanocyclopenta[8]annulene-1-carboxylate (47a). $\mathrm{Rh}_{2}(\mathrm{OAc})_{4}$ (1.8 mg, $4.1 \mu \mathrm{mol})$ was added with stirring to $\alpha$-diazo- $\beta$-keto ester $41 \mathrm{a}(60 \mathrm{mg}, 0.21 \mathrm{mmol})$ in $\mathrm{CH}_{2} \mathrm{Cl}_{2}(5 \mathrm{~mL})$ at room temperature. After $1.5 \mathrm{~h}$, the solvent was removed in vacuo and the residue was chromatographed (hexanes: EtOAc, $25: 1$ ) to afford $\beta$-keto ester 47a (49 $\mathrm{mg}, 90 \%$ ) as a viscous oil containing a single diastereoisomer: $R_{f} 0.27$ (hexanes : EtOAc, $10: 1$ ); IR (film) 2905, 2852, 1755, $1724 \mathrm{~cm}^{-1} ;{ }^{1} \mathrm{H} \mathrm{NMR}(400 \mathrm{MHz}$, $\mathrm{CDCl}_{3}$ ) $\delta 4.19$ (q, J $7.2 \mathrm{~Hz}, 2 \mathrm{H}, \mathrm{COCH}_{2} \mathrm{CH}_{3}$ ), 3.29 (d, J $12.9 \mathrm{~Hz}, 1 \mathrm{H}, \mathrm{CHCO}{ }_{2} \mathrm{Et}$ ), 2.52 (dd, J 12.9, $1.6 \mathrm{~Hz}, 1 \mathrm{H}$, $\left.\mathrm{COCH}\left(\mathrm{CO}_{2} \mathrm{Et}\right) \mathrm{CH}\right), 2.07\left(\mathrm{~s}, 2 \mathrm{H}, \mathrm{CH}_{2} \mathrm{COCHCO}_{2} \mathrm{Et}\right), 2.02-1.64(\mathrm{~m}, 11 \mathrm{H}$, adamantane methylene and methine), 1.49 (s, $2 \mathrm{H}$, adamantane methine), $1.27\left(\mathrm{t}, J 7.2 \mathrm{~Hz}, 3 \mathrm{H}, \mathrm{COCH}_{2} \mathrm{CH}_{3}\right) ;{ }^{13} \mathrm{C} \mathrm{NMR}\left(100 \mathrm{MHz}, \mathrm{CDCl}_{3}\right) \delta 211.1,169.7,61.3$, $55.8,53.2,51.2,43.0,38.3,37.9,37.0,35.8,29.8,29.1,28.5,27.9,14.2 ; \mathrm{MS}$ (EI) $\mathrm{m} / z 262\left(\mathrm{M}^{+}\right.$); HRMS (EI) $\mathrm{m} / z$ calc for $\mathrm{C}_{16} \mathrm{H}_{22} \mathrm{O}_{3} 262.1569$, found: 262.1566 .

tert-Butyl 2-Oxodecahydro-3a,7:5,9-dimethanocyclopenta[8]annulene-1-carboxylate (47b). $\mathrm{Rh}_{2}(\mathrm{OAc})_{4}(14.5$ $\mathrm{mg}, 0.033 \mathrm{mmol}$ ) was added with stirring to $\alpha$-diazo- $\beta$-keto ester $\mathbf{4 1 b}$ (208 mg, $0.654 \mathrm{mmol}$ ) in $\mathrm{CH}_{2} \mathrm{Cl}_{2}(10 \mathrm{~mL})$ at room temperature. After $1.5 \mathrm{~h}$, the solvent was removed in vacuo and the residue chromatographed (hexanes : EtOAc, $30: 1)$ to afford $\beta$-ketoester $47 \mathrm{~b}(173 \mathrm{mg}, 91 \%)$ as a colorless viscous oil: $R_{f} 0.34$ (hexanes : EtOAc, 10 : 1); IR (film) 2906, 2852, 1752, $1722 \mathrm{~cm}^{-1} ;{ }^{1} \mathrm{H} \mathrm{NMR}\left(400 \mathrm{MHz}, \mathrm{CDCl}_{3}\right) \delta 3.18(\mathrm{~d}, \mathrm{~J} 12.9 \mathrm{~Hz}, 1 \mathrm{H}$, $\left.\mathrm{COCHCO} 2 \mathrm{C}\left(\mathrm{CH}_{3}\right)_{3}\right), 2.46\left(\mathrm{~d}, J 12.8 \mathrm{~Hz}, 1 \mathrm{H}, \mathrm{COCH}\left(\mathrm{CO}_{2} \mathrm{C}\left(\mathrm{CH}_{3}\right)_{3}\right) \mathrm{CH}\right), 2.06-1.67(\mathrm{~m}, 13 \mathrm{H}$, adamantane methylene and methine), $2.03\left(\mathrm{~s}, 2 \mathrm{H}, \mathrm{CH}_{2} \mathrm{COCH}\right), 1.45\left(\mathrm{~s}, 9 \mathrm{H}, \mathrm{C}\left(\mathrm{CH}_{3}\right)_{3}\right) ;{ }^{13} \mathrm{C} \mathrm{NMR}\left(100 \mathrm{MHz}, \mathrm{CDCl}_{3}\right) \delta 211.4,168.9,81.5$, 56.7, 53.1, 51.2, 42.9, 38.3, 37.9, 37.0, 35.6, 29.7, 29.1, 28.5, 28.0, 27.8; MS (EI) $\mathrm{m} / z 290$ (M ${ }^{+}$); HRMS (EI) $\mathrm{m} / z$ calc for $\mathrm{C}_{18} \mathrm{H}_{26} \mathrm{O}_{3}$ 290.1882, found: 290.1881; Anal. Calc for $\mathrm{C}_{18} \mathrm{H}_{26} \mathrm{O}_{3}$ : C, 74.45; $\mathrm{H}, 9.02$. Found: $\mathrm{C}, 74.55 ; \mathrm{H}$, 8.99 .

2-Oxodecahydro-3a,7:5,9-dimethanocyclopenta[8]annulene-1-carboxylic Acid (48). $\mathrm{CF}_{3} \mathrm{CO}_{2} \mathrm{H}(0.3 \mathrm{~mL})$ was added with stirring to tert-butyl ester $47 \mathrm{~b}(20 \mathrm{mg}, 0.069 \mathrm{mmol})$ in $\mathrm{CH}_{2} \mathrm{Cl}_{2}(3 \mathrm{~mL})$ at room temperature. After 3 $\mathrm{h}$, volatile materials were removed in vacuo and the residue was dried under vacuum for $4 \mathrm{~h}$ to leave the $\beta$ -

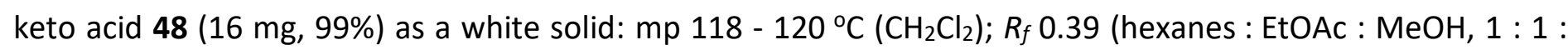
0.2); IR (film) 2906, 2852, 1752, $1702 \mathrm{~cm}^{-1} ;{ }^{1} \mathrm{H}$ NMR (400 MHz, CDCl $) \delta 8.54$ (br s, $1 \mathrm{H}, \mathrm{CO}_{2} \mathrm{H}$ ), 3.34 (d, J $13.0 \mathrm{~Hz}$, $\left.1 \mathrm{H}, \mathrm{CHCO}_{2} \mathrm{H}\right), 2.51\left(\mathrm{~d}, \mathrm{~J} 13.0 \mathrm{~Hz}, 1 \mathrm{H}, \mathrm{CH}\left(\mathrm{CO}_{2} \mathrm{H}\right) \mathrm{CH}\right), 2.17-2.07\left(\mathrm{~m}, 4 \mathrm{H}, \mathrm{CH}_{2} \mathrm{COCHCO}_{2} \mathrm{H}\right.$ and adamantane), 1.98$1.68\left(\mathrm{~m}, 9 \mathrm{H}\right.$, adamantane), 1.51 (s, $2 \mathrm{H}$, adamantane); ${ }^{13} \mathrm{C} \mathrm{NMR}\left(100 \mathrm{MHz}, \mathrm{CDCl}_{3}\right) \delta 211.4,174.3,55.3,53.1$, $51.1,42.9,38.2,37.9,37.0,35.8,29.6,29.1,28.5,27.8 ; \mathrm{MS}$ (EI) $\mathrm{m} / z 234\left(\mathrm{M}^{+}\right.$); HRMS (EI) $\mathrm{m} / z$ calc for $\mathrm{C}_{14} \mathrm{H}_{18} \mathrm{O}_{3}$ 234.1256, found: 234.1254 .

Octahydro-3a,7:5,9-dimethanocyclopenta[8]annulen-2(3H)-one (49). ${ }^{42}$ From $\beta$-keto-ethyl ester 47a. $\beta$ Ketoester 47a (46 mg, $0.176 \mathrm{mmol})$ and $\mathrm{NaCl}(20 \mathrm{mg}, 0.351 \mathrm{mmol})$ in DMSO $(6 \mathrm{~mL})$ and $\mathrm{H}_{2} \mathrm{O}(0.095 \mathrm{~mL}, 5.27$ $\mathrm{mmol}$ ) was stirred at $130-140{ }^{\circ} \mathrm{C}$ for $1.5 \mathrm{~h}$. The solution was cooled to room temperature, diluted with $\mathrm{Et}_{2} \mathrm{O}$ $(50 \mathrm{~mL})$ and washed with $\mathrm{H}_{2} \mathrm{O}(2 \times 15 \mathrm{~mL})$ and brine $(15 \mathrm{~mL})$. The organic extracts were dried $\left(\mathrm{MgSO}_{4}\right)$, concentrated in vacuo and the residue was chromatographed (hexanes: EtOAc, $25: 1$ ) to afford cyclopentanone 49 (30 mg, 90\%). From $\boldsymbol{\beta}$-keto-tert-butyl ester $47 \mathrm{~b}$. $\mathrm{CF}_{3} \mathrm{CO}_{2} \mathrm{H}(0.3 \mathrm{~mL})$ was added with stirring to tert-butyl ester $47 \mathrm{~b}(20 \mathrm{mg}, 0.069 \mathrm{mmol})$ in dry $\mathrm{PhCl}(5 \mathrm{~mL})$ at room temperature. The mixture was subsequently stirred at $120^{\circ} \mathrm{C}$ for $3 \mathrm{~h}$, after which the solvent was removed in vacuo. The crude material was dried under vacuum for $3 \mathrm{~h}$ to afford the cyclopentanone $\mathbf{4 9}$ (13 mg, 100\%). From $\beta$-keto-acid 48. $\beta$-Keto-acid 
48 (18 $\mathrm{mg}, 0.077 \mathrm{mmol})$ in 1,4-dioxane $(5 \mathrm{~mL})$ was heated under reflux for $3 \mathrm{~h}$, and the solvent was removed in vacuo. The residue was chromatographed (hexanes : EtOAc, $20: 1$ ) to afford the cyclopentanone 49 (12 mg, 82\%). The cyclopentanone 49 in these experiments was obtained as colorless crystals: $\mathrm{mp} 73-75{ }^{\circ} \mathrm{C}$ (EtOAc) (lit. ${ }^{48} \mathrm{mp} 74$ - $76{ }^{\circ} \mathrm{C}$ ); $R_{f} 0.22$ (hexanes : EtOAc, $15: 1$ ); IR (film) 2903, 2851, 1744, $1452 \mathrm{~cm}^{-1}$; ${ }^{1} \mathrm{H} \mathrm{NMR}(400 \mathrm{MHz}$, $\left.\mathrm{CDCl}_{3}\right) \delta 2.31\left(\mathrm{~m}, 1 \mathrm{H}, \mathrm{CH}_{2} \mathrm{C}=\mathrm{O}\right), 2.16\left(\mathrm{~m}, 2 \mathrm{H}, \mathrm{CH}_{2} \mathrm{C}=\mathrm{O}\right), 2.07\left(\mathrm{~m}, 1 \mathrm{H}, \mathrm{CH}_{2} \mathrm{C}=\mathrm{O}\right)$, 1.99-1.40 (m, 14H, adamantane methine and methylene); ${ }^{13} \mathrm{C} \mathrm{NMR}\left(75 \mathrm{MHz} \mathrm{CDCl}_{3}\right) \delta 219.1,53.8,47.3,43.1,39.6,38.6,37.5,37.1,36.9,29.5$, 29.2, 29.1, 27.9; MS (EI) $\mathrm{m} / z 190\left(\mathrm{M}^{+}\right)$; HRMS (EI) $\mathrm{m} / z$ calc for $\mathrm{C}_{13} \mathrm{H}_{18} \mathrm{O}\left(\mathrm{M}^{+}\right.$) 190.1358 , found: 190.1358. Anal. Calc for $\mathrm{C}_{13} \mathrm{H}_{18} \mathrm{O}$ : C, 82.06; $\mathrm{H}, 9.53$. Found: $\mathrm{C}, 82.14 ; \mathrm{H}, 9.63$.

\section{Di-tert-butyl 2,9-Dioxododecahydro-3a,7:5,10a-dimethanodicyclopenta[ $a, c]$ [8]annulene-1,8-dicarboxylate} (50). $\mathrm{Rh}_{2}(\mathrm{OAc})_{4}(17 \mathrm{mg}, 0.038 \mathrm{mmol})$ was added with stirring to di- $\alpha$-diazo- $\beta$-keto ester 46 (126 mg, 0.252 $\mathrm{mmol})$ in $\mathrm{CH}_{2} \mathrm{Cl}_{2}(6 \mathrm{~mL})$ at room temperature. After $1 \mathrm{~h}$, the solvent was removed in vacuo and the residue chromatographed (hexanes : EtOAc, $10: 1$ to $8: 1$ ) to give diester 50 (57 mg, 52\%) as a colorless viscous oil: $R_{f}$ 0.25 (hexanes : EtOAc, $4: 1$ ); IR (film) 2913, 2859, 1753, $1720 \mathrm{~cm}^{-1} ;{ }^{1} \mathrm{H}$ NMR (400 MHz, CDCl $) \delta 3.34-3.13(\mathrm{~m}$, $\left.2 \mathrm{H}, \mathrm{CHCO}_{2} \mathrm{C}\left(\mathrm{CH}_{3}\right)_{3}\right), 2.77-2.45\left(\mathrm{~m}, 2 \mathrm{H}, \mathrm{CHCHCO} 2 \mathrm{C}\left(\mathrm{CH}_{3}\right)_{3}\right), 2.31-1.61\left(\mathrm{~m}, 14 \mathrm{H}, \mathrm{CH}_{2} \mathrm{C}=\mathrm{O}\right.$ and adamantane), 1.48$1.45\left(\mathrm{~m}, 18 \mathrm{H}, \mathrm{CO}_{2} \mathrm{C}\left(\mathrm{CH}_{3}\right)_{3}\right)$; $\mathrm{MS}(\mathrm{EI}) \mathrm{m} / z 444\left(\mathrm{M}^{+}\right.$); HRMS (EI) $\mathrm{m} / z$ calc for $\mathrm{C}_{26} \mathrm{H}_{36} \mathrm{O}_{6} 444.2512$, found: 444.2514.

Octahydro-3a,7:5,10a-dimethanodicyclopenta[a,c][8]annulene-2,9(3H,10H)-dione (51). $\mathrm{CF}_{3} \mathrm{CO}_{2} \mathrm{H}(0.5 \mathrm{~mL})$ was added with stirring to di-tert-butyl ester $50(28 \mathrm{mg}, 0.063 \mathrm{mmol})$ in dry $\mathrm{PhCl}(5 \mathrm{~mL})$ at room temperature. The mixture was stirred at $115{ }^{\circ} \mathrm{C}$ for $3 \mathrm{~h}$, cooled and the solvent was removed in vacuo. The residue was chromatographed (hexanes : EtOAc, $4: 1$ ) to afford the di-ketone $\mathbf{5 1}(15 \mathrm{mg}, 97 \%)$ as a colorless oil: $R_{f} 0.24$ (hexanes : EtOAc, 2 : 1); IR (film) 2910, 2856, $1740 \mathrm{~cm}^{-1}$; ${ }^{1} \mathrm{H}$ NMR $\left(400 \mathrm{MHz}, \mathrm{CDCl}_{3}\right) \delta$ 2.4-2.1 (m, CH2 $\left.\mathrm{C}=0\right), 2.1-$ $1.3\left(\mathrm{~m}\right.$, adamantane methine and methylene); ${ }^{13} \mathrm{C} \mathrm{NMR}\left(75 \mathrm{MHz}, \mathrm{CDCl}_{3}\right) \delta 217,53.8,53.3,53.0,51.5,50.2$, 48.8, 47.4, 47.2, 47.144.8, 44.4, 43.1, 39.7, 39.6, 39.4, 39.2, 39.1, 39.0, 38.9, 38.2, 38.0, 37.9, 37.8, 37.2, 36.9, $36.8,36.535 .8,35.4,30.5,30.3,29.8,29.7,29.4,29.2$; MS (EI) $m / z 244\left(M^{++}\right)$; HRMS (EI) $m / z$ calc for $\mathrm{C}_{16} \mathrm{H}_{120} \mathrm{O}_{2}$ 244.1463, found: 244.1464; Anal. Calc for $\mathrm{C}_{16} \mathrm{H}_{20} \mathrm{O}_{2}$ : C, 78.65; $\mathrm{H}, 8.25$. Found: $\mathrm{C}, 78.55 ; \mathrm{H}, 8.37$.

1,3,5,7-Tetra-(2-methoxyethenyl)adamantane (52). NaN(SiMe $)_{2}$ in THF (1.0 M; $6.05 \mathrm{~mL}, 6.05$ mmol) was added with stirring to $\mathrm{Ph}_{3} \mathrm{PCH}_{2} \mathrm{OMeCl}(2.21 \mathrm{~g}, 6.45 \mathrm{mmol})$ in THF $(10 \mathrm{~mL})$ at $-78{ }^{\circ} \mathrm{C}$. After $1 \mathrm{~h}$, tetra-aldehyde 19 (200 mg, $0.806 \mathrm{mmol})$ in THF $(10 \mathrm{~mL})$ was added dropwise with stirring to the red solution and the mixture allowed to warm up to room temperature. After $16 \mathrm{~h}$, saturated aqueous $\mathrm{NH}_{4} \mathrm{Cl}(10 \mathrm{~mL})$ was added and the mixture was extracted with EtOAc $(3 \times 20 \mathrm{~mL})$. The combined organic layers were washed with brine $(20 \mathrm{~mL})$, dried $\left(\mathrm{MgSO}_{4}\right)$, concentrated in vacuo and the residue chromatographed (hexanes : EtOAc, $30: 1$ to $15: 1$ ) to give the tetra-enol ether 53 (ca. $1: 1\left(E\right.$ )-olefin : (Z)-olefin isomers) (230 mg, 80\%) as a colorless oil: $R_{f} 0.62$ (hexanes: EtOAc, $4: 1$ ); IR (film) 3019, 2930, 2901, 2849, 1656, $1449 \mathrm{~cm}^{-1}$; ${ }^{1} \mathrm{H}$ NMR (400 MHz, CDCl $) \delta 6.22$ (d, $J 12.9 \mathrm{~Hz}, 2 \mathrm{H},(E)$-isomer $\left.\mathrm{CH}=\mathrm{CHOCH}_{3}\right), 5.71-5.67\left(\mathrm{~m}, 2 \mathrm{H},(\mathrm{Z})\right.$-isomer $\left.\mathrm{CH}=\mathrm{CHOCH}_{3}\right), 4.72(\mathrm{~d}, J 12.9 \mathrm{~Hz}, 2 \mathrm{H},(E)$ isomer $\left.\mathrm{CH}=\mathrm{CHOCH}_{3}\right), 4.05\left(\mathrm{~d}, J 7.0 \mathrm{~Hz}, 2 \mathrm{H},(\mathrm{Z})\right.$-isomer $\left.\mathrm{CH}=\mathrm{CHOCH}_{3}\right), 3.53(\mathrm{~s}, 6 \mathrm{H},(\mathrm{Z})$-isomer $\mathrm{CH}=\mathrm{CHOCH}), 3.49$ $\left(\mathrm{s}, 6 \mathrm{H},(E)\right.$-isomer $\left.\mathrm{CH}=\mathrm{CHOCH}_{3}\right), 1.72-1.69(\mathrm{~m}, 6 \mathrm{H},(\mathrm{Z})$-isomer adamantane methylene), $1.52(\mathrm{~s}, 6 \mathrm{H},(E)$-isomer adamantane methylene); $\left.{ }^{13} \mathrm{C} \mathrm{NMR} \mathrm{(75} \mathrm{MHz,} \mathrm{CDCl}_{3}\right) \delta$ complex due to mixtures of geometric isomers 145.6144.7 (multiple peaks, $\mathrm{CH}=\mathrm{CH}(\mathrm{OMe}), 116.4-114.5$ (multiple peaks, $\mathrm{CH}=\mathrm{CH}(\mathrm{OMe}), 59.7,55.8,47.8-46.0$ (multiple peaks), 35.8, 34.4 (the peaks in the ${ }^{1} \mathrm{H}$ and ${ }^{13} \mathrm{C}$ NMR spectra for the $E$ - and $Z$ - $\mathrm{CH}=\mathrm{CHOMe}$ units were consistent with those in the spectra reported for the isolated $E$ - and Z-isomers of 1-(2-methoxyethenyl)-1methylcyclohexane ${ }^{49}$ ); the product did not exhibit a molecular ion in the MS. Anal. Calc for $\mathrm{C}_{22} \mathrm{H}_{32} \mathrm{O}_{4}: \mathrm{C}_{1} 73.30$; $H, 8.95$. Found: C, 73.34; H, 8.96. 
2,2',2",2"'-(Adamantane-1,3,5,7-tetrayl)tetraacetaldehyde (53). $\mathrm{CF}_{3} \mathrm{CO}_{2} \mathrm{H}$ (41 $\mathrm{mg}, 0.275 \mathrm{mmol}$ ) in solvent $\mathrm{CH}_{2} \mathrm{Cl}_{2}$, $i$ - $\mathrm{PrOH}$ and $\mathrm{H}_{2} \mathrm{O}(60: 20: 1 ;(5 \mathrm{~mL})$ was added dropwise with stirring to tetra-enol ether 52 (23 mg, $0.064 \mathrm{mmol}$ ) at room temperature. After $16 \mathrm{~h}$, saturated aqueous $\mathrm{NaHCO}_{3}(8 \mathrm{~mL})$ was added and the mixture was extracted with $\mathrm{CH}_{2} \mathrm{Cl}_{2}(3 \times 15 \mathrm{~mL})$. The combined organic layers were dried $\left(\mathrm{MgSO}_{4}\right)$, concentrated in vacuo and the residue chromatographed (hexanes: EtOAc:MeOH, $1: 1: 0.2$ ) to afford tetra-aldehyde 53 $(11.5 \mathrm{mg}, 60 \%)$ as colorless crystals: $\mathrm{mp} 124-126{ }^{\circ} \mathrm{C}$ (EtOAc); $R_{f} 0.24$ (hexanes : EtOAc : MeOH, $\left.1: 1: 0.2\right) ; \mathrm{IR}$ (film) 2923, 2850, $1713 \mathrm{~cm}^{-1}$; ${ }^{1} \mathrm{H}$ NMR $\left(400 \mathrm{MHz}, \mathrm{CDCl}_{3}\right) \delta 9.83(\mathrm{t}, J 2.6 \mathrm{~Hz}, 4 \mathrm{H}, \mathrm{CHO}), 2.28(\mathrm{~d}, J 2.6 \mathrm{~Hz}, 8 \mathrm{H}$, $\mathrm{CH}_{2} \mathrm{CHO}$ ), 1.56 (s, 12H, adamantane methylene); ${ }^{13} \mathrm{C} \mathrm{NMR} \mathrm{(100} \mathrm{MHz,} \mathrm{CDCl} 3$ ) $\delta$ 201.6, 55.4, 45.6, 34.8; MS (EI) $\mathrm{m} / z 304\left(\mathrm{M}^{+}\right)$; HRMS (EI) $\mathrm{m} / z$ calc for $\mathrm{C}_{18} \mathrm{H}_{24} \mathrm{O}_{4}\left(\mathrm{M}^{+}\right)$304.1675, found: 304.1683; Anal. Calc for $\mathrm{C}_{18} \mathrm{H}_{24} \mathrm{O}_{4}: \mathrm{C}_{\text {, }}$ 71.03; $\mathrm{H}, 7.95$. Found: $C, 70.98 ; \mathrm{H}, 7.93$.

2,2',2",2"'-(Adamantane-1,3,5,7-tetrayl)tetraacetic Acid (54a). ${ }^{13} \mathrm{NaClO}_{2}$ (308 $\mathrm{mg}, 2.74$ mmol) and $\mathrm{NaH}_{2} \mathrm{PO}_{4} \cdot \mathrm{H}_{2} \mathrm{O}(378 \mathrm{mg}, 2.74 \mathrm{mmol})$ in $\mathrm{H}_{2} \mathrm{O}(2.8 \mathrm{~mL})$ were added slowly with stirring to $t$ - $\mathrm{BuOH}(11.2 \mathrm{~mL}), 2-$ methyl-2-butene $(2.8 \mathrm{~mL})$ and tetra-aldehyde $53(52 \mathrm{mg}, 0.171 \mathrm{mmol})$ in the dark at room temperature. After overnight stirring, the mixture was acidified to $\mathrm{pH} 1-2$ and extracted with EtOAc $(5 \times 15 \mathrm{~mL})$. The combined organic layers were back extracted into saturated aqueous $\mathrm{NaHCO}_{3}(70 \mathrm{~mL})$. This solution was reacidified to $\mathrm{pH}$ 1-2 using $4 \mathrm{M} \mathrm{HCl}$ and extracted with EtOAc $(4 \times 40 \mathrm{~mL})$. These combined organic extracts were dried $\left(\mathrm{MgSO}_{4}\right)$, concentrated in vacuo and the residue further dried under vacuum overnight to afford the tetra-acid 54a (52 mg, 83\%) as a white solid, which was used directly in the subsequent step without further purification: ${ }^{1} \mathrm{H}$ NMR (400 MHz, DMSO-d $\left.d_{6}\right) \delta 11.96\left(b r s, 4 \mathrm{H}, \mathrm{CO}_{2} \mathrm{H}\right), 2.01\left(\mathrm{~s}, 8 \mathrm{H}, \mathrm{CH}_{2} \mathrm{CO}_{2} \mathrm{H}\right), 1.32$ (s, 12H, adamantane methylene); ${ }^{13} \mathrm{C}$ NMR $\left(100 \mathrm{MHz}\right.$, DMSO- $\left.d_{6}\right) \delta 172.8,47.7,45.6,34.2$.

Tetramethyl 2,2',2",2'"-(Adamantane-1,3,5,7-tetrayl)tetraacetate (54b). SOCl 2 (35 $\mu \mathrm{L}, 0.47$ mmol) was added slowly with stirring to tetra-acid $54 a(29 \mathrm{mg}, 0.079 \mathrm{mmol})$ and DMF $(1.2 \mu \mathrm{L}, 0.016 \mathrm{mmol})$ in $\mathrm{CH}_{2} \mathrm{Cl}_{2}(3 \mathrm{~mL})$ at 0 ${ }^{\circ} \mathrm{C}$. After stirring overnight at room temperature, all volatile materials were removed in vacuo and the crude tetra-acid chloride was allowed to dry under vacuum for an additional $4 \mathrm{~h}$ and was used in the subsequent step without any further purification. $\mathrm{MeOH}(6 \mathrm{~mL})$ was added with stirring to crude tetra-acid chloride at room temperature overnight, during which time the original cloudy mixture became a clear solution. The $\mathrm{MeOH}$ and $\mathrm{HCl}$ were removed in vacuo, the residue was dissolved in EtOAc $(20 \mathrm{~mL})$, washed with $\mathrm{H}_{2} \mathrm{O}(5 \mathrm{~mL})$, $5 \%$ aqueous $\mathrm{Na}_{2} \mathrm{CO}_{3}(5 \mathrm{~mL})$ and brine $(10 \mathrm{~mL})$, dried $\left(\mathrm{MgSO}_{4}\right)$ and concentrated in vacuo. The residue was chromatographed (hexanes : EtOAc, $4: 1$ ) to afford tetra-methyl ester 54b (14 $\mathrm{mg}, 42 \%$ over two steps) as colorless crystals: $\mathrm{mp} 80-82{ }^{\circ} \mathrm{C}$ (hexanes : EtOAc, $1: 1$ ); $R_{f} 0.31$ (hexanes : EtOAc, $2: 1$ ); IR (film) 2951, 2924, 2851, 1732, $1438 \mathrm{~cm}^{-1} ;{ }^{1} \mathrm{H}$ NMR $\left(400 \mathrm{MHz}, \mathrm{CDCl}_{3}\right) \delta 3.65\left(\mathrm{~s}, 12 \mathrm{H}, \mathrm{CO}_{2} \mathrm{CH}_{3}\right), 2.17\left(\mathrm{~s}, 8 \mathrm{H}, \mathrm{CH}_{2} \mathrm{CO}_{2} \mathrm{CH}_{3}\right), 1.40(\mathrm{~s}$, $12 \mathrm{H}$, adamantane methylene); ${ }^{13} \mathrm{C} \mathrm{NMR}\left(100 \mathrm{MHz}, \mathrm{CDCl}_{3}\right) \delta 171.6,51.2,47.1,45.2,34.3 ; \mathrm{MS}(\mathrm{EI}) \mathrm{m} / \mathrm{z} 424\left(\mathrm{M}^{+}\right)$; HRMS (EI) $m / z$ calc for $\mathrm{C}_{22} \mathrm{H}_{32} \mathrm{O}_{8} 424.2097$, found: 424.2083 .

Tetraethyl 4,4',4",4"'-(adamantane-1,3,5,7-tetrayl)tetrakis(3-oxobutanoate) (15a). Tetra-aldehyde 53 (238 $\mathrm{mg}, 0.78 \mathrm{mmol})$ in $\mathrm{CH}_{2} \mathrm{Cl}_{2}(6 \mathrm{~mL})$ was added with stirring to anhydrous $\mathrm{SnCl}_{2}(60 \mathrm{mg}, 0.31 \mathrm{mmol})$ and ethyl diazoacetate $(0.362 \mathrm{~mL}, 3.44 \mathrm{mmol})$ in $\mathrm{CH}_{2} \mathrm{Cl}_{2}(10 \mathrm{~mL})$ at $0{ }^{\circ} \mathrm{C}$ and the mixture allowed to warm up to room temperature. After $2 \mathrm{~h}$, the mixture was washed with brine $(15 \mathrm{~mL})$ and extracted with $\mathrm{CH}_{2} \mathrm{Cl}_{2}(3 \times 20 \mathrm{~mL})$. The organic extracts were dried $\left(\mathrm{MgSO}_{4}\right)$, concentrated in vacuo and the residue was chromatographed (hexanes : EtOAc, $2: 1$ ) to afford the tetra- $\beta$-keto ester 15 a (417 mg, 82\%) (3: 1 keto : enol forms) as a colorless oil: $R_{f}$ 0.46 (hexanes : EtOAc, 1 : 1); IR (film) 2983, 2905, 1744, 1714, $1633 \mathrm{~cm}^{-1}$; ${ }^{1} \mathrm{H}$ NMR (400 MHz, CDCl 3 ): (all keto 
form) $\delta 4.17$ (q, J $7.2 \mathrm{~Hz}, 8 \mathrm{H}, \mathrm{CO}_{2} \mathrm{CH}_{2} \mathrm{CH}_{3}$ ), 3.36 (m, 8H, $\mathrm{CH}_{2} \mathrm{CO}_{2} \mathrm{Et}$ ), 2.34 (m, 8H, $\mathrm{CH}_{2} \mathrm{COCH}_{2} \mathrm{CO}_{2} \mathrm{Et}$ ), 1.46-1.38 (m, $12 \mathrm{H}$, adamantane methylene), $1.26\left(\mathrm{t}, J 7.2 \mathrm{~Hz}, 12 \mathrm{H}, \mathrm{CO}_{2} \mathrm{CH}_{2} \mathrm{CH}_{3}\right)$; (all enol form) $\delta 12.06(\mathrm{~s}, 4 \mathrm{H}, \mathrm{HOC}=\mathrm{CH}), 4.86$ $(\mathrm{m}, 4 \mathrm{H}, \mathrm{HOC}=\mathrm{CH}), 4.17\left(\mathrm{q}, J 7.2 \mathrm{~Hz}, 8 \mathrm{H}, \mathrm{CO}_{2} \mathrm{CH}_{2} \mathrm{CH}_{3}\right), 1.97\left(\mathrm{~m}, 8 \mathrm{H}, \mathrm{CH}_{2} \mathrm{C}(\mathrm{OH})=\mathrm{CH}\right), 1.46-1.38(\mathrm{~m}, 12 \mathrm{H}$, adamantane methylene), $1.26\left(\mathrm{t}, J 7.2 \mathrm{~Hz}, 12 \mathrm{H}, \mathrm{CO}_{2} \mathrm{CH}_{2} \mathrm{CH}_{3}\right) ;{ }^{13} \mathrm{C} \mathrm{NMR} \mathrm{(100} \mathrm{MHz,} \mathrm{CDCl}_{3}$ ): (all keto form) $\delta 201.5$, 166.9, 61.3, 54.1, 51.3, 44.6, 34.9, 14.1; (all enol form) $\delta 175.6,172.4,91.7,59.9,48.5,45.3,34.7,14.2$; MS (EI) $\mathrm{m} / \mathrm{z} 648\left(\mathrm{M}^{+}\right.$); HRMS (EI) $\mathrm{m} / z$ calc for $\mathrm{C}_{34} \mathrm{H}_{48} \mathrm{O}_{12}$ 648.3146, found: 648.3145; Anal. Calc for $\mathrm{C}_{34} \mathrm{H}_{48} \mathrm{O}_{12}: \mathrm{C}_{1}$ 62.95; $H, 7.46$. Found: $C, 63.02 ; H, 7.52$.

Tetraethyl 4,4',4",4'"-(adamantane-1,3,5,7-tetrayl)tetrakis(2-diazo-3-oxobutanoate) (55a). Et ${ }_{3} \mathrm{~N}$ (1.04 mL, $7.44 \mathrm{mmol}$ ) was added dropwise with stirring to tetra- $\beta$-ketoester $15 \mathrm{a}$ (402 $\mathrm{mg}, 0.62 \mathrm{mmol}$ ) and 4acetamidobenzenesulfonyl azide (40) $(655 \mathrm{mg}, 2.73 \mathrm{mmol})$ in dry MeCN (15 mL) at $0{ }^{\circ} \mathrm{C}$ and the mixture allowed to warm up to room temperature. After $3 \mathrm{~h}$, the reaction mixture was concentrated in vacuo and the resultant solid was triturated with $\mathrm{Et}_{2} \mathrm{O}$ and hexanes $(1: 1)(100 \mathrm{~mL})$. The mixture was filtered, the filtrate was concentrated in vacuo and the residue was chromatographed (hexanes : EtOAc, $2: 1$ ) to afford the tetra-diazoester 55a (450 mg, 97\%) as a viscous oil: $R_{f} 0.51$ (hexanes : EtOAc, $1: 1$ ); IR (film) 2133, 1714, 1649, $1300 \mathrm{~cm}^{-1}$; ${ }^{1} \mathrm{H} \mathrm{NMR}\left(400 \mathrm{MHz}, \mathrm{CDCl}_{3}\right) \delta 4.23\left(\mathrm{q}, J 7.2 \mathrm{~Hz}, 8 \mathrm{H}, \mathrm{CO}_{2} \mathrm{CH}_{2} \mathrm{CH}_{3}\right), 2.68\left(\mathrm{~s}, 8 \mathrm{H}, \mathrm{CH}_{2} \mathrm{COC}=\mathrm{N}_{2}\right), 1.45$ (s, $12 \mathrm{H}$, adamantane methylene), $1.28\left(\mathrm{t}, J 7.2 \mathrm{~Hz}, 12 \mathrm{H}, \mathrm{CO}_{2} \mathrm{CH}_{2} \mathrm{CH}_{3}\right) ;{ }^{13} \mathrm{C} \mathrm{NMR}\left(100 \mathrm{MHz}, \mathrm{CDCl}_{3}\right) \delta 190.8,161.2,77.2$,

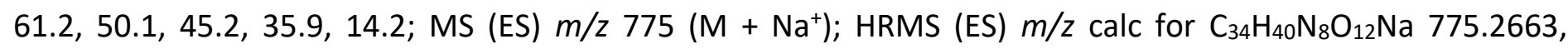
found: 775.2654 .

Tetra-tert-butyl 4,4',4",4'"-(Adamantane-1,3,5,7-tetrayl)tetrakis(3-oxobutanoate) (15b.) Tetra-aldehyde 53 (30 mg, $0.099 \mathrm{mmol}$ ) in $\mathrm{CH}_{2} \mathrm{Cl}_{2}(3 \mathrm{~mL})$ was added with stirring to anhydrous $\mathrm{SnCl}_{2}(7.5 \mathrm{mg}, 0.040 \mathrm{mmol})$ and tert-butyl diazoacetate $(0.060 \mathrm{~mL}, 0.43 \mathrm{mmol})$ in $\mathrm{CH}_{2} \mathrm{Cl}_{2}(2 \mathrm{~mL})$ at $0{ }^{\circ} \mathrm{C}$ and the mixture was allowed to warm up to room temperature. After $2 \mathrm{~h}$, the reaction was quenched with brine $(10 \mathrm{~mL})$ and the mixture was extracted with $\mathrm{CH}_{2} \mathrm{Cl}_{2}(3 \times 15 \mathrm{~mL})$. The organic extracts were dried $\left(\mathrm{MgSO}_{4}\right)$, concentrated in vacuo and the residue was chromatographed (hexanes : EtOAc, $4: 1$ ) to afford the tetra- $\beta$-keto ester 15b (61 mg, 81\%) (ca. 4 : 1 keto : enol forms) as a colorless oil: $R_{f} 0.41$ (hexanes : EtOAc, $2: 1$ ); IR (film) 2978, 2932, 1738, 1714, 1638 $\mathrm{cm}^{-1}$; ${ }^{1} \mathrm{H}$ NMR (400 MHz, $\mathrm{CDCl}_{3}$ ): (all keto form) $\delta 3.26$ (s, 8H, $\mathrm{CH}_{2} \mathrm{CO}_{2}{ }^{t} \mathrm{Bu}$ ), $2.33\left(\mathrm{~s}, 8 \mathrm{H}, \mathrm{CH}_{2} \mathrm{COCH}_{2} \mathrm{CO}_{2}{ }^{t} \mathrm{Bu}\right.$ ), 1.48 (s, $12 \mathrm{H}$, adamantane methylene), $1.45\left(\mathrm{~s}, 36 \mathrm{H}, \mathrm{C}\left(\mathrm{CH}_{3}\right)_{3}\right)$; (enol form) $\delta 12.19\left(\mathrm{~s}, 4 \mathrm{H}, \mathrm{C}(\mathrm{OH})=\mathrm{CHCO}_{2}{ }^{t} \mathrm{Bu}\right), 4.77(\mathrm{~s}$, $\left.4 \mathrm{H}, \mathrm{C}(\mathrm{OH})=\mathrm{CHCO}_{2}{ }^{t} \mathrm{Bu}\right), 1.94\left(\mathrm{~s}, 8 \mathrm{H}, \mathrm{CH}_{2} \mathrm{C}(\mathrm{OH})=\mathrm{CHCO}_{2}{ }^{t} \mathrm{Bu}\right), 1.48(\mathrm{~s}, 12 \mathrm{H}$, adamantane methylene), $1.45(\mathrm{~s}, 36 \mathrm{H}$, $\left.\mathrm{C}\left(\mathrm{CH}_{3}\right)_{3}\right) ;{ }^{13} \mathrm{C} \mathrm{NMR}\left(100 \mathrm{MHz}, \mathrm{CDCl}_{3}\right.$ ): (keto form) $\delta$ 202.0, 166.2, 81.8, 52.6, 48.6, 44.7, 34.7, 28.0; (enol form) $\delta$ 174.9, 172.4, 93.1, 81.9, 54.2, 45.2, 34.9, 28.3; MS (ES) $m / z 783$ (M+ Na+); HRMS (ES) $m / z$ calc for $\mathrm{C}_{42} \mathrm{H}_{64} \mathrm{O}_{12} \mathrm{Na}$ 783.4295, found: 783.4293; Anal. Calc for $\mathrm{C}_{42} \mathrm{H}_{64} \mathrm{O}_{12}$ : C, 66.29; $\mathrm{H}, 8.48$. Found: C, 66.33; $\mathrm{H}, 8.38$.

Tetra-tert-butyl 4,4',4",4'"-(Adamantane-1,3,5,7-tetrayl)tetrakis(2-diazo-3-oxobutanoate) (55b). Et ${ }_{3} \mathrm{~N}$ $(0.255 \mathrm{~mL}, 1.82 \mathrm{mmol})$ was added dropwise with stirring to tetra- $\beta$-keto ester $15 \mathrm{~b}(115 \mathrm{mg}, 0.151 \mathrm{mmol})$ and 4-acetamidobenzenesulfonyl azide (40) $(160 \mathrm{mg}, 0.666 \mathrm{mmol})$ in dry $\mathrm{MeCN}(10 \mathrm{~mL})$ at $0{ }^{\circ} \mathrm{C}$ was added and the mixture was allowed to warm up to room temperature. After stirring overnight, the reaction mixture was concentrated in vacuo and the resultant solid was triturated with $\mathrm{Et}_{2} \mathrm{O}$ and hexanes (1:1) (80 $\left.\mathrm{mL}\right)$, the mixture was filtered, and the filtrate was concentrated in vacuo. The residue was chromatographed (hexanes : EtOAc, $4: 1$ ) to afford tetra-diazo-tert-butyl ester $\mathbf{5 5 b}(130 \mathrm{mg}, 99 \%)$ as a viscous oil: $R_{f} 0.57$ (hexanes : EtOAc, $\left.2: 1\right)$; IR (film) 2979, 2930, 2130, 1712, 1645, $1310 \mathrm{~cm}^{-1} ;{ }^{1} \mathrm{H}$ NMR $\left(400 \mathrm{MHz}, \mathrm{CDCl}_{3}\right) \delta 2.67\left(\mathrm{~s}, 8 \mathrm{H}, \mathrm{CH}_{2} \mathrm{C}(\mathrm{O}) \mathrm{C}=\mathrm{N}_{2}\right), 1.48$ (s, 36H, tert-butyl), 1.46 (s, $12 \mathrm{H}$, adamantane methylene); ${ }^{13} \mathrm{C} N M R\left(100 \mathrm{MHz}, \mathrm{CDCl}_{3}\right) \delta 191.2,160.4,82.9$, 
78.0, 50.2, 45.2, 35.9, 28.2; MS (ES) $m / z 887\left(\mathrm{M}+\mathrm{Na}^{+}\right.$); HRMS (ES) $\mathrm{m} / z$ calc for $\mathrm{C}_{42} \mathrm{H}_{56} \mathrm{~N}_{8} \mathrm{O}_{12} \mathrm{Na}_{887.3915}$, found: 887.3923; Anal. Calc for $\mathrm{C}_{42} \mathrm{H}_{56} \mathrm{~N}_{8} \mathrm{O}_{12}$ : C, 58.32; $\mathrm{H}, 6.53 ; \mathrm{N}, 12.96$. Found: $\mathrm{C}, 58.42 ; \mathrm{H}, 6.47 ; \mathrm{N}, 12.86$.

2-(1-Adamantane)acetyl chloride. ${ }^{50}$ Freshly distilled $\mathrm{SOCl}_{2}(12 \mathrm{~mL})$ was added to 2-(1-adamantane)acetic acid $(1.50 \mathrm{~g}, 7.73 \mathrm{mmol})$ in a flame-dried flask. The mixture was heated to reflux with vigorous stirring for $5 \mathrm{~h}$, when the excess thionyl chloride was removed in vacuo. $\mathrm{PhH}(15 \mathrm{~mL})$ was added and was subsequently removed in vacuo to leave a light yellow oil, which was stored under vacuum overnight to leave crude 2-(1adamantane)acetyl chloride (1.65 g, 99\%) as a light yellow oil: IR (film) 2904, 2850, 1797, $1451 \mathrm{~cm}^{-1} ;{ }^{1} \mathrm{H} \mathrm{NMR}$ (300 MHz, $\left.\mathrm{CDCl}_{3}\right) \delta 2.70\left(\mathrm{~s}, 2 \mathrm{H}, \mathrm{CH}_{2} \mathrm{COCl}\right.$ ), 1.99 (s, 3H, adamantane methine), 1.74-1.67 (m, 12H, adamantane methylene); ${ }^{13} \mathrm{C}$ NMR $\left(75 \mathrm{MHz}, \mathrm{CDCl}_{3}\right) \delta 170.9,60.7,41.6,36.4,34.0,28.3$.

1-Diazo-3-(1-adamantyl)-2-propanone. ${ }^{48} \mathrm{~N}$-Nitroso- $\mathrm{N}$-methyl urea $(3.0 \mathrm{~g}, 28.6 \mathrm{mmol})$ was added in small portions with stirring to aqueous $\mathrm{KOH}(50 \% ; 8 \mathrm{~mL})$ and $\mathrm{Et}_{2} \mathrm{O}(20 \mathrm{~mL})$ at $0{ }^{\circ} \mathrm{C}$. After $15 \mathrm{~min}$, the bright yellow ethereal solution of $\mathrm{CH}_{2} \mathrm{~N}_{2}$ was carefully decanted and maintained at $0{ }^{\circ} \mathrm{C}$. 2-(1-Adamantane)acetyl chloride $(1.5 \mathrm{~g}, 7.04 \mathrm{mmol})$ in $\mathrm{Et}_{2} \mathrm{O}(10 \mathrm{~mL})$ was added dropwise with stirring to the ice-cold $\mathrm{CH}_{2} \mathrm{~N}_{2}$ solution. After $2 \mathrm{~h}$ at $0{ }^{\circ} \mathrm{C}$ and room temperature overnight, removal of solvent in vacuo left the title diazo-ketone (1.54 $\mathrm{g}$, quantitative yield) as a yellow oil: $R_{f} 0.42$ (hexanes : EtOAc, $4: 1$ ); IR (film) 2902, 2847, 2099, $1631,1354 \mathrm{~cm}^{-1}$; ${ }^{1} \mathrm{H}$ NMR (300 MHz, CDCl 3 ) $\delta 5.19\left(\mathrm{~s}, 1 \mathrm{H}, \mathrm{COCHN}\right.$ ), 2.05 (s, 2H, $\left.\mathrm{CH}_{2} \mathrm{CO}\right), 1.97$ (s, 3H, adamantane methine), 1.63 (s, $12 \mathrm{H}$, adamantane methylene); $\mathrm{MS}\left(\mathrm{Cl}, \mathrm{NH}_{3}\right) \mathrm{m} / z 219\left(\mathrm{M}+\mathrm{H}^{+}\right) ; \mathrm{HRMS}\left(\mathrm{Cl}, \mathrm{NH}_{3}\right) \mathrm{m} / z$ calc for $\mathrm{C}_{13} \mathrm{H}_{19} \mathrm{~N}_{2} \mathrm{O}(\mathrm{M}+$ $\mathrm{H}^{+}$) 219.1497, found: 219.1496.

\section{Octahydro-3a,7:5,9-dimethanocyclopenta[8]annulen-2(3H)-one $\quad$ (49). ${ }^{48} \quad$ 1-Diazo-3-(1-adamantyl)-2-} propanone 1-(3-Diazo-2-oxo-1-propyl)-adamantane ${ }^{48}(1.55 \mathrm{~g}, 7.11 \mathrm{mmol})$ in PhMe $(40 \mathrm{~mL})$ was added over $5 \mathrm{~h}$ via syringe pump to toluene $(160 \mathrm{~mL})$ containing $\mathrm{CuSO}_{4}(320 \mathrm{mg}, 2.0 \mathrm{mmol})$ at reflux. The mixture was subsequently heated under reflux for an additional $2 \mathrm{~h}$, cooled down to room temperature and filtered. The filtrate was sequentially washed with $\mathrm{H}_{2} \mathrm{O}(50 \mathrm{~mL}), 5 \mathrm{M}$ aqueous $\mathrm{NaOH}(50 \mathrm{~mL}), \mathrm{H}_{2} \mathrm{O}(50 \mathrm{~mL})$ and brine $(50 \mathrm{~mL})$, dried $\left(\mathrm{MgSO}_{4}\right)$ filtered and evaporation in vacuo. The residual thick light brown oil was chromatographed (hexanes : EtOAc, $50: 1$ ) to give the cyclopentanone 49 (632 mg, 47\% over 3 steps), which was identical with the material previously prepared. ${ }^{48}$

4,5,6,7,8,9-Hexahydro-3a,7:5,9-dimethanocyclopenta[8]annulen-2(3H)-one (57). $\mathrm{Me} 3 \mathrm{SiCl}_{\text {(3.74 } \mathrm{mL}, 29.2}$ $\mathrm{mmol})$ and cyclopentanone $49(554 \mathrm{mg}, 2.92 \mathrm{mmol})$ in THF $(6 \mathrm{~mL})$ were added sequentially dropwise with stirring to lithium 2,2,6,6-tetramethylpiperidide $(13.1 \mathrm{mmol})$, prepared from 2,2,6,6-tetramethylpiperidine $(2.46 \mathrm{~mL}, 14.6 \mathrm{mmol})$ and $n$-BuLi $(1.6 \mathrm{M}$ in hexanes, $8.2 \mathrm{~mL}, 13.1 \mathrm{mmol})$ in THF $(5 \mathrm{~mL})$, at $-78^{\circ} \mathrm{C}$. After a further $20 \mathrm{~min}$ at $-78{ }^{\circ} \mathrm{C}, \mathrm{Et}_{3} \mathrm{~N}(6.3 \mathrm{~mL})$ was added, and the mixture was allowed to warm to room temperature during a period of $1 \mathrm{~h}$. $\mathrm{Et}_{2} \mathrm{O}(50 \mathrm{~mL})$ was added, and the organic solution was washed with $\mathrm{H}_{2} \mathrm{O}(20 \mathrm{~mL})$ and brine $(20 \mathrm{~mL})$, dried $\left(\mathrm{MgSO}_{4}\right)$, concentrated in vacuo and the remaining tetramethylpiperidine removed under vacuum. $\mathrm{Pd}(\mathrm{OAc})_{2}(643 \mathrm{mg}, 2.86 \mathrm{mmol}$ ) was added to residue of silyl enol ethers in dry MeCN (10 mL) and the mixture stirred overnight at room temperature. The mixture was filtered through a short pad of Celite, eluting with $\mathrm{Et}_{2} \mathrm{O}$ and the organic phase was washed with saturated aqueous $\mathrm{NH}_{4} \mathrm{Cl}(10 \mathrm{~mL})$, dried $\left(\mathrm{MgSO}_{4}\right)$, concentrated in vacuo and the residue chromatographed (hexanes : EtOAc, $15: 1$ to $10: 1$ ) to afford the cyclopentenone 57 (125 mg, 23\%) and recovered starting material 49 (178 mg, 32\%). The enone 57 was obtained as a colorless oil: $R_{f} 0.29$ (hexanes : EtOAc, $4: 1$ ); IR (film) 2917, 2851, 1703, $1626 \mathrm{~cm}^{-1} ;{ }^{1} \mathrm{H} \mathrm{NMR}(300$ $\left.\mathrm{MHz}, \mathrm{CDCl}_{3}\right) \delta 5.73(\mathrm{~s}, 1 \mathrm{H}, \mathrm{COCH}=\mathrm{C}), 3.06\left(\mathrm{~s}, 2 \mathrm{H}, \mathrm{CH}_{2} \mathrm{CO}\right), 2.10-2.01(\mathrm{~m}, 7 \mathrm{H}$, adamantane methine and 
methylene), 1.84-1.82 (m, 4H, adamantane methylene), $1.66\left(\mathrm{~m}, 2 \mathrm{H}\right.$, adamantane methylene); ${ }^{13} \mathrm{C} \mathrm{NMR}(75$ $\left.\mathrm{MHz}_{2} \mathrm{CDCl}_{3}\right) \delta 208.5,192.3,121.5,49.4,45.2,43.3,38.2,35.7,35.2,28.7 ; \mathrm{MS}$ (EI) $\mathrm{m} / \mathrm{z} 188$ (M ${ }^{+}$); HRMS (EI) $\mathrm{m} / z$ calc for $\mathrm{C}_{13} \mathrm{H}_{16} \mathrm{O}\left(\mathrm{M}^{+}\right)$188.1201, found: 188.1201 .

2,3,4,5,6,7,8,9-Octahydro-3a,7:5,9-dimethanocyclopenta[8]annulen-2-ol (58). DIBAI-H in hexanes (1.0 M; $0.59 \mathrm{~mL}, 0.59 \mathrm{mmol}$ ) was added dropwise with stirring to cyclopentenone 57 (55 mg, $0.29 \mathrm{mmol})$ in dry THF (5 $\mathrm{mL}$ ) at $-78^{\circ} \mathrm{C}$. After a further $30 \mathrm{~min}$ at $-78^{\circ} \mathrm{C}$, saturated aqueous $\mathrm{NH}_{4} \mathrm{Cl}(0.16 \mathrm{~mL}), \mathrm{Et}_{2} \mathrm{O}(10 \mathrm{~mL})$, and silica gel (200 mg) were added and the mixture was stirred vigorously and allowed to warm up to room temperature. The mixture was filtered through a short pad of anhydrous $\mathrm{MgSO}_{4}$ and the solids were leached with EtOAc. The combined organic phases were rotary evaporated and the residue chromatographed (hexanes : EtOAc, 8 : 1) to give the cyclopentenol 58 (50 mg, 90\%) as a colorless oil: $R_{f} 0.28$ (hexanes : EtOAc, $\left.4: 1\right)$; IR (film) 3331 broad, 2902, 2847, $1666 \mathrm{~cm}^{-1}$; ${ }^{1} \mathrm{H}$ NMR $\left(400 \mathrm{MHz}, \mathrm{C}_{6} \mathrm{D}_{6}\right) \delta 5.25$ (d, J $2.0 \mathrm{~Hz}, 1 \mathrm{H}, \mathrm{CH}=\mathrm{C}$ ), 4.83 (ddd, J 7.8, 3.9, 2.0 $\mathrm{Hz}, 1 \mathrm{H}, \mathrm{CHOH}), 2.61\left(\mathrm{~m}, 1 \mathrm{H}, \mathrm{CH}_{2} \mathrm{CHOH}\right), 2.31\left(\mathrm{~m}, 1 \mathrm{H}, \mathrm{CH}_{2} \mathrm{CHOH}\right), 1.91$ (dd, J 14.1, 7.8 Hz, 1H, CH=CCH), 1.86-1.37 (m, 12H, adamantane); ${ }^{13} \mathrm{C}$ NMR (100 MHz, $\left.\mathrm{C}_{6} \mathrm{D}_{6}\right) \delta 157.4,118.0,76.3,48.4,46.9,46.3,46.2,38.7$, $36.7,33.9,30.2,30.0,29.8$; the product did not exhibit a molecular ion in the MS.

4,5,6,7,8,9-Hexahydro-3a,7:5,9-dimethanocyclopenta[8]annulene (59). Allylic alcohol 58 (48 mg, $0.25 \mathrm{mmol}$ ) was dissolved in $\mathrm{CDCl}_{3}(2 \mathrm{~mL})$. After $2 \mathrm{~h}, \mathrm{CDCl}_{3}$ was carefully removed in vacuo and the residue was chromatographed (hexanes only) to afford adamantanocyclopentadiene 59 (40 $\mathrm{mg}, \mathbf{8 9 \%}$ ) as a colorless and volatile oil: $R_{f} 0.76$ (hexanes : EtOAc, 15 : 1); IR (film) 2914, $\left.2848 \mathrm{~cm}^{-1} ;{ }^{1} \mathrm{H} \mathrm{NMR} \mathrm{(300} \mathrm{MHz,} \mathrm{CDCl}\right)_{3} \delta 6.41$ (d, J 5.0 $\mathrm{Hz}, 1 \mathrm{H}, \mathrm{CH}=\mathrm{CHCH}=\mathrm{C}), 6.30(\mathrm{~d}, J 5.0 \mathrm{~Hz}, 1 \mathrm{H}, \mathrm{CH}=\mathrm{CHCH}=\mathrm{C}), 5.82$ (s, 1H, CH=CHCH=C), 3.06 (apparent s, 1H, $\mathrm{CH}=\mathrm{CHCH}=\mathrm{CCH}$ ), 2.15 (apparent d, J $12.0 \mathrm{~Hz}, 2 \mathrm{H}$, adamantane), 2.01 (apparent s, 2H, adamantane), 1.93 (apparent d, J $12.0 \mathrm{~Hz}, 2 \mathrm{H}$, adamantane), 1.78 (apparent s, 2H, adamantane), 1.51 (apparent d, J 11.5 Hz, 2H, adamantane), 1.12 (apparent $\mathrm{d}, J 11.5 \mathrm{~Hz}, 2 \mathrm{H}$, adamantane); ${ }^{13} \mathrm{C} \mathrm{NMR}\left(75 \mathrm{MHz}, \mathrm{CDCl}_{3}\right) \delta$ 160.6, 142.7, 130.0, 113.8, 53.0, 41.2, 39.3, 36.1, 33.8, 28.1; MS (EI) $\mathrm{m} / z 172\left(\mathrm{M}^{+}\right.$); HRMS (EI) $\mathrm{m} / z$ calc for $\mathrm{C}_{13} \mathrm{H}_{16}\left(\mathrm{M}^{+}\right)$172.1252, found: 172.1253 .

\section{( \pm )-(3aR,3bR,4S,6R,8S,9aR,10S,10aR)-4,5,6,7,8,9,10,10a-Octahydro-1H-3b,10-etheno-4,8:6,9a-dimethano-} cycloocta[3,4]cyclopenta[1,2-c]furan-1,3(3aH)-dione (61). Diene 59 (15 $\mathrm{mg}, 0.087 \mathrm{mmol}$ ) and maleic anhydride $(60)(11 \mathrm{mg}, 0.13 \mathrm{mmol})$ in $\mathrm{CH}_{2} \mathrm{Cl}_{2}(0.5 \mathrm{~mL})$ and $\mathrm{CHCl}_{3}(1 \mathrm{~mL})$ were allowed to stand for $21 \mathrm{~h}$ at room temperature. $\mathrm{CHCl}_{3}$ and $\mathrm{CH}_{2} \mathrm{Cl}_{2}$ were removed in vacuo and the residue was chromatographed (hexanes : $\mathrm{Et}_{2} \mathrm{O}$ ) to give the Diels-Alder adduct 61 ( $5 \mathrm{mg}, 23 \%$ ) as a light yellow oil; $R_{f} 0.40$ (hexanes : EtOAc, 4:1); IR (film) 2912, 2854, 2359, 1856, $1776 \mathrm{~cm}^{-1}$; ${ }^{1} \mathrm{H}$ NMR: (300 MHz, CDCl 3 ) $\delta 6.25$ (d, J $5.7 \mathrm{~Hz}, 1 \mathrm{H}$ ), 6.15 (dd, J 5.7, $2.8 \mathrm{~Hz}$, 1H), 3.91 (d, J $7.7 \mathrm{~Hz}, 1 \mathrm{H}), 3.70(\mathrm{dd}, \mathrm{J} 7.6,4.5 \mathrm{~Hz}, 1 \mathrm{H}), 3.10(\mathrm{~m}, 1 \mathrm{H}), 2.55(\mathrm{~s}, 1 \mathrm{H}), 2.21-2.17(\mathrm{~m}, 1 \mathrm{H}), 2.06-2.02$ $(\mathrm{m}, 2 \mathrm{H}), 1.90-1.62(\mathrm{~m}, 6 \mathrm{H}), 1.34-1.26(\mathrm{~m}, 3 \mathrm{H}) ;{ }^{13} \mathrm{C} \mathrm{NMR:}\left(75 \mathrm{MHz}, \mathrm{CDCl}_{3}\right) \delta 172.3,171.8,138.8,133.1,63.1$, 61.3, 53.5, 47.8, 46.4, 38.2, 35.1, 33.7, 31.9, 29.7, 28.4, 28.2, 27.8; MS (EI) $\mathrm{m} / z 270$ (M ${ }^{+}$); HRMS (EI) $\mathrm{m} / z$ calc for $\mathrm{C}_{17} \mathrm{H}_{18} \mathrm{O}_{3}\left(\mathrm{M}^{+}\right)$270.1256, found 270.1256 .

(2,3,4,5,6,7,8,9-Octahydro-3a,7:5,9-dimethanocyclopenta[8]annulen-2-yl) 3-(4,5,6,7,8,9-hexahydro-3a,7:5,9dimethanocyclopenta[8]annulene) (63). Tris(p-bromophenyl)aminium hexachloroantimonate (62) (57 mg, $0.070 \mathrm{mmol}$ ) was added with stirring to adamantanocyclopentadiene 59 (120 mg, $0.70 \mathrm{mmol})$ in $\mathrm{CH}_{2} \mathrm{Cl}_{2}(3.5$ $\mathrm{mL}$ ) at $0{ }^{\circ} \mathrm{C}$. After $2.5 \mathrm{~h}$, reaction was quenched with excess methanolic sodium methoxide and the mixture was diluted with excess $\mathrm{CH}_{2} \mathrm{Cl}_{2}$. The organic phase was washed with $\mathrm{H}_{2} \mathrm{O}(3 \times 10 \mathrm{~mL})$ and brine $(10 \mathrm{~mL})$, dried $\left(\mathrm{MgSO}_{4}\right)$, concentrated in vacuo and the residue chromatographed (hexanes only) to give the substituted 
cyclopentadiene dimer 63 (48 mg, 40\%) as a colorless oil: $R_{f} 0.78$ (hexanes : EtOAc, 15 : 1); IR (film) 2904, 2846, $1445 \mathrm{~cm}^{-1}$; UV-Vis (hexanes) $\lambda_{\max }(\log \varepsilon) 262(3.76) \mathrm{nm} ;{ }^{1} \mathrm{H}$ NMR $\left(500 \mathrm{MHz}, \mathrm{C}_{6} \mathrm{D}_{6}\right) \delta 6.30\left(\mathrm{~m}, 1 \mathrm{H}, \mathrm{H}_{\mathrm{A}}\right), 5.93(\mathrm{~d}, J$ $\left.1.9 \mathrm{~Hz}, 1 \mathrm{H}, \mathrm{H}_{\mathrm{B}}\right), 5.21\left(\mathrm{~d}, J 2.0 \mathrm{~Hz}, 1 \mathrm{H}, \mathrm{H}_{\mathrm{C}}\right), 3.72\left(\mathrm{~m}, 1 \mathrm{H}, \mathrm{H}_{\mathrm{E}}\right), 2.98\left(\mathrm{~m}, 1 \mathrm{H}, \mathrm{H}_{\mathrm{F}}\right), 2.75\left(\mathrm{~m}, 1 \mathrm{H}, \mathrm{H}_{\mathrm{D}}\right), 2.10-1.20(\mathrm{~m}, 26 \mathrm{H}$, adamantane and $\left.\mathrm{H}_{\mathrm{G}}\right) ;{ }^{13} \mathrm{CNMR}\left(125 \mathrm{MHz}, \mathrm{C}_{6} \mathrm{D}_{6}\right) \delta 162.2,157.9,153.0,123.9,117.4,114.6,53.3,47.3,47.1$, 46.4, 45.9, 41.9, 41.5, 41.4, 40.4, 39.8, 39.5, 38.7, 37.0, 36.5, 34.2, 34.1, 30.39, 30.36, 28.74, 28.70; MS (EI) m/z $344\left(\mathrm{M}^{+}\right)$; HRMS (EI) $\mathrm{m} / z$ calc for $\mathrm{C}_{26} \mathrm{H}_{32}\left(\mathrm{M}^{+}\right)$344.2504, found: 344.2503 .

\section{Acknowledgements}

We thank GlaxoSmithKline for the endowment (to A.G.M.B) and the EPSRC for an EPSRC-BP Dorothy Hodgkin Postgraduate Award (to T.Q.).

\section{Supplementary Material}

Copies of the single crystal X-ray crystallographic structures of tetraol $\mathbf{2 1}$ and tetra-((hydroxymethyl)cyclopropyl)-adamantane 35, their CIF files and NMR spectra for the dimer 63 are provided in the Supplementary Material.

\section{References}

1. Fuchs, P. L. Tetrahedron, 2001, 57, 6855. https://doi.org/10.1016/S0040-4020(01)00474-4

2. Barrett, A. G. M.; Hamprecht, D.; White, A. J. P.; Williams, D. J. J. Am. Chem. Soc. 1996, 118, 7863. https://doi.org/10.1021/ja961399n

3. Charette, A. B.; Lebel, H. J. Am. Chem. Soc. 1996, 118, 10327. https://doi.org/10.1021/ja9619420

4. Vigneron, J. P.; Dhaenens, M.; Horeau, A. Tetrahedron, 1973, 29, 1055. https://doi.org/10.1016/0040-4020(73)80060-2

5. Stetter, H.; Krause, M. Justus Liebigs Ann. Chem. 1968, 717, 60. https://doi.org/10.1002/jlac.19687170106

6. Lee, G. S.; Bashara, J. N.; Sabih, G.; Oganesyan, A.; Godjoian, G.; Duong, H. M.; Marinez, E. R.; Gutierrez, C. G. Org. Lett 2004, 6, 1705.

7. McCullagh, E.; Bernales, S.; Hung, D. WO Patent Appl. 2017/19833 A1, 2017.

8. Koellner, C.; Togni, A. Canad. J. Chem. 2001, 79, 1762. https://doi.org/10.1139/v01-145

9. Newkome, G. R.; Moorefield, C. N. US Patent Appl. 2003/97019 A1; (2003). https://doi.org/10.1002/ejoc.200300238

10. Dave, P. R.; Duddu, R.; Yang, K.; Damavarapu, R.; Gelber, N.; Surapaneni, R.; Gilardi, R. Tetrahedron Lett. 2004, 45, 2159. https://doi.org/10.1016/i.tetlet.2004.01.037 
11. Braun, D.; Keller, C.-C.; Roth, M. D.; Schartel, B.; Voigt, M.; Wendorff, J. H. J. Prakt. Chem. Chem.-Zeitung 1997, 339, 708.

https://doi.org/10.1002/prac.199733901129

12. Pannier, N.; Maison, W. Eur. J. Org. Chem. 2008, 1278.

https://doi.org/10.1002/ejoc.200701003

13. Nasr, K.; Pannier, N.; Frangioni, J. V.; Maison, W. J. Org. Chem. 2008, 73, 1056.

https://doi.org/10.1021/jo702310g

14. Landa; K. Coll. Czech. Chem. Commun. 1959, 24, 4004.

https://doi.org/10.1135/cccc19590093

15. Wadsworth, H. J.; Newington, I. M. WO Patent Application 2009/021948 A1 (2009).

16. Boldog, I.; Domasevitch, K. V.; Sanchiz, J.; Mayer, P.; Janiak, C . Dalton Trans. 2014, 43, 12590. https://doi.org/10.1039/C4DT01022A

17. Kozhushkov, S. I.; Yufit, D. S.; Boese, R.; Blaeser, D.; Schreiner, P. R.; De Meijere, A. Eur. J. Org. Chem. 2005, 1409 and references therein.

https://doi.org/10.1002/ejoc.200400731

18. Naemura, K.; Hokura, Y.; Nakazaki, M. Tetrahedron, 1986, 42, 1763 and references therein.

19. Plietzsch, O.; Schilling, C. I.; Nieger, M.; Muller, T.; Bräse, S. Tetrahedron: Asymmetry 2010, 1474. https://doi.org/10.1016/j.tetasy.2010.05.018

20. Pop, L.; Golban, M. L.; Hādade, N. D.; Socaci, C.; Grosu, I. Synthesis, 2015, 47, 2799. https://doi.org/10.1055/s-0034-1378782

21. Plietzsch, O.; Schilling, C. I.; Tolev, M.; Nieger, M.; Richert, C.; Muller, T.; Braese, S. Org. Biomol. Chem. 2009, 4734.

https://doi.org/10.1039/b912189g

22. Schilling, C. I.; Plietzsch, O.; Nieger, M.; Muller, T.; Braese, S. Eur. J. Org. Chem. 2011, 1743. https://doi.org/10.1002/ejoc.201001567

23. Lee, H.; Kim, H.; Choi, T. J.; Park, H. W.; Chang, J. Y. Chem. Commun. 2015, 51, 9805. https://doi.org/10.1039/C5CC02269J

24. Grigg, R.; Elboray, E. E.; Aly, M. F.; Abbas-Temirek, H. H.; Chem. Commun. 2012, 48, 11504. https://doi.org/10.1039/c2cc35054h

25. Valera, S.; Taylor, J. E.; Daniels, D. S. B.; Dawson, D.I. M.; Athukorala Arachchige, K. S.; Ashbrook, S. E.; Slawin, A. M. Z.; Bode, B. E. J. Org. Chem. 2014, 79, 8313.

https://doi.org/10.1021/jo5015678

26. Zulfiqar, S.; Mantione, D.; El Tall, O.; Sarwar, M. I.; Ruipérez, F.; Rothen-berger, A.; Mecerreyes, D. J. Mater. Chem. A 2016, 4, 8190. https://doi.org/10.1039/C6TA01457G

27. Petter, R. C.; Barsoum, J. G.; Kumaravel, G.; Bair, K. W. US Pat. Appl. 2019/0194150 A1 (2019).

28. Head, N. J.; Surya Prakash, G.K.; Bashir-Hashemi, A.; Olah, G. A. J. Am. Chem. Soc. 1995, 117, 12005. https://doi.org/10.1021/ja00150a017

29. Schwertfeger, H.; Fokin, A. A.; Schreiner, P. R. Angew. Chem. Int. Ed. 2008, 47, 1022. https://doi.org/10.1002/anie.200701684

30. Bashir-Hashemi, A.; Li, J. Tetrahedron Lett. 1995, 36, 1233.

https://doi.org/10.1016/0040-4039(95)00023-6

31. Heagy, M. D.; Wang, Q.; Olah, G. A.; Prakash, G. K. S. J. Org. Chem. 1995, 60, 7351. https://doi.org/10.1021/jo00127a049 
32. Still, W. C.; Gennari, C. Tetrahedron Lett. 1983, 24, 4405.

https://doi.org/10.1016/S0040-4039(00)85909-2

33. Friedrich, J.; Dolg, M.; Gansäuer, A.; Geich-Gimbel, D.; Lauterbach, T. J. Am. Chem. Soc. 2005, $127,7071$. https://doi.org/10.1021/ja050268w

34. Molander, G. A.; Harring, L. S. J. Org. Chem. 1989, 54, 3525.

https://doi.org/10.1021/jo00276a008

35. Charette, A. B.; Prescott, S.; Brochu, C. J. Org. Chem. 1995, 60, 1081.

https://doi.org/10.1021/jo00109a049

36. Fulton, J. R.; Aggarwal, V. K.; de Vicente, J. Eur. J. Org. Chem. 2005, 1479.

https://doi.org/10.1002/ejoc.200400700

37. Luly, J. R.; Dellaria, J. F.; Plattner, J. J.; Soderquist, J. L.; Yi, N. J. Org. Chem. 1987, 52, 1487.

https://doi.org/10.1021/jo00384a020

38. Holmquist, C. R.; Roskamp, E. J. J. Org. Chem. 1989, 54, 3258.

https://doi.org/10.1021/jo00275a006

39. Davies, J. R.; Kane, P. D.; Moody, C. J. Tetrahedron 2004, 60, 3967.

https://doi.org/10.1016/j.tet.2004.03.037

40. Majerski, Z.; Škare, D.; Vulić, L. Synthetic Communications 1986, $16,51$.

https://doi.org/10.1080/00397918608057687

41. Krapcho, A. P.; Weimaster, J. F.; Eldridge, J. M.; Jangnen Jr., E. G. E.; Lovey, A. J.; Stephens, W. P. J. Org. Chem. 1978, 43, 138.

https://doi.org/10.1021/jo00395a032

42. Ōsawa, E.; Tahara, Y.; Togashi, A.; lizuka, T.; Tanaka, N.; Tadayoshi, K.; Farcasiu, D.; Kent, G. J.; Engler, E. M.; von R. Schleyer, P. J. Org. Chem. 1982, 47, 1923.

43. Kraus, G. A.; Roth, B. J. Org. Chem. 1980, 45, 4825 and references therein.

https://doi.org/10.1021/jo01312a004

44. Reynolds, D. W.; Lorenz, K. T.; Chiou, H.-S.; Bellville, D. J.; Pabon, P. A.; Bauld, N. L. J. Am. Chem. Soc. 1987, 109,4960 and references therein.

https://doi.org/10.1021/ja00250a033

45. Mironov, V. A.; Ivanov, A. P.; Akhrem, A. A. Bull. Acad. Sci. USSR Div. Chem. Sci. 1973, 22, 346.

https://doi.org/10.1007/BF00850989

46. Ohno, M.; Ishizaki, K.; Eguchi, S. J. Org. Chem. 1988, 53, 1285.

https://doi.org/10.1021/jo00241a030

47. Bormasheva, K. M.; Nechaeva, O. N.; Moiseev, I. K. Russ. J. Org. Chem. 2008, 44, 1760.

https://doi.org/10.1134/S1070428008120063

48. Chakrabarti, J. K.; Szinai, S. S.; Todd, A. J. Chem. Soc. C 1970, 1303.

https://doi.org/10.1039/j39700001303

49. Anderson, J. C.; Denton, R. M.; Hickin, H. G.; Wilson, C. Tetrahedron 2004, 60, 2327.

https://doi.org/10.1016/i.tet.2004.01.021

50. Butov, G. M.; Burmistrov, V. V.; Pitushkin, D. A. Russ J. Org. Chem. 2017, 53, 673.

https://doi.org/10.1134/S1070428017050050 